\title{
Clinical applications of molecular cytogenetics in astrocytoma grade II
}

Citation for published version (APA):

Wessels, P. H. (2003). Clinical applications of molecular cytogenetics in astrocytoma grade II. [Doctoral Thesis, Maastricht University]. Universiteit Maastricht. https://doi.org/10.26481/dis.20031010pw

Document status and date:

Published: 01/01/2003

DOI:

10.26481/dis.20031010pw

Document Version:

Publisher's PDF, also known as Version of record

\section{Please check the document version of this publication:}

- A submitted manuscript is the version of the article upon submission and before peer-review. There can be important differences between the submitted version and the official published version of record.

People interested in the research are advised to contact the author for the final version of the publication, or visit the DOI to the publisher's website.

- The final author version and the galley proof are versions of the publication after peer review.

- The final published version features the final layout of the paper including the volume, issue and page numbers.

Link to publication

\footnotetext{
General rights rights.

- You may freely distribute the URL identifying the publication in the public portal. please follow below link for the End User Agreement:

www.umlib.nl/taverne-license

Take down policy

If you believe that this document breaches copyright please contact us at:

repository@maastrichtuniversity.nl

providing details and we will investigate your claim.
}

Copyright and moral rights for the publications made accessible in the public portal are retained by the authors and/or other copyright owners and it is a condition of accessing publications that users recognise and abide by the legal requirements associated with these

- Users may download and print one copy of any publication from the public portal for the purpose of private study or research.

- You may not further distribute the material or use it for any profit-making activity or commercial gain

If the publication is distributed under the terms of Article $25 \mathrm{fa}$ of the Dutch Copyright Act, indicated by the "Taverne" license above, 
CLINICAL APPLICATIONS OF MOLECULAR CYTOGENETICS IN ASTROCYTOMA GRADE ॥ 



\title{
CLINICAL APPLICATIONS OF MOLECULAR \\ CYTOGENETICS IN ASTROCYTOMA GRADE ॥
}

\author{
PROEFSCHRIFT \\ ter verkrijging van de graad van doctor aan \\ de Universiteit Maastricht, \\ op gezag van de Rector Magnificus, \\ Prof. Dr. A.C. Nieuwenhuijzen Kruseman \\ volgens het besluit van het College van Decanen, \\ te verdedigen \\ op vrijdag 10 oktober 2003 om 14.00 uur \\ door
}

Peter $\mathrm{H}$. Wessels 


\section{Promotores:}

Prof. dr. F.C.S. Ramaekers

Prof. dr. J. Troost

\section{Co-promotores:}

Dr. A.H.N. Hopman

Dr. A. Twijnstra

Beoordelingscommissie:

Prof. dr. J.P.M. Geraedts (voorzitter)

Prof. dr. E.A.M. Beuls

Prof. dr. P. Lambin

Prof. dr. P. Sillevis Smitt (Erasmus Medisch Centrum, Rotterdam)

Prof. dr. A. von Deimling (Humboldt Universiteit, Berlijn)

This thesis was prepared at the Department of Neurology, University Hospital Maastricht, and at the Department of Molecular Cell Biology, Maastricht University, The Netherlands.

The studies and the publication of this thesis were financially supported by the Dutch Cancer Society (Nederlandse Kankerbestrijding- Koningin Wilhelmina Fonds), Amsterdam, The Netherlands

Copyright: P.H. Wessels

Cover design: Trompert Medical Art, Maastricht

Produktie : Datawyse, Universitaire Pers Maastricht 


\section{Contents}

$\begin{array}{ll}\text { Abbreviations } & 6\end{array}$

$\begin{array}{ll}\text { General introduction } & 7\end{array}$

2 The dilemma of supratentorial astrocytoma grade II:

biological parameters and clinical course. astrocytoma by in situ hybridisation. correlates with shorter survival in astrocytoma grade II. young patients with astrocytoma grade II. changes in astrocytoma grade II and IV. 


\section{Abbreviations}

A II

A III

A IV

$\mathrm{CGH}$

CT-scanning

DMBT-gene

EGFR-gene

EORTC

FISH

ISH

Ki-67 LI

LOH

MRI

PTEN-gene

p-arm

q-arm
Astrocytoma grade II (low- grade diffuse astrocytoma)

Astrocytoma grade III (anaplastic astrocytoma)

Astrocytoma grade IV (glioblastoma multiforme)

Comparitive genomic hybridization

Computed tomography- scanning

Deleted in malignant brain tumor-gene

Epidermal growth factor receptor-gene

European organization for research and treatment of cancer

Fluorescence in situ hybridization

In situ hybridization

Ki-67 Labeling index

Loss of heterozygosity

Magnetic resonance imaging

Phosphatase and tensin homology-gene

Short arm of chromosome

Long arm of chromosome 
1

Introduction 
Gliomas are the most frequent primary intracranial neoplasms with an estimated incidence of 5.7 per 100.000 per year. ' On basis of the predominant cell type gliomas are classified as astrocytomas, oligodendrogliomas, ependymomas and mixed types (e.g. oligo-astrocytomas). ${ }^{2}$ Astrocytomas constitute about $80 \%-90 \%$ of gliomas. ${ }^{3}$ Based on histological characteristics astroytomas are subdivided into four grades with increasing malignancy. ${ }^{2,4}$

Astrocytomas grade II (A II) or low-grade diffuse astrocytomas and more specifically the supratentorial subtype occurring in adult patients, are the main subject of this thesis.

The main biological features of supratentorial adult A II comprise a diffuse infittration pattern into the adjacent normal brain and an inherent tendency to transform into high-grade astrocytomas, i.e. astrocytoma grade III (AIII), and astrocytoma grade IV (A IV). This malignant transformation of astrocytomas is accompanied by an accumulation of genetic aberrations.

Controversy exists upon optimal treatment of patients with A II, which may vary between gross tumor resection followed by immediate radiotherapy on the one hand, and a 'wait and see' policy on the other. This controversy is in particular caused by the unpredictable clinical course of A II.

The presence of cytogenetic aberrations in oligodendrogliomas and oligo-astrocytomas was shown to predict the sensitivity to chemotherapy of these tumors. ${ }^{5}$ In astrocytomas most cytogenetic studies have focused on A III and A IV. In A II fewer cytogenetic studies have been performed and their clinical relevance is until now not clear.

The main focus of this thesis was to evaluate the clinical application of molecular cytogenetic approaches in A II. For this purpose we used the in situ hybridization (ISH)assay, that allows detection of chromosomal loss or gain in single cells, as well as immunohistochemical assays, both in routinely processed brain tumors. ${ }^{\circ}$ 


\section{Aim of the studies}

In CHAPTER 1 an introduction of A II is given and factors that interfere with optimal treatment of A II are discussed, followed by a review of cytogenetic alterations that are associated with development of A II and of malignant progression to A III/ A IV. Possible applications of cytogenetic techniques in clinical practice of A II are suggested.

In CHAPTER 2 we assess whether the detection of chromosomal aberrations enhances the diagnostic sensitivity of sterotactic biopsy specimens. Tissues with an inconclusive histological diagnosis are analyzed by ISH, and these cytogenetic findings are compared with the findings in reactive gliosis and in A II.

In CHAPTER 3 the prognostic value of numerical aberrations for chromosome 7, frequently implicated in astrocytoma carcinogenesis, is investigated in a group of fortyseven A II patients.

The prognostic value of the cytogenetic parameters in this group of A II is compared with the prognostic value of clinical and biological parameters in CHAPTER 4.

In CHAPTER 5 we evaluate A II and A IV for aberrations of the centromere region of chromosome 10 and of the 10q25.3 region, where a tumor suppressor gene is located that may play a role in initiation of A II and/or malignant transformation to A III/ A IV. 


\section{References}

1. van der Sanden GAC, Schouten LJ, van Dijck JAAM, van Andel JP, Coebergh JWW. Incidence of primary central nervous system cancers in South and East Netherlands in 1989-1994. Neuroepidemiology 1998; 17: 247-257.

2. Kleihues P, Cavenee WK. Pathology and genetics of tumors of the nervous system. Lyon: International agency for research on cancer, 2000.

3. Kyritsis AP, Saya H. Epidemiology, cytogenetics, and molecular biology of brain tumors. Curr Opin Oncol 1993; 5:474-480.

4. Daumas-Duport C, Scheithauer B, OFallon J, Kelly P. Grading of astrocytomas. A simple and reproducible method. Cancer 1988; 62:2152-2165.

5. Cairncross JG, Ueki K, Zlatescu MC, et al. Specific genetic predictors of chemotherapeutic response and survival in patients with anaplastic oligodendrogliomas. J Natl Cancer Inst 1998; 90:1473-1479.

6. Arnoldus EP, Noordermeer IA, Peters AC, et al. Interphase cytogenetics of brain tumors. Genes Chromosomes Cancer 1991; 3:101-107. 



\section{2}

\section{The dilemma of astrocytoma grade II: biological parameters and clinical course}

Wessels PH, Weber WEJ, Raven G, Ramaekers FCS, Hopman AHN, Twijnstra A. The Lancet Neurology 2003: 2; 395-403. 



\begin{abstract}
Because of its unpredictable clinical course, treatment strategies for astrocytoma grade II (A II) may vary between 'wait and see' on the one hand, and gross tumour resection followed by immediate radiotherapy on the other. A survey of the clinical studies on astrocytoma grade II shows a 5-year survival ranging between $27.85 \%$ and a lack of consistent prognostic parameters, except for patient age and the presence of neurological deficit. At present no unequivocal guide exists for the choice of therapy for patients with an A II, also because of the shortcomings of histological classification systems. Routine microscopy tends to underestimate malignancy grading of astrocytomas and in most cases cannot distinguish between indolent and progressive subtypes. Recent studies suggest that with proliferation and genetic markers subgroups of A II with a rapid progressive clinical course can be identified. Therefore these markers should be included in ongoing and future clinical trials of patients with A II.
\end{abstract}




\section{Incidence of astrocytoma grade II and causal factors}

Astrocytoma grade II (A II), the most common variant of low-grade glioma, has an estimated incidence between 0.5-1.0 per 100.000 persons/ year.' A II have a peak incidence in early adulthood with the mean age of patients at time of diagnosis between 35 and 40 years. Only a small percentage of A II occur in patients before 18 or after 65 years of age. For unknown reasons there is a slight predominance in men (ratio 1.2). ${ }^{7}$ Most A II occur sporadically and rarely as a manifestation of a familial tumour syndrome. An example of the latter is the Li-Fraumeni syndrome, caused by an inherited mutation of the p53 tumour suppressor gene, in which astrocytomas may coexist with other solid tumours. "The only well-documented environmental risk factor for astrocytoma of all grades is skull irradiation in young patients with haematological malignancies. 'Although working in certain chemical industries e.g. synthetic rubber processing, petrochemical refineries and pesticide and fertilization manufacturing, was shown to be associated with an increased risk for brain tumours, causative agents have not been identified. ${ }^{10}$ Also there is little evidence that the use of cellular telephones enhances the risk for astrocytoma. "Furthermore the low variation of incidence rates for central nervous system tumours across Europe argues against specific environmental factors causing these malignancies. ${ }^{1,12}$ Epidemiological studies focussing on specific causal factors specific for A II have so far not been presented in the literature.

\section{Presenting symptoms and imaging of astrocytoma grade II}

Epileptic seizure is the most common presenting symptom of A II and occurs in approximately $80 \%$ of the patients. ${ }^{13 \cdot 15}$ This is probably due to the fact that A II show often a superficial localisation and low growth rate. ${ }^{16}$ Less common are focal neurological deficit (30\%) and mental changes (10-30\%). Uncommon are presenting symptoms due to raised intra-cranial pressure such as headache, vomiting and papilledema (10\%). ${ }^{13-15}$

In the pre-computed-tomography (CT)- era focal neurological deficit and raised intracranial pressure were reported in a higher percentage of patients with A II. ${ }^{17}$ The decline of these percentages in recent series is due to the use of modern neuro-imaging techniques and stereotactic-guided biopsies, allowing diagnosis of A II at an eartier stage. ${ }^{18}$ 


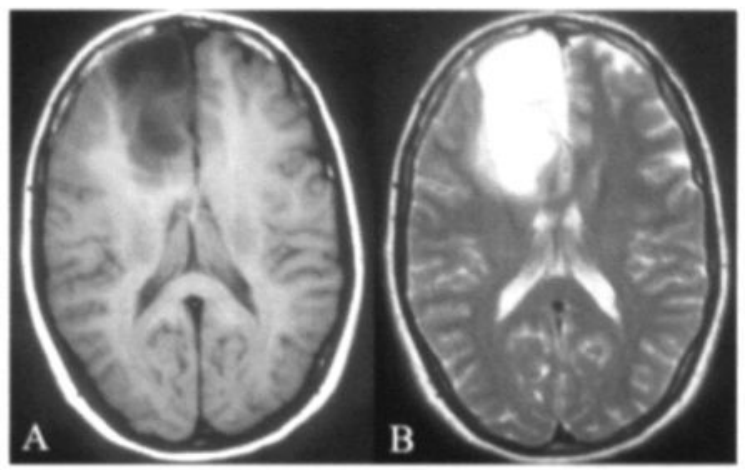

FIGURE 1. MRI of a astrocytoma grade II in the right frontal lobe. The lesion is hypo-intense in the $\mathrm{T} 1$-weighed image (A) and hyper-intense in the T2.weighed MRI image (B).

A II may arise anywhere in the hemispheres, but shows a preference for the frontal and temporal lobes. ${ }^{17.19}$ On CT-scans A II are typically hypodense, poorly demarcated and non-enhancing lesions. CT-scans tend to underestimate the size of A II. Magnetic resonance (MR) scanning is more sensitive than CT in detecting A $11 .{ }^{20}$ Upon MR-scanning A II are hypo-intense on T1-, and hyper-intense on T2-weighted scans (Figure 1). T2. weighed images provide a more accurate estimation of tumour size and infiltration by neoplastic astrocytes. ${ }^{21}$

Calcifications and cysts are sometimes present. ${ }^{22}$ Although fairly typical, these neuroimaging techniques are by no means diagnostic for A II. For example, contrastenhancement is occasionally observed in these malignancies. ${ }^{22}$ On the other hand, lesions with a typical A II appearance may well turn out to be high-grade gliomas, since one third of these more progressed malignancies show no contrast-enhancement. ${ }^{23-25}$ In the near future Positron emission tomography (PET) and proton magnetic resonance spectroscopy (MRS) may provide additional diagnostic precision in A II. PET with ${ }^{18} \mathrm{~F}$. fluorodeoxyglucose (FDG) may predict malignant transformation of low-grade glioma ${ }^{26}$ and PET with the amino acid tracer "C-methionine has a possible correlation with survival of low-grade glioma patients. ${ }^{27}$ PET appears to have potential in detection of glioma recurrence; stable or decreasing uptake of " $\mathrm{C}$ methionine after radiotherapy during follow-up is a favourable sign. ${ }^{28}$ MRS, measuring levels of lactate and choline in brain tumours enables discrimination between radionecrosis and tumour recurrence. ${ }^{29}$ 


\begin{tabular}{|c|c|c|c|c|c|c|c|c|c|c|c|c|c|c|c|}
\hline \multirow{7}{*}{ 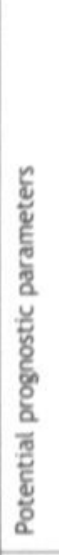 } & Radiation therapy & a & $\Sigma$ & & & $\Sigma$ & $a$ & & & $\tilde{z}$ & $\Sigma$ & 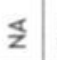 & za & $\tilde{z}$ & \\
\hline & Extent of resection & $\Sigma$ & $\Sigma$ & $a$ & & $a$ & $\tilde{z}$ & za & $\Sigma$ & $a$ & zz & a & $a$ & a & a \\
\hline & Contrast enhancement & & & & $\mathbf{z}$ & $\tilde{z}$ & 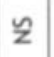 & & 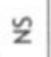 & & $\Sigma$ & & & $\Sigma$ & \\
\hline & Tumour volume & & & & & & $z$ & & & & $\Sigma$ & & & $\tilde{z}$ & \\
\hline & Performance score & & & a & $a$ & $a$ & & $a$ & a & & az & a & $a$ & & \\
\hline & Neurological deficit & & & z & $\frac{n}{2}$ & & & $\Sigma$ & & & $\Sigma$ & $\frac{\pi}{z}$ & & $z$ & \\
\hline & Patient age & $\mathbf{z}$ & $\mathbf{z}$ & $\mathbf{z}$ & $z$ & $\mathbf{z}$ & $\mathbf{z}$ & $z$ & $\Sigma$ & $\Sigma$ & $\Sigma$ & $z$ & $\Sigma$ & $\tilde{z}$ & $\mathbf{z}$ \\
\hline \multirow{3}{*}{ 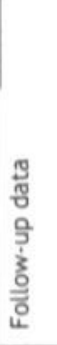 } & $\begin{array}{l}\text { Anaplastic change } \\
\text { (number reoperated) }\end{array}$ & & & & 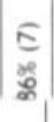 & 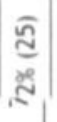 & & & 高 & & 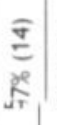 & $\frac{\sigma}{\partial}$ & & 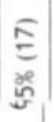 & \\
\hline & 10-year survival (\%) & $\approx$ & $\stackrel{2}{2}$ & ๆ & & 우 & $\bar{\nabla}$ & बे & 9 & & से & ส & 이 & R & $\tilde{m}$ \\
\hline & 5-year survival (\%) & $\overline{\text { n }}$ & 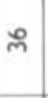 & นn & उ & 8 & 8 & กี & 요 & & ถ้ & $\stackrel{m}{\infty}:$ & $\overline{\text { in }}$ & $\infty$ & $\hat{0}$ \\
\hline \multicolumn{2}{|c|}{ Median patient age } & 이 & లి & & 心 & & 品 & & & $\hat{m}$ & mे & & $\hat{m}$ & 이 & $\tilde{m}$ \\
\hline \multicolumn{2}{|c|}{ Number of A II analyzed } & $\stackrel{\infty}{\wedge}$ & 8 & R & กิ & $\stackrel{શ}{શ}$ & $\stackrel{\Xi}{=}$ & $\infty$ & ก & กี & $g$ & 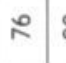 & \& & ณ & $\hat{\jmath}$ \\
\hline \multicolumn{2}{|c|}{ Reference } & 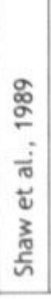 & 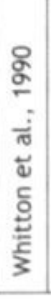 & 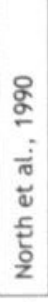 & 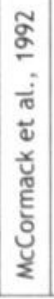 & 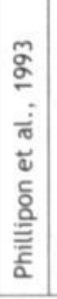 & 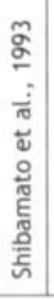 & 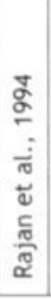 & 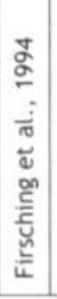 & 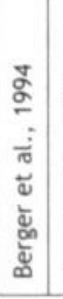 & 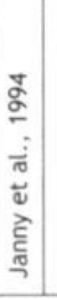 & 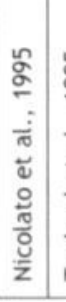 & 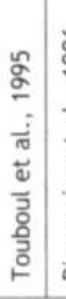 & 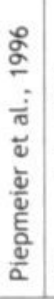 & 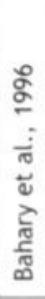 \\
\hline \multicolumn{2}{|c|}{ Study design } & \multicolumn{14}{|c|}{ Retrospective } \\
\hline
\end{tabular}




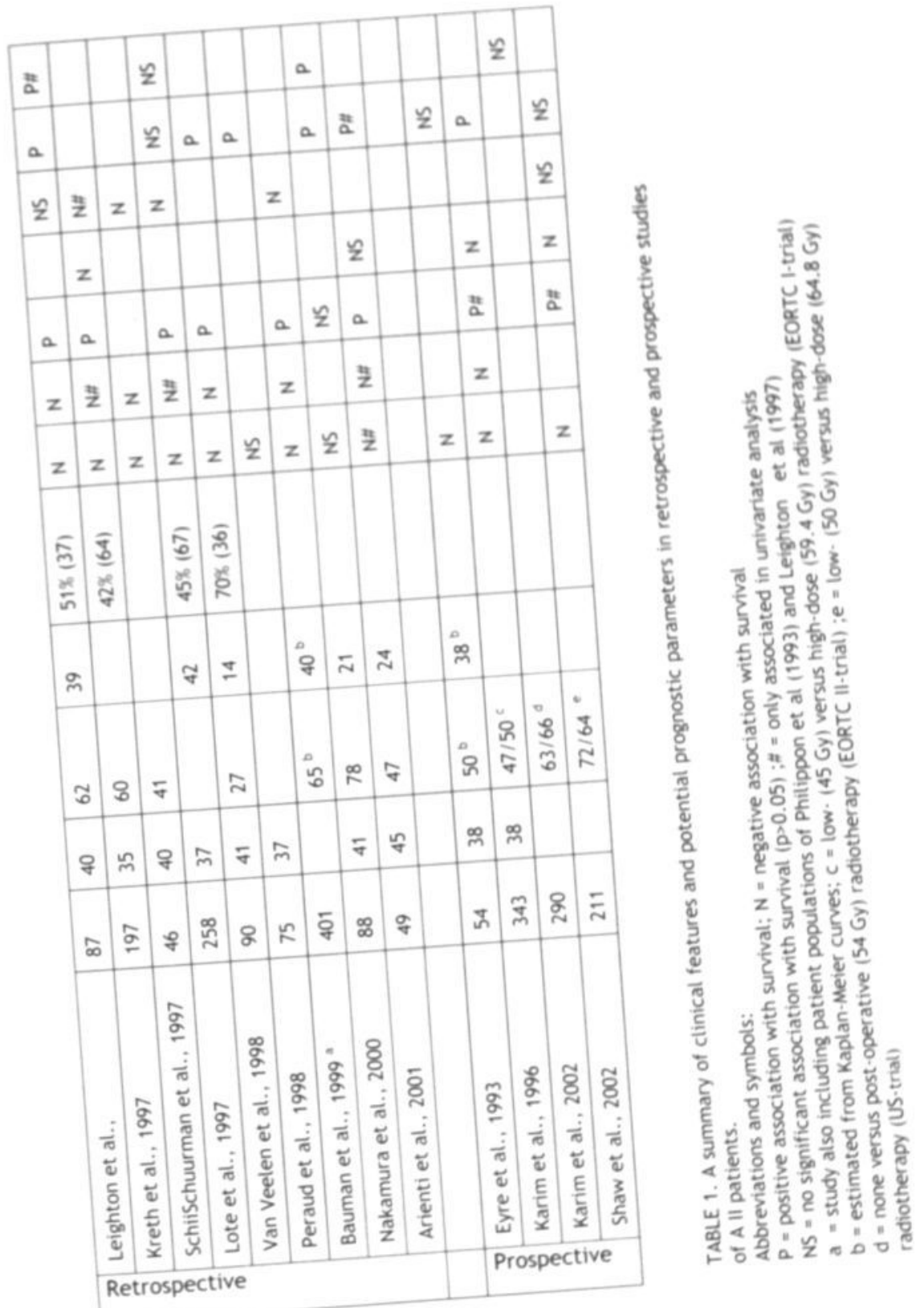




\section{Clinical course and prognostic parameters}

Although several clinical studies have tried to identify possible prognostic parameters for A II (see Table 1), its clinical behaviour is still largely unpredictable for several reasons. First, the proliferative and progressive behaviour of A II is highly variable. ${ }^{30}$ Second, studies on A II are difficult to interpret, as they are mostly retrospective in nature and include other subgroups of low-grade gliomas. Furthermore, the use of different treatment strategies may be an important confounder in most studies.

Table 1 summarises recent studies in which CT and MR have been applied to predict the clinical course, and which have attempted to describe prognostic parameters of A II. ${ }^{7.13}$. 15.19.31.52 The 5-and 10-year survival rate of patients in A II studies varies largely, i.e. between $27 \%-85 \%$ and $14-70 \%$, respectively. Only four prospective randomised trials have been conducted in low-grade glioma patients, two of which have only recently been published. ${ }^{49.52}$ All other studies are retrospective, and often include not only A II, but also other variants of low-grade gliomas, such as pilocytic astrocytomas, oligodendrogliomas and oligo-astrocytomas, which have a better prognosis than A II. ${ }^{15,17,31,44,50}$ Apart from study inclusion heterogeneity, another source of bias lies in the variance of treatment strategies. Few studies describe patient selection for different treatment strategies, e.g. biopsy followed by a "wait and see" strategy, or gross tumour resection with immediate post-operative radiotherapy. Because of this lack of information the impact of timing and type of interventions on the clinical course of A II is difficult to assess.

Patient age is the most consistent prognostic parameter in these studies. Patient age under 35 years ${ }^{7,48}$ or under 40 years in other series ${ }^{46,53}$ is associated with increased survival. In most studies epilepsy as presenting symptom and high performance status are also significantly associated with a more favourable clinical course.

Other factors with a less clear association are tumour volume, extent of tumour resection, contrast enhancement, as well as timing and dose of radiation therapy (Table 1).

An analysis of prognostic parameters from the two intervention studies conducted by the European Organization for Research and Treatment of Cancer (EORTC), was recently reported (see also: treatment strategies). In this report: age over 40 years, presence of neurologic deficits, astrocytoma histology, tumour crossing the midline and tumor diameter larger than $6 \mathrm{~cm}$ were associated with shorter survival of low-grade glioma patients. ${ }^{53}$ Diffuse infiltration of tumour cells into normal brain makes total resection of A II often impossible, ultimately leading to disease progression, either 
caused by expansive tumour growth or by malignant transformation into A III or A IV. The percentage of A II with progression to high-grade astrocytoma (A III/A IV) is reported to vary between $35 \%$ and $89 \%$. However, documentation of histological diagnoses at second biopsy, at resection or at autopsy is limited (Table 1). ${ }^{13}$. 15,17,33,38.39.44.54 A review from the pre-CT- era demonstrated that two thirds of low-grade astrocytomas exhibited a higher malignancy grade at time of re-operation."

On basis of their clinical course mainly two different subgroups of A II can be defined, i.e. A II that remain indolent for years causing chronic epilepsy (indolent A II), or A II that cause progressive neurological deficit (progressive A II). Indolent A II are more often located in the grey matter, whereas progressive A II are more often located in the white matter. ${ }^{43.54}$ This is illustrated by the favourable outcome in patients with cortical located A II, who underwent (incomplete) resection of these tumours because of intractable seizures. ${ }^{56}$ This suggests that the cellular origin of A II may be an important factor determining its clinical course. Piepmeier and colleagues ${ }^{54}$ found support for this hypothesis showing a difference in clinical behaviour, i.e. localisation and duration of symptoms, amongst tumours arising from different astrocyte lineages.

\section{Treatment strategies}

Patient age is a decisive parameter in current treatment strategies of A II. In fact, A II occurring in older patients often behave more malignantly than high-grade astrocytomas in younger patients. When grading patient age most studies use 40 years and some others 35 years as cut-off points. There seems to be consensus that patients over 35.40 years of age should undergo an aggressive treatment, i.e. maximal tumour resection followed by radiation therapy. ${ }^{7.57}$

The same applies for the consensus on surgery for younger patients with increased intracranial pressure, neurological deficits related to mass effect and uncontrollable seizures. There is less consensus on the role of surgery in A II without significant masseffect in young patients with medically controllable seizures (For a review see Keles et al, reference 53). However, for A II in non-eloquent areas, tumour resection is often preferred because of association with better prognosis in most retrospective studies of A II. These positive effects of tumour resection may, however be explained by selection bias, ${ }^{17,37,38}$ since tumour resection may have a (temporary) beneficial effect by reducing the space-occupying mass of A II. An influence of tumour resection on the pace and rate of malignant transformation has so far not been demonstrated. 
Timing and dose of radiation therapy is also under debate. The first randomised EORTC(European Organisation for Research and Treatment of Cancer) trial found no differences in outcome between low-grade glioma patients who underwent low-dose (45 Gy) versus high-dose (59.4 Gy) post-operative radiation therapy ('the believers trial')..$^{50}$ This was confirmed by the recently published trial of the American Radiation Therapy Oncology groups ('the US trial'), which also found no difference in survival between low ( $50.4 \mathrm{~Gy}$ ) and high-dose (64.8 Gy) localised radiation therapy. ${ }^{52}$ In the second EORTC-trial, immediate post-operative radiation therapy was compared to postponed radiation therapy at the time of disease progression ('the non-believers trial')..$^{51}$ In this trial immediate post-operative radiation of 54 Gy resulted in longer progression-free survival, but had no effect on overall survival. ${ }^{51}$

The results of these trials are difficult to extrapolate to young A II patients, because separate analysis of different age- or histological subgroups has not been reported so far.

In fact, interpretation of these trials is hampered by apparent histological heterogeneity of the tumours studied. In the US trial the majority (68\%) of the lowgrade glioma comprised oligodendrogliomas or oligo-astrocytomas. ${ }^{52}$ In the second EORTC trial $22 \%$ of the tumours were reclassified as A III/A IV after histo-pathological review. ${ }^{51}$

In view of its dubious positive effects one also has to take into account the possible side-effects of radiation therapy, especially the risk for radiation-induced encephalopathy. A recent Dutch multi-centre study ${ }^{58}$ showed that encephalopathy occurs when repeated high-fraction doses (> $2 \mathrm{~Gy}$ ) are used. The authors concluded that otherwise cognitive dysfunction in low-grade glioma patients is mainly due to the malignancy itself and to possible side-effects of anti-epileptic drugs. ${ }^{58}$

Routine chemotherapy for A II patients is not indicated. ${ }^{49}$ The only prospective trial reported to date revealed no difference between low-grade glioma patients treated with radiotherapy plus CCNU versus radiotherapy alone. ${ }^{49} \mathrm{~A}$ trial by the Radiation Oncology Group (RTOG 98-02) in which patients with unfavourable low-grade glioma, defined as patient age $>40$ years and/or incomplete resection, were randomised to radiation therapy plus $\mathrm{PCV}$ chemotherapy versus radiation therapy alone, was recently closed. Analysis of the data is not yet concluded. The efficacy of the oral chemotherapeutic drug imatinib mesylate in recurrent low-grade gliomas is currently tested in a phase II trial (EORTC coordinator Dr MJ van den Bent, Erasmus Medical Centre, Rotterdam; E-mail: bent@neuh.azr.nt). From a recent phase II trial is concluded that the oral chemotherapeutic drug temozolomide may be active in progressive low-grade gliomas ${ }^{59}$, which will be investigated in future phase III trials. ${ }^{60}$ 
As there is no clear-cut evidence to guide treatment choices in young patients with A II, one can also question the necessity of histopathological diagnosis in these cases. ${ }^{5,57,61}$ Histological confirmation does not always alter treatment strategy and a stereotactic biopsy is not without risks. A retrospective study showed that patients with transient neurological symptoms and radiological suspicion of a low-grade glioma had a median survival that was unaltered when postponing biopsy and other interventions until disease progression. ${ }^{61}$ One can argue that this 'wait and see' policy, with its uncertainty about the diagnosis, negatively influences the quality of life of patients with suspected low-grade glioma. This was, however, not confirmed in a recent study, where no difference in quality of life was found between patients with suspected and with proven low-grade gliomas. ${ }^{62}$

\section{Histological grading systems}

At present astrocytomas are either classified according to the St. Anne/Mayo grading system ${ }^{4}$ or according to the World Health Organisation (WHO) protocol. ${ }^{2}$ In both systems tumors are graded in the area with most anaplastic features using the following histopathological features: nuclear atypia, mitotic activity, endothelial proliferation and necrosis (Table 2).

The St. Anne/Mayo system divides astrocytomas into four grades. However in practice this is a three-grade system because grade 1 astrocytomas are extremely rare. The most prominent feature of St. Anne/Mayo grade 2 is nuclear atypia. The absence or presence of mitotic figures differentiates between grades 2 and 3. The St. Anne/Mayo astrocytoma grade 2 is comparable to 'astrocytoma grade II' or 'diffuse astrocytoma' in the WHO definition, i.e. a tumour with a moderately increased cellularity of astrocytes and occasional nuclear atypia. Mitotic activity is generally absent. ${ }^{2}$ A difference between the two classification systems concerning A II lies therefore in the fact that WHO allows for the detection of a single mitosis. ${ }^{2}$ On basis of the type of astrocyte that is predominantly present three variants of A II can be distinguished, i.e. the fibrillary, the gemistoytic and the protoplasmic A II. Fibrillary A II is by far the most common variant, exhibiting an extensive network of neuroglial fibrils extending between the 


\begin{tabular}{|l|l|}
\hline \multicolumn{2}{|l|}{ St. Anne-Mayo (1988) } \\
\hline Grade & Definition \\
\hline 1 & No histological features present \\
\hline 2 & One histological feature present, usually nuclear atypia \\
\hline 3 & Two features present, typically nuclear atypia and mitoses \\
\hline 4 & $\begin{array}{l}\text { Three of four features present, i.e. nuclear atypia, mitoses } \\
\text { and microvascular proliferation and/ or necrosis }\end{array}$ \\
\hline
\end{tabular}

\begin{tabular}{|l|l|}
\hline \multicolumn{2}{|l|}{ World Heath Organisation- WHO (2000) } \\
\hline Grade & Definition \\
\hline I & $\begin{array}{l}\text { Pilocytic astrocytoma: } \\
\text { Circumscribed tumour especially occurring in children }\end{array}$ \\
\hline II & $\begin{array}{l}\text { Diffuse astrocytoma : } \\
\text { Moderate hypercellularity and occasional nuclear atypia. } \\
\text { Mitosis absent or in single cell }\end{array}$ \\
\hline III & $\begin{array}{l}\text { Anaplastic astrocytoma: } \\
\text { Hypercellularity and distinct nuclear atypia. } \\
\text { Marked mitotic activity }\end{array}$ \\
\hline IV & $\begin{array}{l}\text { Glioblastoma multiforme: } \\
\text { Marked nuclear atypia and brisk mitotic activity. } \\
\text { Prominent microvascular proliferation and/ or tumor necrosis }\end{array}$ \\
\hline
\end{tabular}

TABLE 2. Histopathological classification systems of astrocytoma.

astrocytes (Figure 2). Gemistocytic A II is characterised by large astrocytes with eccentric nuclei. Although these tumours are all classified as WHO grade II, the presence of a high percentage (>20\%) of gemistocytes is associated with shorter survival. ${ }^{63}$ Some authors, therefore consider gemistocytic astrocytoma as a variant of anaplastic astrocytoma (WHO grade III) ${ }^{64}$. The very rare protoplasmic A II, characterised by mucoid degeneration and microcyst formation, often has an indolent clinical course. ${ }^{65}$

In both grading systems increasing malignancy grade is associated with a less favourable prognosis. ${ }^{4.66 .67}$ This is clearly shown in Figure 3, depicting the survival curves from the study of Daumas-Duport et $\mathrm{at}^{4}$ for astrocytomas graded according to the St. AnneMayo system. From these data it may be appreciated that for the individual patients these histological classification systems are less useful, as survival within one grade may vary widely. Conversely, survival between different grades may show significant overlap, as is the case between A II and A III. ${ }^{68}$ Histological heterogeneity within the tumour is another major source of confusion when the diagnosis is based on fragments 


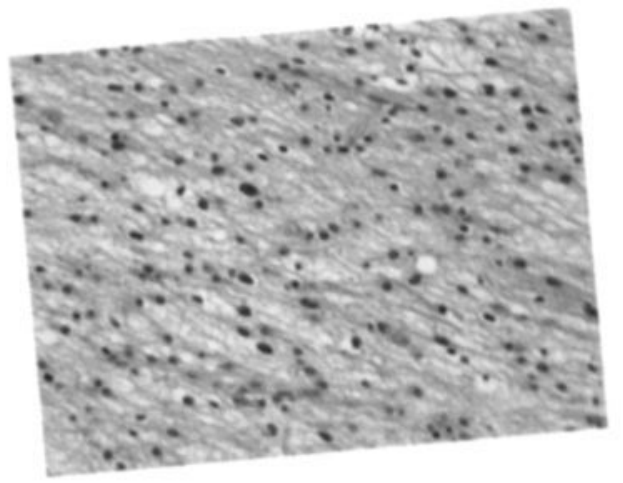

FIGURE 2. Fibrillary A II with an increased cellularity and size of the astrocytes.

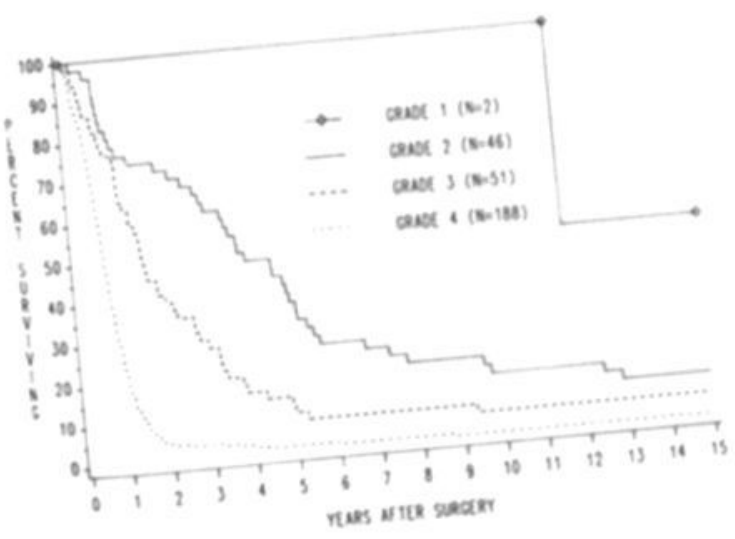
FIGURE 3. Survival curves for patients with astrocytomas classified according to the St. Anne/
Mayo grading system (Cancer, Vol. 62, No. 10, 1988, page 2157. Reprinted by permission of Wiley-Liss.) histological grade in $10-25 \%$ of astrocytomas, as compared to resection specimens of 
the same tumour. ${ }^{70-72}$ This risk of underestimation is reduced by taking a larger number (>6) of stereotactic biopsies per tumour. ${ }^{n}$

The differentiation between 'pure'astrocytoma and mixed oligo-astrocytomas is of clinical relevance, because the presence of an oligodendrogtioma component increases the chance of chemo-sensitivity. ${ }^{73}$ However this distinction may be difficult because tumour cells may often combine astrocytic and oligodendroglial features, while also the histological diagnosis is influenced by heterogeneity within the specimen. ${ }^{74}$

Finally, a problem in clinical practice of stereotactic biopsy specimens is the differentiation between A II and reactive gliosis, a proliferation of glial cells in response to neural tissue damage. Both tissue types may only show a mild increase in astrocyte cellularity and some nuclear atypia using routine microscopy and histological diagnosis often remains inconclusive in such cases. ${ }^{75}$

\section{Biological aspects of astrocytoma grade II}

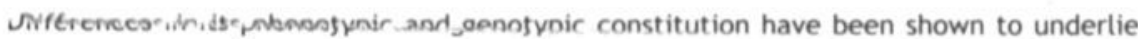
the variable clinical course of individual cases of All. The development of astrocytoma is associated with genetic instability and an imbalance between proliferation and programmed cell death (apoptosis) of astrocytes. Recent studies have suggested that markers for proliferation activity ${ }^{76,77}$ and certain cytogenetic changes ${ }^{78,79}$ may predict the malignant transformation from A II to A III/A IV.

\section{Proliferation markers in astrocytoma grade II}

An established histological method to estimate proliferative activity in tumours is to count the percentage of cells with mitotic figures. However, since in A II mitoses are absent by definition, other procedures for the determination of its proliferative capacity have been sought, amongst which the bromodeoxyuridine $(\mathrm{BrdU})^{80,81}$ incorporation assay, or immunostaining of the Proliferating Cell Nuclear Antigen (PCNA) ${ }^{82}$ and the Ki-67-antigen. ${ }^{77}$ Although the two former protocols showed prognostic value the latter has shown to provide the most reliable estimate of the proliferative ratio in brain tumours and to be easily applicable in routine pathology. ${ }^{83,84}$ The Ki-67 antigen is present in all active phases of the cell cycle, but absent in $G_{0}$ phase. Specific 
antibodies allow its detection in routinely processed material of gliomas. ${ }^{32}$ The percentage of Ki-67 positive cells, expressed as the Ki-67-labeling index (LI) has a positive correlation with histological grade in astrocytomas. In a series of grade II astrocytomas a $\mathrm{Ki}-67 \mathrm{LI}$ of more than $2 \%$ was predictive of shorter survival, independent of the patient's age. ${ }^{76}$

\section{Molecular cytogenetics of astrocytomas}

Different molecular techniques, including karyotyping, ${ }^{85}$ mutation analysis, ${ }^{\circ 6}$ allelotyping, ${ }^{87}$ in situ hybridization (ISH), ${ }^{6}$ comparative genomic hybridisation (CGH) ${ }^{38}$ and expression profiling ${ }^{89}$ have been used to study astrocytomas.

In particular the in situ hybridization (ISH) and the comparative genomic hybridization (CGH) technique are well suited for the analyses of numerical and structural chromosomal aberrations. The ISH technique uses chromosome specific DNA probes that allow the detection of chromosomal imbalances, e.g. losses, gains and amplifications, in individual cells of paraffin-embedded brain tumour samples. ${ }^{6.90,91}$ The ISH assay is particularly well suited for the study of A II, which is often surrounded by reactive, non-neoplastic, cells, and from which frequently only small stereotactic biopsy samples with a limited number of cells are available. An typical example of a FISH-assay for chromosome 1 and 7 in an A II is shown in Figure 4.

When relatively large and more homogeneous samples are available the CGH assay allows detection of gains and losses of genetic material across the entire tumour genome. ${ }^{92}$ In CGH differently fluorescent labelled tumour DNA and normal reference DNA are hybridised simultaneously to normal metaphase chromosomes. Digital analysis of the fluorescence intensity ratios enables to detect chromosomal gains or losses of 2 Megabases (Mb) or more, as exemplified in Figure 5.

Table 3 summarizes frequent chromosomal alterations that have been found in the different grades of astrocytomas (Table compiled on basis of references ${ }^{2.93-95}$ ). From this table it is obvious that only few of the target genes that are either enhanced or lost through the chromosomal changes have been identified.

Typical chromosomal aberrations in A II include loss or mutation of the p53 tumour suppressor gene and trisomy for chromosome 7.

In A IV two distinct genetic subtypes exist, namely primary (or de novo) and secondary (or progressive) A IV.\% In primary A IV no prior evidence for a low-grade precursor lesion exists. Typical aberrations in these tumours include amplification of the epidermal growth factor receptor (EGFR)-gene, ${ }^{97}$ located on chromosome 7, and loss of chromosome $10,{ }^{98}$ where the PTEN/MUAC1 tumour suppressor gene is located. ${ }^{85}$ 


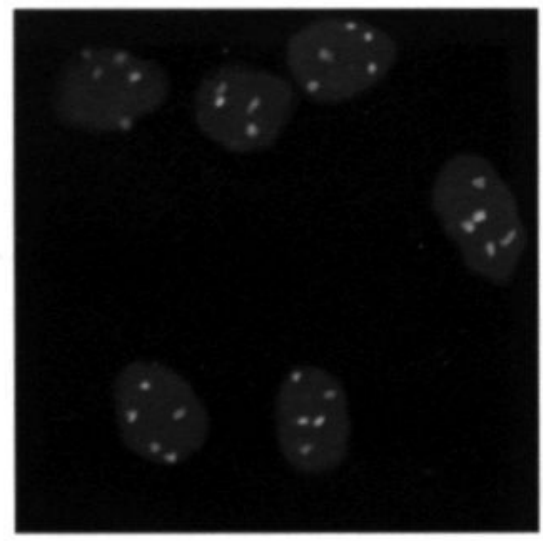

FIGURE 4. Double-target fluorescence in situ hybridization (FISH) demonstrating trisomy for chromosome 7 (green signals) and a normal copy number for chromosome 1 (red signals) in an astrocytoma grade II. The nuclei are counterstained with DAPI (blue).
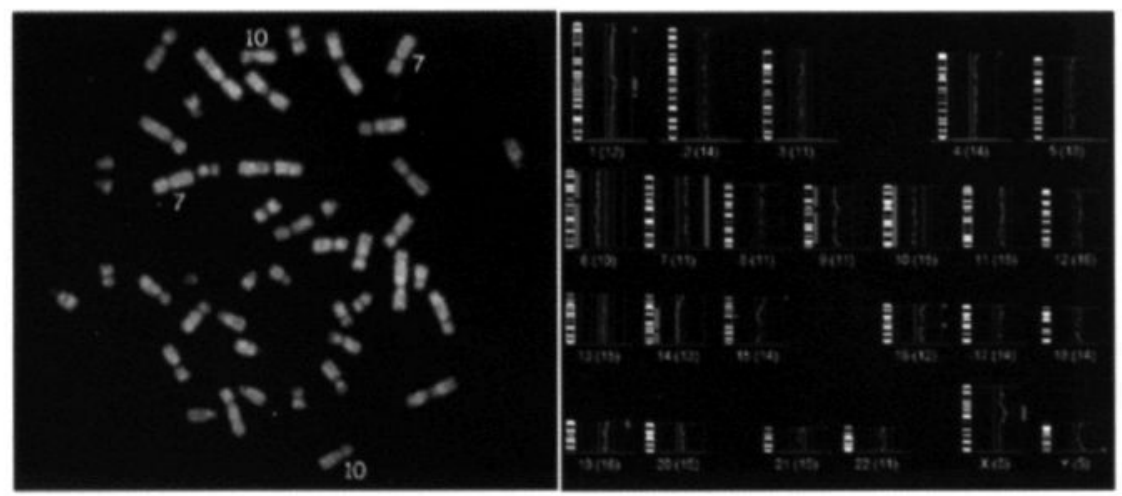

FIGURE 5 Comparative genomic hybridization (CGH) analysis of an astrocytoma grade IV in which gain for chromosome 7, and losses of chromosomes 10,6, 9 and 14q are clearly visible.

A) Fluorescent ratio image; tumour DNA (green) and normal reference DNA (red) are hybridized to a normal metaphase. B) Average ratio profile calculated from 10 metaphases. The red bar indicates chromosomal loss while the green bar indicates gain of chromosomal regions. (Image courtesy of Dr EJM Speel and Mrs SMH Claessen, Department of Molecular Cell Biology. University of Maastricht, The Netherlands) 


\begin{tabular}{|c|c|c|c|c|}
\hline $\begin{array}{l}\text { Tumor } \\
\text { subtype }\end{array}$ & $\begin{array}{l}\text { Chromosome } \\
\text { aberration }\end{array}$ & $\begin{array}{l}\text { Frequencyof } \\
\text { aberrations }\end{array}$ & Gene involved (locus) & $\begin{array}{l}\text { Altered protein } \\
\text { expression }\end{array}$ \\
\hline$A \|$ & $\begin{array}{l}-17 p \\
+7 \\
+8 q \\
-22 q \\
-10 p \\
-10 q\end{array}$ & $\begin{array}{l}60-70 \% \\
10-50 \% \\
0.40 \% \\
15-20 \% \\
0.20 \% \\
0.20 \%\end{array}$ & $\begin{array}{l}\text { P53 (17p13.1) } \\
\text { EGFR (7p12-14) } \\
\text { C-MYC (8q22) } \\
\text { NF2 (22q12) } \\
\text { Unknown (10p14) } \\
\text { DMBT }(10 \mathrm{q} 25) \\
\text { PDGFR }(4 \mathrm{q} 11-12)\end{array}$ & PDGFRo $\uparrow$ \\
\hline A III & $\begin{array}{l}-9 p \\
+12 q \\
-13 q \\
-19 q\end{array}$ & $\begin{array}{l}20-30 \% \\
10-20 \% \\
20-25 \% \\
40-50 \%\end{array}$ & $\begin{array}{l}\text { Ink4A }(9 p 21) \\
\text { CDK4 (12q13-14) } \\
\text { RB(13q14) } \\
\text { Unknown (19q13) }\end{array}$ & \\
\hline $\begin{array}{l}\text { Secondary } \\
\text { AIV }\end{array}$ & $\begin{array}{l}-17 p \\
-10 q \\
-19 q\end{array}$ & $\begin{array}{l}60-70 \% \\
70-80 \% \\
50-60 \%\end{array}$ & $\begin{array}{l}\text { P53 (17p13.1) } \\
\text { DMBT (10q25) } \\
\text { Unknown (19q13) } \\
\text { DCC (18q21) }\end{array}$ & $D C C \downarrow$ \\
\hline $\begin{array}{l}\text { Primary } \\
\text { A IV }\end{array}$ & $\begin{array}{l}-10 \\
+7 \\
-9 p \\
+12 q\end{array}$ & $\begin{array}{l}70-80 \% \\
50-80 \% \\
30-60 \% \\
10 \%\end{array}$ & $\begin{array}{l}\text { PTEN }(10 q 23.3) \\
\text { EGFR (7p12-13) } \\
\text { Ink4a/ARF }(9 p 21) \\
\text { MDM2 (12q14-15) }\end{array}$ & $\begin{array}{l}\text { EGFR } \uparrow \\
M D M 2 \uparrow\end{array}$ \\
\hline
\end{tabular}

TABLE 3. A summary of common genetic abnormalities reported for the different grades of astrocytoma.

Abbreviations: PDGFR= platelet derived growth factor receptor, EGFR= epidermal growth factor receptor, $\mathrm{NF}=$ neurofibromatosis, DMBT = deleted in malignant brain tumour. $\mathrm{CDK}$ - cycline dependant kinase,

$\mathrm{Rb}=$ retinoblastoma, $\mathrm{PTEN}=$ phosphatase tyrosine gene, $\mathrm{MDM}=$ murine double-minute, $\mathrm{DCC}=$ deleted in color carcinoma. 
An example of a primary A IV with gain of chromosome 7 and loss of chromosome 10 , detected by $\mathrm{CGH}$, is shown in figure 5 .

In both A II and secondary A IV, losses of chromosome arm 17p with mutation of the p53 tumour suppressor gene are often present. Other genetic alterations are less frequent in A II as compared to A IV. The cytogenetic alterations that are associated with two important aspects of A II i.e. initiation of A II and malignant progression of A II to A III or secondary A IV, are discussed below.

\section{Initiation of astrocytoma grade II}

In about two thirds of the cases of A II studied mutation or loss of the p53 tumoursuppressor-gene on chromosome $17 p 13.1$ is present. ${ }^{99}$ Several protein regions of P53 play different roles in cellular processes, one of the most important being the regulation of gene transcription. Absence of functional P53 protein leads to a deregulation of the cell cycle and absence of induction of the normal process of apoptosis, thereby also leading to genomic instability. Although loss or mutation of the p53-gene have been suggested as early lesions in the process of initiation of astrocytoma, additional genetic alterations are necessary for astrocytoma carcinogenesis. An important mechanism for growth stimulation of astrocytomas is the simultaneous overexpression of growth factors receptors and their receptors, leading to an autocrine stimulation of the RAS-signalling pathway. ${ }^{100} \mathrm{~A}$ frequently overexpressed growth factor in A II is the platelet derived growth factor receptor alpha (PDGFR-a) subunit. ${ }^{101}$ A close correlation has been found between overexpression of PDGFR- $\square$ and LOH of $17 p$, the locus of the p53 gene, which suggests that growth stimulation and p53 mutation may have synergistic effect in the initiation of All.

Recent ISH and CGH studies have shown that other chromosomal aberrations also often occur in A II, i.e. gains of chromosome 7 or $7 q, 8 q$ and general polyploidisaton. ${ }^{79,102-105}$ A typical example of gain of chromosome7 in an A II, as detected by fluorescence-ISH (FISH) is shown in Figure 4. As a target on chromosome 7p the Epidermal Growth Factor Receptor (EGFR) gene has been suggested, but amplifications of this gene are very rare in A II. ${ }^{106}$ Loss of regions on $22 \mathrm{q}$ has also been observed in A II. The neurofibromatosis 2

(NF2) gene located in this region has however been eliminated as a candidate tumour suppressor gene by mutation analysis. ${ }^{107}$ Furthermore deletions of regions of chromosome 10, i.e. 10p14-15 and 10q25-26, have been found in A II. ${ }^{108}$ 


\section{Malignant progression of A II to A III or secondary A IV}

An important role in malignant progression of A $\|$ has been suggested for cell cycle regulator genes involved in the Ink4A-CDK4-Rb pathway (see Table 3). Ink4A (or p16) and CDK4 code for proteins that regulate phosphorylation of the retinoblastoma (Rb) protein, which in turn regulates transition from the $G$, to the $S$ phase of the cell cycle. In approximately half of the A III tumours either one of these three genes is mutated (see Table 3), which is an explanation for uncontrolled cell proliferation. ${ }^{100,110}$ Another frequent alteration in both A III and secondary A IV is chromosomal loss of $19 \mathrm{q}$ where an unidentified tumour suppressor gene is located that might play a role in A II progression."'

Molecular allelotyping studies suggest that (secondary) A IV that have progressed from A II have a common deletion of the 10 q25-26 region. ${ }^{112}$ One of the candidate tumor suppressor genes in this region is the Deleted in Malignant Brain Tumor (DMBT1) gene, the product of which has been linked to processes of cell differentiation and migration of epithelial cells. ${ }^{13}$ Major hallmarks of primary A IV are loss of chromosome 10 with PTEN/MUAC1 mutation and amplification and/or overexpression of the EGFR gene. ${ }^{\text {" }}$ In primary A IV the P53 pathway is also disrupted, through loss of ARF, or less frequently through amplification of MDM2.

\section{Clinical application of molecular markers in A II}

With regard to the prognostic value of molecular cytogenetics in A II it can be stated that a higher number of genetic alterations, as detected by $\mathrm{CGH}$, is associated with a more rapid malignant progression. ${ }^{78}$ Using ISH it was shown that trisomy of chromosome 7 is associated with shorter survival of A II patients. ${ }^{79}$

A possible association of p53 mutations with survival has been suggested by some studies 114 , but contradicted by others. ${ }^{115}$ A recent study suggest that mutation of codon 175 ('a hot spot codon') of the p53 gene is associated with a shorter patient survival in A II. ${ }^{116}$

Molecular analyses are also of potential interest when a (stereotactic) sample error is suspected. At one side the detection of trisomy for chromosome 7 might help to discriminate between non-neoplastic reactive gliosis and A II in case of an inconclusive histological diagnosis. ${ }^{117}$ On the other hand the detection of monosomy for chromosome 10 , distinctly uncommon in A II, may help to discriminate between A II and A IV. ${ }^{103}$ 
Furthermore demonstration of loss of chromosomes $1 p$ and $19 q$ is already of value in predicting chemosensitivity of oligodendroglioma and mixed oligo-astrocytomas. Similar losses have also been observed in a minority of A II 105,107,118, suggesting that the detection of these alterations may also predict chemo-sensitivity of a subgroup of (histological) A II with oligodendroglial genotype. 5,119

The first CDNA expression array study, showing up- and down-regulation of different genes that have not been implicated in astrocytoma carcinogenesis before, confirms the complexity of genetic alterations in A $11 .^{89}$ From a cDNA-array study in high-grade glioma the potential use of this technique toward a molecular, instead of a histological classification of gliomas, is suggested. ${ }^{120}$

\section{Conclusions}

Managing patients with A II poses a therapeutic dilemma. Because of its unpredictable clinical course, treatment strategies may vary between gross tumour resection followed by immediate radiotherapy on the one hand, and a 'wait and see' approach on the other hand. At present the best prognostic parameter is patient age, while other clinical parameters correlating with prognosis are the presence of neurological deficit and a low performance score at time of presentation.

In particular for young patients (under 35 or $\mathbf{4 0}$ years of age) with A II that only cause seizures, the efficacy of surgical intervention and early radiotherapy has never been proven. Since histological confirmation through stereotactic biopsy does not alter the treatment strategy a 'wait and see' policy is often recommended for these patients.

For A II that occur in patients over 40 years of age and A II that have a mass effect or progressive neurological deficit, gross total tumour resection improves survival. The role of post-operative radiotherapy is still under debate, however if applied the fraction dose should not exceed $2 \mathrm{~Gy}$ and a total dose of $45 \mathrm{~Gy}$ is probably as effective as $59.4 \mathrm{~Gy}$. Routine treatment with chemotherapy is not indicated for A II patients, and at present serves only as a salvage therapy for recurrent A II.

Recent data suggests that biological and genetic parameters closely correlate with the highly variable clinical course of A II. Of these the Ki-67 proliferation marker should be included in routine pathology. Analysis of these tumours could include genetic alterations, in particular gain of chromosome 7 (monitored by ISH) and losses of $1 \mathrm{p} / 19 \mathrm{q}$ (monitored by $\mathrm{CGH}$ ), or attered gene expression as determined by CDNA expression arrays. These markers are promising candidates to serve as prognostic 
indicators in A II and the analysis of tumour biopsies should therefore be imperatively integrated into clinical trials to prospectively identify outcome predictors as tools for improvement of diagnosis and treatment in the future. 


\section{References}

1. van der Sanden GA, Schouten LJ, van Dijck JA, van Andel JP, Coebergh J. Incidence of primary central nervous system cancers in South and East Netherlands in 1989-1994. Neuroepidemiology 1998;17:247-57.

2. Kleihues P, Cavenee WK, eds. Pathology and genetics of tumors of the nervous system. 2nd edn Lyon: International agency for research on cancer, 2000.

3. Kyritsis AP, Saya H. Epidemiology, cytogenetics, and molecular biology of brain tumors. Curr Opin Oncol 1993;5:474-80.

4. Daumas-Duport C, Scheithauer B, OFallon J, Kelly P. Grading of astrocytomas. A simple and reproducible method. Cancer 1988;62:2152-65.

5. Cairncross JG, Ueki K, Zlatescu MC, et al. Specific genetic predictors of chemotherapeutic response and survival in patients with anaplastic oligodendrogliomas. J Natl Cancer Inst 1998; $90: 1473.9$.

6. Arnoldus EP, Noordermeer IA, Peters AC, et al. Interphase cytogenetics of brain tumors. Genes Chromosomes Cancer 1991;3:101-7.

7. Shaw EG, Daumas-Duport C, Scheithauer BW, et al. Radiation therapy in the management of low-grade supratentorial astrocytomas. J Neurosurg 1989;70:853-61.

8. Louis DN, von Deimling A. Hereditary tumor syndromes of the nervous system: overview and rare syndromes. Brain Pathol 1995;5:145-51.

9. Salvati M, Artico M, Caruso R, Rocchi G, Orlando ER, Nucci F. A report on radiationinduced gliomas. Cancer 1991;67:392-7.

10. Preston-Martin S. Epidemiology of primary CNS neoplasms. Neurol Clin 1996;14:273-90.

11. Inskip PD, Tarone RE, Hatch EE, et al. Cellular-telephone use and brain tumors. $N$ Engl $J$ Med 2001;344:79-86.

12. Fleury A, Menegoz F, Grosclaude P, et al. Descriptive epidemiology of cerebral gliomas in France. Cancer 1997;79:1195-202.

13. Lote K, Egeland T, Hager B, et al. Survival, prognostic factors, and therapeutic efficacy in low-grade glioma: a retrospective study in 379 patients. J Clin Oncol 1997;15:3129-40.

14. Kreth FW, Faist M, Rossner R, Volk B, Ostertag CB. Supratentorial World Health Organization Grade 2 astrocytomas and oligoastrocytomas. A new pattern of prognostic factors. Cancer 1997; 79:370-9.

15. Leighton C, Fisher B, Bauman G, et at. Supratentorial low-grade glioma in adults: an analysis of prognostic factors and timing of radiation. J Clin Oncol 1997;15:1294-301.

16. Smith DF, Hutton JL, Sandemann D, et al. The prognosis of primary intracerebral tumours presenting with epilepsy: the outcome of medical and surgical management. $J$ Neurol Neurosurg Psychiatry 1991;54:915-20.

17. Laws ER, Jr., Taylor WF. Clifton MB, Okazaki H. Neurosurgical management of low-grade astrocytoma of the cerebral hemispheres. J Neurosurg 1984;61:665-73. 
18. Vertosick FT, Jr., Selker RG, Arena VC. Survival of patients with well-differentiated astrocytomas diagnosed in the era of computed tomography. Neurosurgery 1991;28:496. 501.

19. Phitippon JH, Clemenceau SH, Fauchon FH, Foncin JF. Supratentorial low-grade astrocytomas in adults. Neurosurgery 1993;32:554-9.

20. Galanis E, Buckner JC, Novotny P, et at. Efficacy of neuroradiological imaging, neurological examination, and symptom status in follow-up assessment of patients with high-grade gliomas. J Neurosurg 2000;93:201-7.

21. Kelly PJ, Daumas-Duport C, Kispert DB, Kall BA, Scheithauer BW, Iltig JJ. Imaging-based stereotaxic serial biopsies in untreated intracranial glial neoplasms. I Neurosurg $1987 ; 66: 865-74$.

22. Silverman C, Marks JE. Prognostic significance of contrast enhancement in low-grade astrocytomas of the adult cerebrum. Rodiology 1981;139:211-3.

23. Kondziolka D, Lunsford LD, Martinez AJ. Unreliability of contemporary neurodiagnostic imaging in evaluating suspected adult supratentorial (low-grade) astrocytoma. I Neurosurg 1993; 79:533-6.

24. Barker FG, 2nd, Chang SM, Huhn SL, et al. Age and the risk of anaplasia in magnetic resonance-nonenhancing supratentorial cerebral tumors. Cancer 1997;80:936-41.

25. Scott JN, Brasher PM, Sevick RJ, Rewcastle NB, Forsyth PA. How often are nonenhancing supratentorial gliomas malignant? A population study. Neurology 2002;59:947.9.

26. De Witte $\mathrm{O}$, Levivier $M$, Violon $\mathrm{P}$, et al. Prognostic value positron emission tomography with [18F]fluoro-2-deoxy-D-glucose in the low-grade glioma. Neurosurgery 1996;39:470-6.

27. Nuutinen J, Sonninen P, Lehikoinen P, et al. Radiotherapy treatment planning and long. term follow-up with [(11)C]methionine PET in patients with low-grade astrocytoma. Int $J$ Radiat Oncol Biol Phys 2000;48:43-52.

28. Ogawa T, Kanno I, Shishido F, et al. Clinical value of PET with 18F-fluorodeoxyglucose and L-methyl-11C-methionine for diagnosis of recurrent brain tumor and radiation injury. Acto Radiol 1991;32:197-202.

29. Nelson SJ, Vigneron DB, Dillon WP. Serial evaluation of patients with brain tumors using volume MRI and 3D 1H MRSI. NMR Biomed 1999;12:123-38.

30. Mason W, MacDonald D. Low-grade gliomas. In: ChJ Vecht, ed. Neuro-oncology: Part II: Elsevier science BV, 1997: 33-60.

31. Whitton AC, Bloom HJ. Low grade glioma of the cerebral hemispheres in adults: a retrospective analysis of 88 cases. Int J Radiat Oncol Biol Phys 1990;18:783-6.

32. North CA, North RB, Epstein JA, Piantadosi S, Wharam MD. Low-grade cerebral astrocytomas. Survival and quality of life after radiation therapy. Cancer 1990;66:6-14.

33. McCormack BM, Miller DC, Budzilovich GN, Voorhees GJ, Ransohoff J. Treatment and survival of low-grade astrocytoma in adults-1977-1988. Neurosurgery 1992;31:636-42.

34. Shibamoto $Y$, Kitakabu $Y$, Takahashi $M$, et al. Supratentorial low-grade astrocytoma. Correlation of computed tomography findings with effect of radiation therapy and prognostic variables. Cancer 1993;72:190-5. 
35. Rajan B, Pickuth D, Ashley S, et al. The management of histologically unverified presumed cerebral gliomas with radiotherapy. Int $J$ Radiat Oncol Biol Phys 1994;28:405-13.

36. Firsching R, Tieben R, Schroder R, Stutzer R. Long-term prognosis of low grade astrocytoma. Zentralbl Neurochir 1994;55:10-5.

37. Berger MS, Deliganis AV, Dobbins J, Keles GE. The effect of extent of resection on recurrence in patients with low grade cerebral hemisphere gliomas. Cancer 1994;74:178491.

38. Janny $\mathrm{P}, \mathrm{Cure} \mathrm{H}, \mathrm{Mohr} \mathrm{M}$, et al. Low grade supratentorial astrocytomas. Management and prognostic factors. Cancer 1994;73:1937-45.

39. Nicolato A, Gerosa MA, Fina P, luzzolino P, Giorgiutti F, Bricolo A. Prognostic factors in low-grade supratentorial astrocytomas: a uni- multivariate statistical analysis in 76 surgically treated adult patients. Surg Neurol 1995;44:208-21; discussion 221-3.

40. Touboul E, Schlienger M, Buffat L, et al. Radiation therapy with or without surgery in the management of low - grade brain astrocytomas. A retrospective study of 120 patients. Bull Cancer Radiother 1995;82:388-95.

41. Piepmeier JM. Observations on the current treatment of low-grade astrocytic tumors of the cerebral hemispheres. J Neurosurg 1987;67:177-81.

42. Bahary JP, Villemure JG, Choi S, et al. Low-grade pure and mixed cerebral astrocytomas treated in the CT scan era. J Neurooncol 1996;27:173-7.

43. Schuurman PR, Troost D, Verbeeten B, Jr., Bosch DA. 5-year survival and clinical prognostic factors in progressive supratentorial diffuse "low-grade" astrocytoma: a retrospective analysis of 46 cases. Acta Neurochir 1997;139:2-7.

44. van Veelen ML, Avezaat CJ, Kros JM, van Putten W, Vecht CJ. Supratentorial low grade astrocytoma: prognostic factors, dedifferentiation, and the issue of early versus late surgery. J Neurol Neurosurg Psychiatry 1998;64:581-7.

45. Peraud A, Ansari H, Bise K, Reulen HJ. Clinical outcome of supratentorial astrocytoma WHO grade II. Acta Neurochir 1998; 140:1213-22.

46. Bauman G, Lote K, Larson D, et al. Pretreatment factors predict overall survival for patients with low- grade glioma: a recursive partitioning analysis. Int J Radiat Oncol Biol Phys 1999; 45:923-9.

47. Nakamura M, Konishi N, Tsunoda S, et al. Analysis of prognostic and survival factors related to treatment of low-grade astrocytomas in adults. Oncology 2000;58:108-16.

48. Arienti VM, Botturi A, Boiardi A, et al. Adult brain low-grade astrocytomas: survival after surgery and radiotherapy. Neurol Sci 2001;22:233-8.

49. Eyre HJ, Crowley JJ, Townsend JJ, et al. A randomized trial of radiotherapy versus radiotherapy plus CCNU for incompletely resected low-grade gliomas: a Southwest Oncology Group study. J Neurosurg 1993;78:909-14.

50. Karim ABMF, Maat B, Hatlevoll R, et al. A randomized trial on dose-response in radiation therapy of low-grade cerebral glioma: European Organization for Research and Treatment of Cancer (EORTC) Study 22844. Int J Radiat Oncol Biol Phys 1996; 36:549-56. 
51. Karim ABMF, Afra D, Cornu P, et al. Randomized trial on the efficacy of radiotherapy for cerebral low-grade glioma in the adult: European Organization for Research and Treatment of Cancer Study 22845 with the Medical Research Council study BRO4: an interim analysis. Int $J$ Rodiat Oncol Biol Phys 2002;52:316-24.

52. Shaw E, Arusell R, Scheithauer B, et al. Prospective randomized trial of low- versus highdose radiation therapy in adults with supratentorial low-grade glioma: initial report of a North Central Cancer Treatment Group/Radiation Therapy Oncology Group/Eastern Cooperative Oncology Group study. J Clin Oncol 2002;20:2267-76.

53. Pignatti $F$, van den Bent $M$, Curran $D$, et al. Prognostic factors for survival in adult patients with cerebral low-grade glioma. J Clin Oncol 2002;20:2076-84.

54. Piepmeier JM, Fried I, Makuch R. Low-grade astrocytomas may arise from different astrocyte lineages. Neurosurgery 1993;33:627-32.

55. Muller W, Afra D, Schroder R. Supratentorial recurrences of gliomas. Morphological studies in relation to time intervals with astrocytomas. Acta Neurochir 1977; 37:75-91.

56. Fried I, Kim JH, Spencer DD. Limbic and neocortical gliomas associated with intractable seizures: a distinct clinicopathological group. Neurosurgery 1994;34:815-23.

57. Vecht $\mathrm{CJ}$. Effect of age on treatment decisions in low-grade glioma. $J$ Neurol Neurosurg Psychiatry 1993;56:1259-64.

58. Klein M, Heimans JJ, Aaronson NK, et al. Effect of radiotherapy and other treatmentrelated factors on mid-term to long-term cognitive sequelae in low-grade gliomas: a comparative study. Lancet 2002;360:1361-8.

59. Quinn JA, Reardon DA, Friedman AH, et al. Phase II Trial of Temozolomide in Patients With Progressive Low-Grade Glioma. J Clin Oncol 2003;21:646-51.

60. Stupp R, Gander M, Leyvraz S, Newlands E. Current and future developments in the use of temozolomide for the treatment of brain tumours. Lancet Oncol 2001;2:552-60.

61. Recht LD, Lew R, Smith TW. Suspected low-grade glioma: is deferring treatment safe? Ann Neurol 1992;31:431-6.

62. Reijneveld JC, Sitskoorn MM, Klein M, Nuyen J, Taphoorn MJB. Cognitive status and quality of life in patients with suspected versus proven low-grade gliomas. Neurology 2001;56:618-23.

63. Krouwer HG, Davis RL, Silver P, Prados M. Gemistocytic astrocytomas: a reappraisal. J Neurosurg 1991;74:399-406.

64. MC Lendon RE, Enerline DS. Tien RT, Thorstad WL, Bruner JM. Tumors of central neuroepithelial origin. In: Bigner DD, Mc Lendon RE, Bruner JM, eds. Russell \& Rubinstein's pathology of tumors of the nervous system. 6 ed. London: Arnold, 1998: 307.573.

65. Prayson RA, Estes ML. Protoplasmic astrocytoma. A clinicopathologic study of 16 tumors. Am J Clin Pathol 1995;103:705-9.

66. Kim TS, Halliday AL, Hedley-Whyte ET, Convery K. Correlates of survival and the DaumasDuport grading system for astrocytomas. J Neurosurg 1991;74:27-37.

67. Kleihues P, Burger PC, Scheithauer BW. The new WHO classification of brain tumours. Brain Pathol 1993; 3:255-68. 
68. Giannini C, Scheithauer BW, Burger PC, et al. Cellular proliferation in pilocytic and diffuse astrocytomas. J Neuropathol Exp Neurol 1999;58:46-53.

69. Paulus W, Peiffer J. Intratumoral histologic heterogeneity of gliomas. A quantitative study. Cancer 1989;64:442-7.

70. Chandrasoma PT, Smith MM, Apuzzo ML. Stereotactic biopsy in the diagnosis of brain masses: comparison of results of biopsy and resected surgical specimen. Neurosurgery 1989;24:160-5.

71. Feiden W, Steude U, Bise K, Gundisch O. Accuracy of stereotactic brain tumor biopsy: comparison of the histologic findings in biopsy cylinders and resected tumor tissue. Neurosurg Rev 1991;14:51-6.

72. Daumas-Duport C. Histological grading of gliomas. Curr Opin Neurol Neurosurg 1992;5:924-31.

73. Cairncross JG, Macdonald DR. Successful chemotherapy for recurrent malignant oligodendroglioma. Ann Neurol 1988;23:360-4.

74. Coons SW, Johnson PC, Scheithauer BW, Yates AJ, Peart DK. Improving diagnostic accuracy and interobserver concordance in the classification and grading of primary gliomas. Cancer 1997; 79:1381-93.

75. Bruner JM. Neuropathology of malignant gliomas. Semin Oncol 1994;21:126-38.

76. McKeever PE, Strawderman MS, Yamini B, Mikhail AA, Blaivas M. MIB-1 proliferation index predicts survival among patients with grade II astrocytoma. J Neuropathol Exp Neurol 1998;57:931-6.

77. Schiffer D, Cavalla P, Chio A, Richiardi P, Giordana MT. Proliferative activity and prognosis of low-grade astrocytomas. J Neurooncol 1997;34:31-5.

78. Sallinen SL, Sallinen P, Haapasalo H, et al. Accumulation of genetic changes is associated with poor prognosis in grade II astrocytomas. Am J Pathol 1997;151:1799-807.

79. Wessels PH, Twijnstra A, Kessels AGH, et al. Gain of chromosome 7, as detected by in situ hybridization, strongly correlates with shorter survival in astrocytoma grade 2 . Genes Chromosomes Cancer 2002; 33:279-84.

80. Ito S, Chandler K, Prados $M$, et al. Proliferative potential and prognostic evaluation of low. grade astrocytomas. J Neurooncol 1994;19:1-9.

81. Hoshino T, Ahn D, Prados MD, Lamborn K, Wilson CB. Prognostic significance of the proliferative potential of intracranial gliomas measured by bromodeoxyuridine labeling. Int J Cancer 1993;53:550-5.

82. Onda K, Davis RL, Shibuya M, Wilson CB, Hoshino T. Correlation between the bromodeoxyuridine labeling index and the MIB-1 and $\mathrm{Ki}-67$ proliferating cell indices in cerebral gliomas. Cancer 1994;74:1921-6.

83. Louis DN, Edgerton S, Thor AD, Hedley-Whyte ET. Proliferating cell nuclear antigen and Ki67 immunohistochemistry in brain tumors: a comparative study. Acta Neuropathol (Berl) 1991:81:675-9. 
84. Saltinen PK, Haapasalo HK, Visakorpi T, et al. Prognostication of astrocytoma patient survival by Ki-67 (MIB-1), PCNA, and S-phase fraction using archival paraffin-embedded samples. J Pathol 1994;174:275-82.

85. Rey JA, Bello MJ, de Campos JM, Kusak ME, Ramos C, Benitez J. Chromosomal patterns in human malignant astrocytomas. Cancer Genet Cytogenet 1987;29:201-21.

86. Li J, Yen C, Liaw D, et al. PTEN, a putative protein tyrosine phosphatase gene mutated in human brain, breast, and prostate cancer. Science 1997;275:1943-7.

87. von Deimling A, Fimmers R, Schmidt MC, et at. Comprehensive allelotype and genetic anaysis of 466 human nervous system tumors. J Neuropathol Exp Neurol 2000;59:544-58.

88. Schlegel J, Scherthan H, Arens N, Stumm G, Kiessling M. Detection of complex genetic alterations in human glioblastoma multiforme using comparative genomic hybridization. $J$ Neuropathol Exp Neurol 1996;55:81-7.

89. Huang H, Colella S, Kurrer M, Yonekawa Y, Kleihues P, Ongaki H. Gene expression profiling of low-grade diffuse astrocytomas by CDNA arrays. Cancer Res 2000;60:6868-74.

90. Hopman AHN, Ramaekers FCS. Processing and staining of cell and tissue material for interphase cytogenetics. In: Robinson P, ed. Current protocols in cytometry. New York: John Wiley \& Sons, Inc, 1998: Chapter 8.5.1-8.5.2.

91. Cremer T, Lichter P, Borden J, Ward DC, Manuelidis L. Detection of chromosome aberrations in metaphase and interphase tumor cells by in situ hybridization using chromosome-specific library probes. Hum Genet 1988;80:235-46.

92. Jeuken JW, Sprenger SH, Wesseling P. Comparative genomic hybridization: practical guidelines. Diagn Mol Pathol 2002;11:193-203.

93. Darling JL, Warr TJ, Ashmore SM, Luxsuwong M, Revesz T. Non-isotopic molecular cytogenetics in neuro-oncology. Neuropathol Appl Neurobiol 1997;23:441-56.

94. Collins VP. Progression as exemplified by human astrocytic tumors. Semin Cancer Biol 1999;9:267-76.

95. Zhu Y, Parada LF. The molecular and genetic basis of neurological tumours. Nat ReV Cancer 2002;2:616-26.

96. Kleihues P, Ohgaki $\mathrm{H}$. Genetics of glioma progression and the definition of primary and secondary glioblastoma. Brain Pathol 1997;7:1131-1136.

97. Fuller GN, Bigner SH. Amplified cellular oncogenes in neoplasms of the human central nervous system. Mutat Res 1992;276:299-306.

98. James CD, Carlbom E, Dumanski JP, et al. Clonal genomic alterations in glioma malignancy stages. Cancer Res 1988;48:5546-51.

99. von Deimling A, Eibl RH, Ohgaki $\mathrm{H}$, et al. p53 mutations are associated with 17p allelic loss in grade II and grade III astrocytoma. Cancer Res 1992;52:2987-90.

100. Guha A, Feldkamp MM, Lau N, Boss G, Pawson A. Proliferation of human malignant astrocytomas is dependent on Ras activation. Oncogene 1997; 15:2755-65.

101. Hermanson M, Funa K, Koopmann J, et al. Association of loss of heterozygosity on chromosome $17 p$ with high platelet-derived growth factor alpha receptor expression in human malignant gliomas. Cancer Res 1996;56:164-71. 
102. Wernicke C, Thiel G, Lozanova T, Vogel S, Witkowski R. Numerical aberrations of chromosomes 1, 2, and 7 in astrocytomas studied by interphase cytogenetics. Genes Chromosomes Cancer 1997; 19:6-13.

103. Perry A, Tonk V, Mcintire DD, White CL. Interphase cytogenetic (in situ hybridization) analysis of astrocytomas using archival, formalin-fixed, paraffin-embedded tissue and nonfluorescent light microscopy. Am J Clin Pathol 1997;108:166-74.

104. Nishizaki T, Ozaki S, Harada K, et al. Investigation of genetic alterations associated with the grade of astrocytic tumor by comparative genomic hybridization. Genes Chromosomes Cancer 1998;21:340-6.

105. Hirose Y, Aldape KD, Chang S, Lamborn K, Berger MS, Feuerstein BG. Grade II astrocytomas are subgrouped by chromosome aberrations. Cancer Genet Cytogenet 2003;142:1-7.

106. Hurtt MR, Moossy J, Donovan-Peluso M, Locker J. Amplification of epidermal growth factor receptor gene in gliomas: histopathology and prognosis. I Neuropathol Exp Neurol 1992;51:84-90.

107. Oskam NT, Bijleveld EH, Hulsebos TJ. A region of common deletion in 22q13.3 in human glioma associated with astrocytoma progression. Int J Cancer 2000;85:336-9.

108. Ichimura K, Schmidt EE, Miyakawa A, Goike HM, Collins VP. Distinct patterns of deletion on $10 p$ and $10 q$ suggest involvement of multiple tumor suppressor genes in the development of astrocytic gliomas of different malignancy grades. Genes Chromosomes Cancer 1998:22:9-15.

109. Olopade OI, Jenkins RB, Ransom DT, et al. Molecular analysis of deletions of the short arm of chromosome 9 in human gliomas. Cancer Res 1992;52:2523-9.

110. Moulton T, Samara G, Chung WY, et al. MTS1/p16/CDKN2 lesions in primary glioblastoma multiforme. Am J Pathol 1995;146:613-9.

111. Nakamura $M$, Yang $F$, Fujisawa $H$, Yonekawa $Y$, Kleihues $P$, Ohgaki $H$. Loss of heterozygosity on chromosome 19 in secondary glioblastomas. J Neuropathol Exp Neurol 2000;59:539-43.

112. Fujisawa $H$, Kurrer $M$, Reis RM, Yonekawa $Y$, Kleihues $P$, Ohgaki $H$. Acquisition of the glioblastoma phenotype during astrocytoma progression is associated with loss of heterozygosity on 10q25-qter. Am J Pathol 1999;155:387-94.

113. Mollenhauer J, Wiemann S, Scheurlen W, et al. DMBT1, a new member of the SRCR superfamily, on chromosome $10 \mathrm{q} 25.3-26.1$ is deleted in malignant brain tumours. Nat Genet 1997;17:32-9.

114. Chozick BS, Pezzullo JC, Epstein MH, Finch PW. Prognostic implications of p53 overexpression in supratentorial astrocytic tumors. Neurosurgery 1994; 35:831-7.

115. Kraus JA, Bolln C, Wolf HK, et al. TP53 atterations and clinical outcome in low grade astrocytomas. Genes Chromosomes Cancer 1994;10:143-9.

116. Peraud A, Kreth FW, Wiestler OD, Kleihues P, Reulen HJ. Prognostic impact of TP53 mutations and P53 protein overexpression in supratentorial WHO grade II astrocytomas and oligoastrocytomas. Clin Cancer Res 2002;8:1117-24. 

17. Wessels PH, Hopman AHN, Ummelen MIJ, Krijne-Kubat B, Ramaekers FCS, Twijnstra A.
Differentiation between reactive gliosis and diffuse astrocytoma by in situ hybridization. Neurology 2001;56:1224-7.

118. Watanabe T, Nakamura M, Kros JM, et al. Phenotype versus genotype correlation in oligodendrogliomas and low- grade diffuse astrocytomas. Acta Neuropathol (Berl) 2002; 103:267-75.

119. Jeuken JW, Sprenger SH, Wesseling P, et al. Identification of subgroups of high-grade oligodendroglial tumors by comparative genomic hybridization. J Neuropathol Exp Neurol 1999;58:606-12.

120. Fuller $\mathrm{GN}$, Hess $\mathrm{KR}$, Rhee $\mathrm{CH}$, et al. Molecular classification of human diffuse gliomas by multidimensional scaling analysis of gene expression profiles parallels morphology-based classification, correlates with survival. 



\section{3}

\section{Chromosome aberrations as}

\section{detected by in situ hybridization}

differentiate between reactive

gliosis and astrocytoma grade II

Presented at the $52^{\text {nd }}$ annual meeting of the American Academy of Neurology, April 30th 2000, San Diego, USA.

Wessels PH, Hopman AHN, Ummelen MIJ, Krijne-Kubat B, Ramaekers FCS, Twijnstra A. Neurology 2001; 56: 1224-1227. 



\begin{abstract}
Histopathological diagnoses of stereotactic biopsy specimens underestimate tumor grade in approximately thirty percent of astrocytomas. In particular the diagnosis of samples from patients with astrocytoma grade II (A II) may be inconclusive due to extensive histopathological heterogeneity in these specimens. Our objective was to examine whether in situ hybridization (ISH) using chromosome specific DNA probes can be of additional value in this respect by detecting chromosomal aberrations in A II and thereby distinguish these from non-neoplastic reactive gliosis in stereotactic biopsy samples. The patient material consisted of 10 samples containing non-neoplastic reactive gliosis, 20 cases of $A$ II, and 13 cases of stereotactic samples in which the differentiation between reactive gliosis and A II was inconclusive. Numerical chromosomal aberrations for the chromosomes 1, 7, and 10 were evaluated by ISH applied to paraffin sections. No numerical chromosomal aberrations were detected in samples containing reactive gliosis. In the A II 16 out of 20 samples showed numerical chromosomal aberrations for one or more of the chromosomes investigated. In 4 out of 13 samples with an initially inconclusive tissue diagnosis the primary biopsy revealed numerical chromosomal aberrations. In three of these high-grade astrocytoma was diagnosed at a later stage.

We conclude that the detection of numerical chromosomal aberrations by ISH is a valuable additional tool in the distinction between A II and reactive gliosis.
\end{abstract}




\section{Introduction}

Due to small size and histopathological heterogeneity the tumor grade of diffuse astrocytoma is often underestimated in stereotactic biopsy specimens. Stereotactic biopsy samples are not representative of the tumor in $30 \%$ of astrocytomas as compared to gross resection specimens of astrocytomas. ${ }^{1,2}$ In particular in stereotactic biopsy samples from patients with astrocytoma grade II tissue diagnosis may be inconclusive. ${ }^{3}$

Astrocytoma grade II (A II) are frequently mixtures of neoplastic astrocytes and reactive gliosis, a proliferation of glioma cells, microglia and astrocytes in response to neural tissue damage. In an attempt to morphologically differentiate between a nonneoplastic or a neoplastic cause of astrocytic proliferation different methods have so far been applied, such as the intra-operative cytological wet smear technique, acridine orange staining, the AgNOR-technique, and additional immunohistochemical staining for P53- and $\mathrm{Ki}$-67- antigens. ${ }^{48}$

In most samples with reactive gliosis P53 immunoreactivity is absent, and Ki-67 labeling index is less than 1 percent. However, $10 \%$ of these non-malignant lesions show P53 immunoreactivity, and occasionally exhibit a Ki-67 labeling index higher than $3 \%$. ${ }^{7.8}$

Cytogenetic procedures can be of additional value in the differentiation between reactive gliosis and astrocytoma. However with most cytogenetic techniques only sporadic chromosomal aberrations are detected in A II besides loss of 17p and mutations of p53-gene. ${ }^{9}$ The in situ hybridization (ISH)-technique allows a more frequent detection of chromosomal aberrations in tumors while normal and nonneoplastic tissues are disomic. ${ }^{10-13}$

The purpose of this study was therefore to determine whether the ISH technique offers additional diagnostic value by detecting tumor cells in areas of astrocytomas which are not typical enough to allow a morphological diagnosis. ISH analysis in these inconclusive cases was compared with samples containing reactive gliosis on the one hand, and cases with evident A II on the other hand.

All samples were investigated with (sub-)centromere probes for the chromosomes 1, 7 and 10. Chromosome 1 has been shown to present a sensitive general marker for aneusomy ${ }^{14}$, while gain of chromosome 7 and loss of chromosome 10 are frequent events in astrocytomas. ${ }^{15.16}$ The ISH results were compared with the (tumor) cell proliferation (Ki-67) index, which is considered to have additional value in the differentiation between non-neoplastic and neoplastic astrocytic proliferation. 


\section{Material and methods}

\section{Patient material and clinical data}

The formalin fixed, paraffin- embedded archival material consisted of three groups of tissue samples:

1. Reactive gliosis from post-mortem examination in patients who died from a neurological non-neoplastic cause $(n=10)$, i.e. brain infarction $(n=5)$, hemorrhagic infarction $(n=1)$, traumatic hemorrhage $(n=2)$, and hypoxic encephalopathy $(n=2)$.

2. Astrocytoma grade II (A II; $\mathrm{n=20}$ ), according to the WHO classification. ${ }^{17}$

3. Stereotactic biopsy samples $(n=13)$ with an inconclusive tissue diagnosis, i.e. no differentiation between non-neoplastic reactive gliosis and A II.

Material was retrieved from the files of the Departments of Pathology from the University Hospitals of Maastricht and Groningen, the Atrium Hospital in Heerlen, and the Medical Spectrum Twente in Enschede, The Netherlands. Clinical data with regard to interval of tumor progression, defined as histological or radiological evidence of progression to higher grade astrocytoma, were available.

In situ hybridization: procedure, probes and evaluation.

\section{Pretreatment of the sections}

ISH was performed using a recently optimized protocol. ${ }^{18}$ Five-micron thick sections from selected paraffin blocks were deparaffinised in xylol, dehydrated in an ascending ethanol series, and pretreated in $85 \%$ formic acid containing $0.3 \% \mathrm{H} 2 \mathrm{O} 2$ for 20 minutes at room temperature. After dehydration in $0.01 \mathrm{M} \mathrm{HCl}$ in $70 \%$ ethanol, followed by washings in following steps of $70 \%, 90 \%$, and $100 \%$ ethanol, the specimen were incubated at $80^{\circ} \mathrm{C}$ in $1 \mathrm{M}$ sodium thiocyanate ( $\mathrm{NaSCN}$ ). Proteolytic digestion was done in $4 \mathrm{mg} / \mathrm{ml}$ pepsin (from porcine stomach: 2500-3500 units per $100 \mathrm{mg}$ protein: Sigma, St Louis, USA) for 10 minutes at $37^{\circ} \mathrm{C}$ in $0.02 \mathrm{M} \mathrm{HCl}$ to increase tissue permeability. After dehydration in acidified ethanol series, the tissues were fixated in $1 \%$ formaldehyde in phosphate-buffered saline (PBS) for 15 minutes.

\section{Probes}

The probes were specific for the heterochromatin (sub)centromere region of chromosome 1 (1q12, pUC 1.77; Cooke and Hindley $\left.{ }^{14}\right)$, the alphoid region of 
chromosome 7 (p7t1, Waye et $\left.\mathrm{al}^{19}\right)$, and the pericentromere region of chromosome 10 (D10z1, Devilee et $\mathrm{al}^{20}$ ).

\section{In situ hybridization (ISH) procedure}

The probes were hybridized under a coverslip in a mixture containing $2 \times$ standard saline citrate (SSC), $60 \%$ formamide, $10 \%$ dextran sulphate, and $0.2 \mathrm{mg} / \mathrm{ml}$ herring sperm DNA. After denaturation at $80^{\circ} \mathrm{C}$ for 5 minutes the slides were placed in a moist chamber and incubated overnight at $37^{\circ} \mathrm{C}$. The slides were then washed twice in $2 \mathrm{X}$ SSC/ $0.05 \%$ Tween at $45^{\circ} \mathrm{C}$, and in 4 X SSC/ $0.05 \%$ Tween at room temperature.

The biotin-labeled DNA probes were indirectly detected by an immunoperoxidase enzymatic precipitation reaction. The slides were incubated for 30 minutes at room temperature with mouse-antibiotin monoclonal antibody, followed by biotinylated horse-anti-mouse, and finally with avidin-biotin-peroxidase complex (all reagents from Vector Laboratories, Burlingame, CA, USA). Finally $0.1 \mathrm{M}$ diaminobenzidine (DAB, Sigma, St Louis, MO, USA) in PBS containing $0.03 \% \mathrm{H}_{2} \mathrm{O}_{2}$ was applied for visualisation of the peroxidase activity. Nuclear counterstaining was done with hematoxylin or alternatively with 4,6-diamino-phenylindol (DAPI, Sigma, St.Louis, MO, USA).

\section{Signal evaluation and interpretation}

The number of signals per nucleus was counted in at least 200 non-overlapping nuclei, following criteria proposed by Hopman et at. ${ }^{21}$ Due to truncation of cell nuclei the percentage of cells with no or one ISH signal differs between experiments, but has a maximum of $25 \%$ in tissue sections. ${ }^{21}$ Therefore monosomy was defined as > $25 \%$ of nuclei with no or one signal per nucleus.

All histological areas classified as genetically disomic contained only sporadic nuclei exhibiting more than 2 signals. We could not determine whether or not the rare aneusomic cells should be considered as genetically aberrant or result from nuclear overlap. In normal tissue this total fraction of nuclei does not exceed 5\%. ${ }^{22.23}$ Therefore nuclei were only classified trisomic if $>5 \%$ of nuclei contained three or more signals. Nuclei containing four and more than four signals were defined as tetrasomic and polysomic, respectively.

Brightfield microscopy was performed using a Leica-DMBRE microscope equipped with a filterset for DAPI. Images were captured and stored with the Metasystem Image Pro System (Heidelberg, Germany), using a charge-coupled device (CCD) camera. 


\section{Ki-67 immunostaining}

In all samples the proliferation status was assessed as the Ki-67 immunostaining index by using the mouse monoclonal Mib-1 antibody. Endogenous peroxidase was blocked with $0.3 \% \mathrm{H}_{2} \mathrm{O}_{2}$ in methanol for 20 minutes. Antigen retrieval was achieved by treatment with $10 \mathrm{mM}$ citrate buffer $(\mathrm{pH} 6.0)$ in a domestic microwave oven for 10 minutes at 700W. The first layer consisted of Mib-1 antibody 1:12 (Immunotech S.A. Marseille, France) in PBS containing $1 \%$ bovine serum albumin. The second layer antibody was biotin-labeled horse antimouse $\lg$ 1:200 in PBS/Tween containing $4 x$ normal goat serum. The third layer consisted of avidin-biotin complex applied for 1 hour (Vector Laboratories, Burlingame, CA, USA). Signals were developed using diaminobenzidine $/ \mathrm{H}_{2} \mathrm{O}_{2}$. The Mib-1 positive cells were counted in at least 200 nuclei in the areas with the highest immunopositivity.

\section{Results}

\section{Reactive gliosis}

Neuropathological revision of these 10 cases showed an increase in astrocytic cellularity without neoplastic features. With ISH, using probes for the chromosomes 1, 7 and 10, all evaluable ( $87 \%$ ) tests revealed disomy. Very sporadic nuclei with three signals were seen, but none of the samples fulfilled the criteria for trisomy. In one sample with reactive gliosis the Ki-67 labeling index was $3.5 \%$, while in the other samples it did not exceed $1 \%$.

\begin{tabular}{|c|c|c|c|c|c|c|}
\hline \multirow{2}{*}{ Diagnosis } & \multirow{2}{*}{$\mathrm{N}$} & \multicolumn{3}{|c|}{$\begin{array}{l}\text { Number of samples with numerical } \\
\text { chromosomal aberrations ( } \% \text { Total) }\end{array}$} & \multirow[t]{2}{*}{$\begin{array}{l}\text { Aberrant for one or } \\
\text { more chromosomes }\end{array}$} & \multirow[t]{2}{*}{$\begin{array}{l}\mathrm{Ki} .67 \mathrm{LI} \\
\text { (\%cells/range) }\end{array}$} \\
\hline & & Chr.1 & Chr.7 & Chr.10 & & \\
\hline Gliosis & 10 & 0 & 0 & 0 & 0 & $<1(<1.3)$ \\
\hline A II & 20 & $12(60 \%)$ & $13(65 \%)$ & $10(50 \%)$ & $16(80 \%)$ & $2.1(<1.9)$ \\
\hline Inconclusive & 13 & 3 (23\%) & $4 \quad(31 \%)$ & $1 \quad(8 \%)$ & $4(31 \%)$ & $2(<1-10)$ \\
\hline
\end{tabular}

TABLE 1. Summarized results of numerical chromosomal aberrations and $\mathrm{Ki}-67$ labeling index (LI) for the three investigated patient groups. 

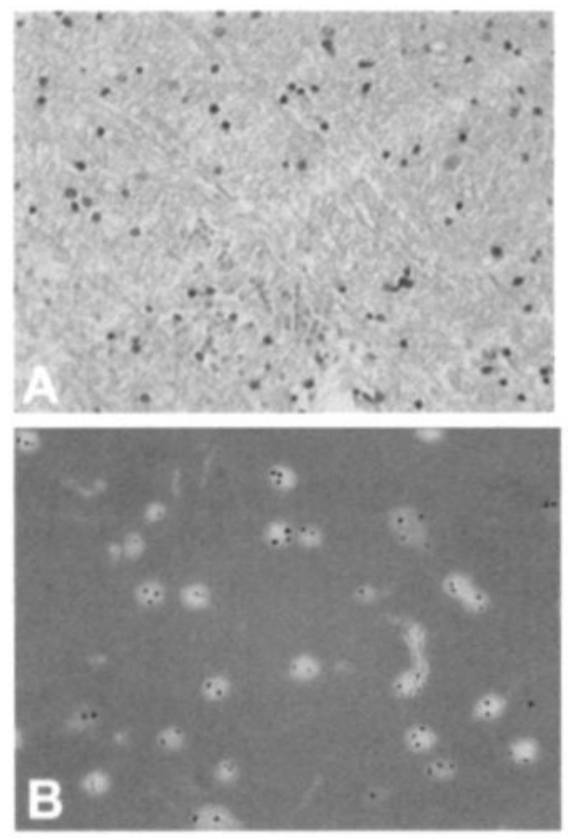

FIGURE 1. Routine microscopy (A) and in situ hybridization (B) with a probe for chromosome 7 in a sample with an inconclusive tissue diagnosis showing frequent nuclei with three or more signals

\section{Astrocytoma grade II}

Revision revealed 18 fibrillary and 2 gemistocytic A II. The mean age of the patients was 39.9 years (range: 24.68 years) and the median interval to tumor progression was 35 months. The ISH results are summarized in Table 1. Numerical chromosomal aberrations for one or more of the chromosomes investigated were present in $80 \%$ of the A II: for chromosome 1 in 60\%, for chromosome 7 in 65\%, and chromosome 10 in $56 \%$ of the samples. Only one sample (case 4) showed monosomy for the chromosomes 1 and 7. All other aberrations comprised trisomy, tetrasomy and polysomy. Case 1 showed focal areas with clustering of nuclei with trisomy and tetrasomy. In all other samples nuclei with abnormal hybridization signals were scattered throughout the preparation. The mean $\mathrm{Ki}-67$ labeling index in the astrocytomas was $2.1 \%$ (range <1-9).

\section{Cases with inconclusive diagnosis}

All samples with inconclusive tissue diagnosis were stereotactic biopsy specimens in which it was not possible to distinguish between reactive gliosis and A II on basis 
ofroutine histology. Revision of one sample, derived from a patient with a suspected recurrent astrocytoma after radiotherapy, revealed endothelial cell proliferation and necrosis. This we considered non-neoplastic radiation damage. In all other samples, in which microscopy revealed a mild increase in astrocyte cellularity and pleiomorphy, neuropathological revision agreed with the initial inconclusive diagnosis. ISH results and the Ki-67 labeling index are shown in Table 2.

According to follow-up data the samples could be divided into three groups:

1. Samples in which astrocytoma was diagnosed at a later stage (cases 1.7): in 3 of these 7 samples the primary biopsy already showed numerical chromosomal aberrations (Figure 1). Ki-67 labeling indices of these samples were 1, 10, and 5\% respectively. In case 7 no tissue confirmation of a malignancy was obtained but astrocytoma grade IV (A IV) was diagnosed by combination of histopathology and radiological progression of the space-occupying lesion.

2. Samples in which the follow-up period of the patients was too short and where second biopsy or resection was deferred (cases 8-11): In case 8 the primary biopsy showed numerical chromosomal aberrations for the chromosomes 1 and 7. The $\mathrm{Ki}$ 67 labeling index of this sample was less than 1\%.

3. Samples in which a non-neoplastic diagnosis was made at a later stage (cases 12. 13): Case 12 showed no numerical chromosomal aberrations and case 13 was not evaluable for ISH due to cell lysis.

\section{Discussion}

In the underlying study we show that the ISH technique, applying chromosome specific probes to routine processed brain tissue samples, allows the efficient distinction of reactive gliosis from A II. Since the separation of these two histomorphological entities is often difficult this finding is of clinical relevance.

No samples with reactive gliosis showed chromosomal aberrations, while $80 \%$ of the samples containing evident A II were classified as genetically aberrant for the chromosomes 1, 7 and / or 10. The normal findings in the non-neoplastic reactive gliosis group coincide with the few previous ISH studies concerning normal ${ }^{23}$ and gliotic brain tissue. ${ }^{24}$ With classical karyotyping trisomy 7 was reported to occur apparently normal brain cells probably due to a culture artifact. ${ }^{25}$ 


\begin{tabular}{|c|c|c|c|c|c|}
\hline \multirow[t]{2}{*}{ Case } & \multicolumn{3}{|c|}{ Numerical chromosome aberrations ( $\%$ Nuclei) } & \multirow{2}{*}{$\begin{array}{l}\text { Ki-67 LI } \\
\text { (\% cells) }\end{array}$} & \multirow[t]{2}{*}{ Follow-up } \\
\hline & Chromosome 1 & Chromosome 7 & Chromosor ne 10 & & \\
\hline & & & & & Malignant progression \\
\hline 1 & $\operatorname{Tri}(10 \%)$ & $\operatorname{Tri}(10 \%)$ & Tri (5\%) & 5 & Post-mortem: A IV, 10 months \\
\hline 2 & $\operatorname{Tri}(21 \%)$ & Tri (19\%) Tetra (11\%) Poly (1\%) & D & 1 & Resection: A III, 5 months \\
\hline 3 & D & $\operatorname{Tri}(25 \%)$ & D & 10 & Second biopsy: A IV, 2 months \\
\hline 4 & D & D & D & $<1$ & Resection: AA, 4 months \\
\hline 5 & D & D & D & $<1$ & Second biopsy: A IV, 1 month \\
\hline 6 & D & D & NE & $<1$ & Second biopsy: A IV, 40 months \\
\hline 7 & D & D & D & 4 & MRI, 35 months \\
\hline & & & & & No progression in time followed \\
\hline 8 & Tri $(10 \%)$ & Tri (32\%) Tetra (9\%) & NE & $<1$ & 4 months \\
\hline 9 & D & D & NE & $<1$ & 20 months \\
\hline 10 & D & D & D & $<1$ & 6 months \\
\hline 11 & D & D & D & $<1$ & 22 months \\
\hline & & & & & Non-malignant diagnosis \\
\hline 12 & D & D & D & $<1$ & Multiple sclerosis \\
\hline 13 & NE & NE & NE & NE & Radiation necrosis \\
\hline
\end{tabular}

TABLE 2. In situ hybridization results and $\mathrm{Ki-67}$ labeling index in samples $w_{\text {it }}$ th uncertain tissue diagnosis.

Abbreviations and symbols: $D=$ Disomy; Tri = Trisomy; Tetra $=$ Tetrasomy; Roly $=$ Polysomy; NE $=$ Not evaluable; $A$ III $=$ astrocytoma grade III; A IV = astrocytoma grade IV; MRI = Progression on MRI; Ki-67 LI = Ki-67 Labeling Index 
Genetic studies concerning chromosomal aberrations in A II involve mainly classical karyotyping ${ }^{15.16}$ and flow cytometry and mostly show diploid cells in A $11{ }^{26}$ In cell lines of these malignancies low-grade diffuse astrocytomas chromosomal aberrations were however found, such as trisomy for chromosome 7 and loss of one of the sex chromosomes. The aberrations are similar to those found in high-grade astrocytomas but occur in a very low frequency in A $11 .{ }^{15.16}$ With molecular genetic techniques, such as loss of heterozygosity ( $\mathrm{LOH}$ )- single-strand conformation polymorphism (SSCP)studies, and micro-satellite-analyses, again genotypic alterations in A II are sporadically detected, while occurring at a higher frequency in astrocytomas grade III and IV. ${ }^{2}$ With the ISH-technique chromosomal aberrations can be found more efficiently as compared to classical karyotyping or $\mathrm{LOH}$ studies because both metaphasic and interphasic cells are evaluated. Earlier ISH-studies on small series of A II already revealed hyperdiploid cells, gain of chromosome 1 and 7 , loss of chromosome 10, and aberrations of chromosome $17 .^{10-13}$ By using three chromosome probes with singletarget ISH analysis we could detect high percentages of aneusomic cells in most A II.

In four samples with an initial inconclusive tissue diagnosis aneusomies were detected by ISH. Of these four cases three showed rapid progression to A IV. This may however also suggest that in these cases, where the differential tissue diagnosis was to choose between reactive gliosis and A II, the patients most probably suffered from A IV, which were not detected at first diagnosis due to sampling errors. In the fourth case no progression was seen after 4 months of follow-up. Because the high frequency of genetic aberrations in this case the patient is clinically monitored on a regular basis.

Our findings indicate that the detectability of genotypic alterations extends well beyond the microscopical border of astrocytomas. ISH for detection of chromosome aberrations also seems more sensitive than Ki-67 immunocytochemistry. In 2 of the 4 inconclusive cases high $\mathrm{Ki}-67$ labeling indices were found, which supports the highmalignant character of these lesions. However in the 2 other lesions Ki-67 levels were low, suggesting that this marker has a lower sensitivity in the detection of lesions with a malignant clinical course as compared to the ISH-technique.

We conclude that numerical chromosomal aberrations for the chromosomes 1, 7 and 10 detected by $\mathrm{ISH}$, can distinguish between non-neoplastic tissue proliferation and astrocytoma. The ISH procedure therefore has additional value in the differential diagnosis of reactive gliosis versus A II. 


\section{References}

1. Chandrasoma PT, Smith MM, Apuzzo ML. Stereotactic biopsy in the diagnosis of brain masses:

2. Comparison of results of biopsy and resected surgical specimen. Neurosurgery 1989; 24: 160-165.

3. Ostertag CB, Mennel HD, Kiessling M. Stereotactic biopsy of brain tumors. Surg Neurol 1980; $14: 275-283$.

4. Gaudin PB, Sherman ME, Brat DJ, Zahurak M, Erozan YS. Accuracy of grading gliomas on CT-guided stereotactic biopsy: a survival analysis. Diogn Cytopathol 1997; 17 : 461-466.

5. Allegranza A. Cyto-histological diagnosis on wet smears of neurosurgical biopsies. J Neurosurg Sci 1989; 33: 27-29.

6. Sarnat HB, Curry B, Rewcastle NB, Trevenen CL. Gliosis and glioma distinquished by acridine orange. Can J Neurol Sci 1987; 14: 31-35.

7. Louis DN, Meehan SM, Ferrante RJ, Hedley-White ET. Use of the silver-nucleolar organizer region (AgNOR) technique in the differential diagnosis of central nervous system neoplasia. J Neuropathol Exp Neurol 1992; 51: 150-157.

8. Bigio EH, Colvin SM, Mickey BE, White CL, Rushing EJ. Radiation change versus recurrent astrocytoma: diagnostic utility of the proliferation index? J Neurooncol 1999; 41: 55-63.

9. Yaziji H, Massarani-Wafai R, Gujrati M, Kuhns JG, Martin AW, Parker JC Jr. Role of p53 immunohistochemistry in differentiating reactive gliosis from malignant astrocytic lesions. Am J Surg Pathol 1996; 20: 1086-1090.

10. Von Deimling A, Eibl Rh, Ohgaki H, et al. P53 mutaions are associated with 17p allelic loss in grade II and III astrocytomas. Cancer Res 1992; 52; 2987-2990.

11. Rosso SM, Van Dekken H, Krisnadath KK, Alers JC, Kros JM. Detection of chromosomal changes by interphase cytogenetics in biopsies of recurrent astrocytomas and oligodendrogliomas. J Neuropathol Exp Neurol 1997; 56: 1125-1131.

12. Campomenosi P, Ottagio L, Moro F, et al. Study on aneuploidy and p53 mutations in astrocytomas. Cancer Genet Cytogenet 1996, 88; 95-102.

13. Wernicke C, Thiel G, Lozanova T, Vogel S, Witkowski R. Numerical aberrations of chromosomes 1, 2, and 7 in astrocytomas studied by interphase cytogenetics. Genes Chromosom Cancer 1997; 19: 6-13.

14. Perry A, Tonk V, Mc Intire DD, White, CL. Interphase cytogenetic analysis of astrocytomas using archival, formalin-fixed, paraffin-embedded tissue and non-fluorescent light microscopy. Am J Clin Pathol 1997; 108: 166-174.

15. Cooke HJ, Hindley J. Cloning of human satellite III DNA: different components are on different chromosomes. Nucleic Acid Res 1979; 6: 3177-3197.

16. Rey JA, Bello MJ, De Campos JM, Kusak E, Moreno S. Chromosomal composition of a series 22 human low-grade gliomas. Cancer Genet Cytogenetics 1987; 29: 223-237. 
17. Bigner SB, Mark J, Bigner DD. Cytogenetics of human brain tumors. Cancer Genet Cytogenet 1990; 47: 141-154.

18. Waye JS, England SB, Willard HF. Genomic organisation of alpha satellite DNA on human chromosome 7: evidence for two distinct alphoid domains on a single chromosome. Mol Cell Biol 1987; 7: 349-356.

19. Kleihues P, Burger PC, Scheithauer BW, Histological typing of tumors of the central nervous system, 2nd edition, New York, Berlin: Springer-Verlag, 1993.

20. Hopman AHN, Ramaekers FCS. Processing and staining of cell and tissue material for interphase cytogenetics. In: Robinson P ed. Current protocols in cytometry. New York: John Wiley \& Sons Inc, 1998: Chapter 8.5.1.-8.5.22.

21. Devilee P, Kievits T, Waye JS, Pearson PL, Willard HF. Chromosome- specific alpha satellite DNA: isolation of a polymorphic alphoid repeat from human chromosome 10. Genomics 1988; $3: 1$-7.

22. Hopman AHN, Poddighe P, Moesker O, Ramaekers FCS. Interphase cytogenetics: an approach to the detection of genetic aberrations in tumours. In: Harrington CS, Mc Gee J O'D. Diagnostic molecular pathology, vol 1. Oxford: IRL. Press, 1992: 141-167.

23. Arnoldus EP, Wolters LB, Voormolen JH, et al. Interphase cytogenetics: a new tool for the study of genetic changes in brain tumors. J Neurosurg 1992; 76: 997-1003.

24. Dalrymple SJ, Herath JF, Borell TJ, Moertel CA, Jenkins RB. Correlation of cytogenetic and fluoresence in situ hybridization (FISH) studies in normal and gliotic brain. J Neuropothol Exp Neurol 1994; 53: 448.456

25. Arnoldus EPJ, Noordermeer IA, Peters ACB, Raap AK, Van der Ploeg M. Interphase cytogenetics reveals somatic pairing of chromosome 1 centromeres in normal brain tissue, but no trisomy 7 or sex chromosome loss. Cytogen Cell Genet 1991; 56: 214-216.

26. Heim S, Mandahl N, Jin Y, Lindstrom E, Salford LG, Mittelman F. Trisomy 7 and sex chromosome loss in human brain tissue. Cytogenet Cell Genet 1989; 52: 136-138.

27. Varvruch j, Nordenskjold B, Carstensen J, Enestrom S. Prognostic value of flow cytometry and correlation to some conventional prognostic factors: a retrospective study of archival specimens of 134 astrocytomas. J Neurosurg 1996; 85: 146-151.

28. Von Deimling A, Fimmers R, Schmidt MC, et at. Comprehensive allelotyping and genetic analysis of 466 human nervous system tumors. J Neuropathol Exp Neurol 2000; 59: 544 558. 



\section{4}

\section{Gain of chromosome 7 as detected}

by in situ hybridization correlates

with shorter survival in

astrocytoma grade II

Wessels PH, Twijnstra A, Ummelen MIJ,

Krijne-Kubat B, Ramaekers FCS, Hopman AHN.

Genes Chromosomes Cancer 2002; 33: 279-284. 



\begin{abstract}
The clinical course of astrocytoma grade $I I$ is highly variable and not reflected by morphological characteristics. Eartier studies in small series of astrocytoma grade II (A II) suggest that in situ hybridization (ISH) with chromosome specific DNA probes allows a frequent detection of aneusomy 1, trisomy 7, and monosomy 10. However, the role of trisomy 7 in astrocytoma carcinogenesis is disputed because of its presence in nonneoplastic brain tissue as detected by karyotyping. Our objective was to investigate if a correlation between chromosomal aberrations and survival was present in a series of 47 cases of A II. The tissues were evaluated for numerical aberrations of chromosomes 1, 7 and 10 by ISH. Chromosomal aberrations were detected in $68 \%$ of A II. Trisomy/polysomy 7 was observed in 31 cases (66\%), and in 22 of these (47\%) a high percentage of this numerical aberration was seen. Only 11 of these 22 cases also revealed aberrations for 1 and/or 10. No, or only very low frequencies, of cells with aberrations were detected in non-neoplastic control samples. Using Kaplan Meier analysis, trisomy/polysomy 7 correlated significantly with shorter survival. Hence, as determined by ISH, trisomy/polysomy 7 is absent in non-neoplastic brain tissue and is frequently detected in A II, correlating with the malignant progression of the disease.
\end{abstract}




\section{Introduction}

Genotypic characterization of astrocytoma grade II (A II) is not only important in understanding carcinogenesis, but might also offer prognostic information. Such prognostic information may help to resolve the controversy that exists with regard to the optimal treatment of A II. So far, only few studies investigated the correlation between cytogenetic aberrations and the clinical course of $\mathrm{A} \mathrm{II.}{ }^{1-3}$ Using classical karyotyping Kimmel et al ${ }^{4}$ showed that astrocytomas with clonal abnormalities had a shorter survival compared to astrocytomas without these abnormalities, however their group of A II was too small for separate analysis.

The most frequently reported genetic aberrations in A II include mutation of the p53. gene, loss of heterozygosity (LOH) of chromosome arm $17 p$ and trisomy 7. ${ }^{5.6}$ No correlation between p53-gene mutations and survival of A II patients was found.' Previous studies in small series of A II suggest that in situ hybridization (ISH) and comparative genomic hybridization (CGH) allow a frequent detection of chromosomal aberrations, such as gain of chromosomes 1 and 7 , loss of chromosome 10, and hyperdiploidy (Table 1), ${ }^{2 \cdot 3}, 7 \cdot 14$ Only two of these investigators correlated the cytogenetic results with the clinical course of $A U^{2-3}$ Sallinen et $a^{3}$ suggested a possible prognostic value of $\mathrm{CGH}$ in a series of $11 \mathrm{~A} \mathrm{II}$. Perry et $\mathrm{al}^{2}$ concluded that a deletion of chromosome 10 was of prognostic value when studying the total spectrum of

\begin{tabular}{|c|c|c|c|}
\hline $\begin{array}{l}\text { Method and } \\
\text { chromosomes examined }\end{array}$ & $\begin{array}{l}\text { Number of } \\
\text { A ll cases }\end{array}$ & $\begin{array}{l}\text { Chromosome aberrations } \\
\text { detected }\end{array}$ & Reference \\
\hline ISH 10,17 & 11 & $-10,-17,+17$ & Campomenosi et al ${ }^{7}$ \\
\hline ISH $7,10, X, Y$ & 10 & $+7,-10$ & Liu et $\mathrm{al}^{8}$ \\
\hline ISH 7,10,3 & 11 & $+7,-10$ & Perry et al ${ }^{2}$ \\
\hline ISH $1,7,10,17, X, Y, 1 p 36$ & 4 & +7 , Aneuploidy & Rosso et al ${ }^{9}$ \\
\hline ISH 7,10 & 3 & Tetrasomy 7 and 10 & Steilen-Gimbel et at ${ }^{10}$ \\
\hline ISH $1,2,7,1 \mathrm{p} 36$ & 9 & $+1,-1 \mathrm{p} 36,+7$ & Wernicke et al " \\
\hline $\mathrm{CGH}$ & 9 & $+8 q$ & Nishizaki et al ${ }^{12}$ \\
\hline $\mathrm{CGH}$ & 11 & $-1 p,+1$ pter $,+7 q,+8 q,-10$ & Saltinen et al ${ }^{13}$ \\
\hline $\mathrm{CGH}$ & 10 & $+7,+7 q,+8 q$ & Schrock et al ${ }^{14}$ \\
\hline $\mathrm{CGH}$ & 10 & $-5 p,+8 q,+12 p,+19 p,-x p$ & Weber et al ${ }^{15}$ \\
\hline
\end{tabular}

TABLE 1. Summary of results in the literature of in situ hybridization (ISH) and comparative genomic hybridization (CGH) studies in adult astrocytoma grade II. For CGH the most frequent aberrations are listed. 
astrocytomas, while trisomy 7 showed no significant correlation with post-operative survival.

The role of trisomy 7 in carcinogenesis of astrocytomas is controversial, given the finding that this aberration has been detected in cultured, histologicaly non-malignant, brain tissues. ${ }^{15.16}$ In contrast, trisomy 7 has not been detected in normal and gliotic brain tissues by $15 \mathrm{HH}{ }^{17-18}$

The objective of this study was to investigate the prognostic value of chromosome 7 aberrations in A II. The ISH technique was applied to routinely processed, paraffin. embedded, biopsy and resection samples, allowing a precise correlation of the genetic constitution of cells with their histological features.

\section{Material and methods}

\section{Patient material}

Forty-seven biopsy and resection samples diagnosed as astrocytoma grade II (A II), or supratentorial low-grade diffuse astrocytoma, were collected from the files of the Departments of Pathology of the University Hospitals of Maastricht and Groningen, and

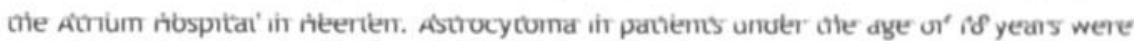
excluded. The samples were revised according to the WHO classification. ${ }^{19}$ From the patient records the overall survival was assessed. As controls, ten samples with nonneoplastic reactive gliosis were examined (see also reference 20 ). These samples were derived at post-mortem examination from patients who died from a non-neoplastic neurological cause, i.e. brain infarction $(n=5)$, hemorrhagic infarction $(n=1)$, traumatic hemorrhage $(n=2)$, and hypoxic encephalopathy $(n=2)$.

\section{In situ hybridization protocol}

The most representative paraffin blocks were selected from the $47 \mathrm{~A}$ II. Five micron thick sections were cut and pretreated according to a recently optimized protocol. ${ }^{21}$ After deparaffinization in xylol, and dehydration in ethanol series, the tissues were pretreated in $85 \%$ formic acid containing $0.3 \% \mathrm{H}_{2} \mathrm{O}_{2} 20$ minutes at room temperature. After dehydration in an acidified ethanol series, the specimens were incubated at $80^{\circ} \mathrm{C}$ in $1 \mathrm{M}$ sodium thiocyanate ( $\mathrm{NaSCN}$ ). Proteolytic digestion was performed in $4 \mathrm{mg} / \mathrm{ml}$ pepsin (from porcine stomach: 2500-3500 units per $100 \mathrm{mg}$ protein: Sigma, St Louis, USA) for 10 minutes at $37^{\circ} \mathrm{C}$ in $0.02 \mathrm{M} \mathrm{HCl}$. After dehydration in an acidified ethanol series the tissues were fixed in $1 \%$ formaldehyde in phosphate-buffered saline (PBS) for 15 minutes, followed by five subsequent washing steps in PBS and double-distilled 
water. In situ hybridization (ISH) was performed as described eartier (Hopman et at., 1998). The DNA probes used were specific for the heterochromatin (sub)-centromere region of chromosome 1 (1q12, pUC 1.77; Cooke and Hindley ${ }^{22}$ ), the alphoid region of chromosome 7 (p7t1; Waye et $\left.\mathrm{al}^{23}\right)$, and the pericentromere region of chromosome 10 (D10Z1; Devilee et $\mathrm{al}^{24}$ ). After denaturation at $80^{\circ} \mathrm{C}$ for 5 minutes hybridization was performed overnight at $37^{\circ} \mathrm{C}$ under a coverslip in a mixture containing $2 \times$ standard saline citrate (SSC), $60 \%$ formamide, $10 \%$ dextran sulphate, and $0.2 \mathrm{mg} / \mathrm{ml}$ herring sperm DNA. Post-hybridization washes included two washes in $2 \times \mathrm{SSC} / 0.05 \%$ / Tween at $40^{\circ} \mathrm{C}$ for 5 minutes followed by two washes in $0.1 \times$ SSC at $60^{\circ}$ for 5 minutes. The biotin-labeled DNA probes were detected by an immunoperoxidase precipitation reaction. The slides were incubated for 30 minutes at room temperature with mouseantibiotin monoclonal antibody, followed by biotinylated horse-anti-mouse lgG, and finally with avidin-biotin-peroxidase complex (all reagents from Vector Laboratories, Burlingame, CA, USA). Finally diaminobenzidine (DAB, Sigma, St Louis, MO, USA) in PBS containing $0.03 \% \mathrm{H}_{2} \mathrm{O}_{2}$ was applied for visualisation of the peroxidase activity. To improve identification of overlapping nuclei, a novel method using fluorescent DNA counterstaining with 4,6-diamino-phenylindol (DAPI, Sigma, St.Louis, MO, USA) and brightfield ISH was used. Microscopy was performed using a Leica-DMBRE microscope (Leica Mikroskopie \& Systeme GmbH, Wetzlar, Germany) equipped with a filterset for DAPI.

\section{Evaluation of In Situ Hybridization}

The number of ISH signals per nucleus was counted in at least 200 non-overlapping nuclei, following the criteria proposed by Hopman et al. ${ }^{25}$ Monosomy was defined as $>25 \%$ of nuclei with no or one signal per nucleus. Trisomy/ polysomy is defined as $25 \%$ of nuclei containing three or more signals. In accordance with other studies, $20 \%$ of aberrant nuclei was used as cut-off for a high-frequent aberration. ${ }^{2.7}$ The ISH results were categorized as 'normal' ( $<5 \%$ aberrant nuclei), 'low-aberrant' (5-20\% aberrant nuclei), and 'high-aberrant' ( $>20 \%$ aberrant nuclei). The prognostic value of these numerical chromosome aberrations was analyzed using log-rank tests on Kaplan-Meier curves.

\section{Results}

Histological revision of the forty-seven cases of A II revealed 44 (93\%) cases of fibrillary astrocytoma and three (7\%) cases of gemistocytic astrocytomas (all WHO grade II). Two 


\begin{tabular}{|l|l|l|l|}
\hline Category & Chromosome 1 & Chromosome 7 & Chromosome 10 \\
\hline Normal & $23(48 \%)$ & $17(35 \%)$ & $22(46 \%)$ \\
Low-aberrant & $22(46 \%)$ & $9(19 \%)$ & $16(33 \%)$ \\
High-aberrant & $3(6 \%)$ & $22(46 \%)$ & $10(21 \%)$ \\
\hline
\end{tabular}

TABLE 2. Summary of ISH Results in 47 cases of astrocytoma grade II.

The number (percentage) of cases with numerical chromosomal aberrations are listed according to the following categories:

Normal $=<5 \%$ of cells per case with chromosomal aberrations

Low-aberrant $=5.20 \%$ of cells per case with chromosomal aberrations

High -aberrant $=>20 \%$ of cells per case with chromosomal aberrations

of the A II samples showed a oligodendroglial component, which was however less than $20 \%$ of the nuclei. Forty-five cases were primary tumors, and two were recurrences from A II.

No patients had been subjected to prior radiotherapy. Twenty-nine (62\%) patients had undergone a stereotactic biopsy, and in 18 (38\%) patients the samples had been obtained by surgical resection. The follow-up period varied between 24 and 200 months. The median survival interval was 90 months (95\%-CI: $72 \cdot 108$ months).

Using probes for the chromosomes 1, 7 and 1 the samples with reactive gliosis showed no or only sporadic cells with three ISH signals, and were all classified as normal for all three chromosomes (Figure 1A). Of the astrocytomas grade II, 31 cases (66\%) revealed aberrations for one or more of the chromosomes investigated (Table 2). The frequency of cells exhibiting numerical chromosomal aberrations exceeded $5 \%$ in $52 \%$ of the cases for chromosome 1, in $65 \%$ of the cases for chromosome 7 (Figure 1B), and in 54\% of the cases of chromosome 10. High frequent aberrations with increased copy numbers were most frequently detected for chromosome 7. In $46 \%$ of the samples the frequency of cells with aberrations exceeded $20 \%$. A much more limited number of cases falling into the "high-aberrant" category were detected with probes for chromosomes 1 and 10 (Table 2). The most frequently detected numerical aberrations of chromosome 7 consisted of trisomies (28 cases), but a few cases showed higher copy numbers ( 3 cases). All numerical aberrations of chromosomes 1 or 10 comprised increases in copy numbers, except for two cases with monosomy 10.

In figure 2 the individual cases and the correlation between the percentages of aberrant nuclei for chromosomes 7 and 1 (Figure 2A) and chromosomes 7 and 10 (Figure $2 B$ ) have been depicted. As seen virtually all cases with aberrations of chromosomes 1 

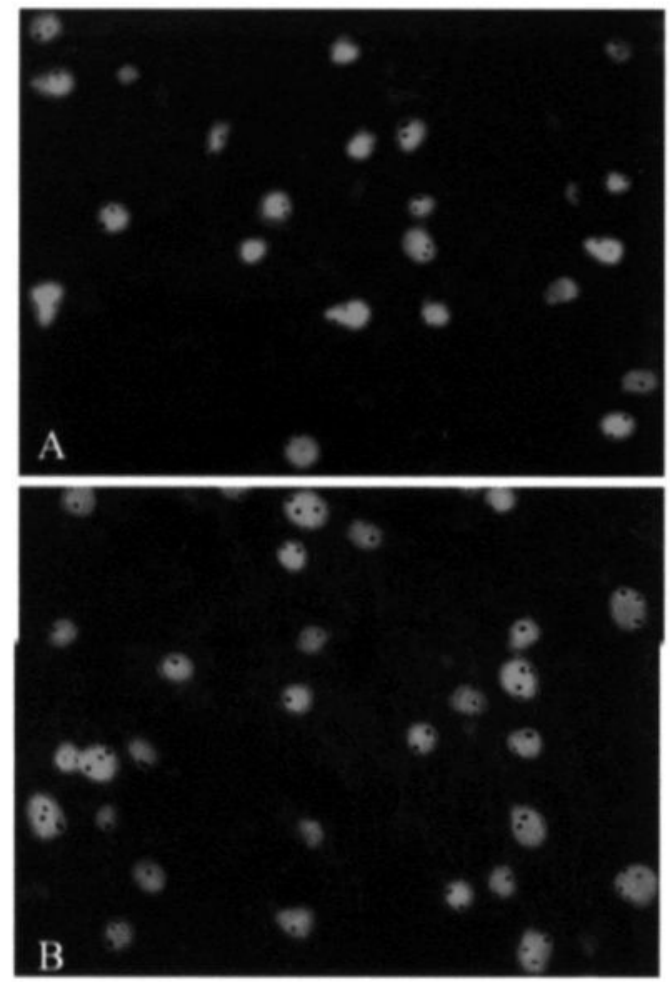

FIGURE 1. Brightfield microscopy of ISH for chromosome 7, with DAPI nuclear counterstaining. (A) A sample of reactive gliosis with no aberrations for chromosome 7. (B) Astrocytoma grade II showing frequent nuclei with three signals for chromosome 7. Magnification: $(A B) \times 800$. 


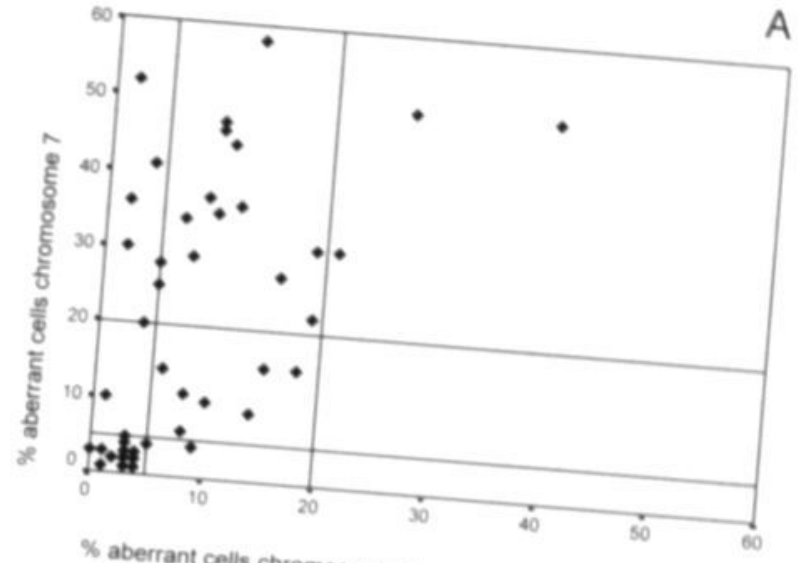

aberrant cells chromosome 1

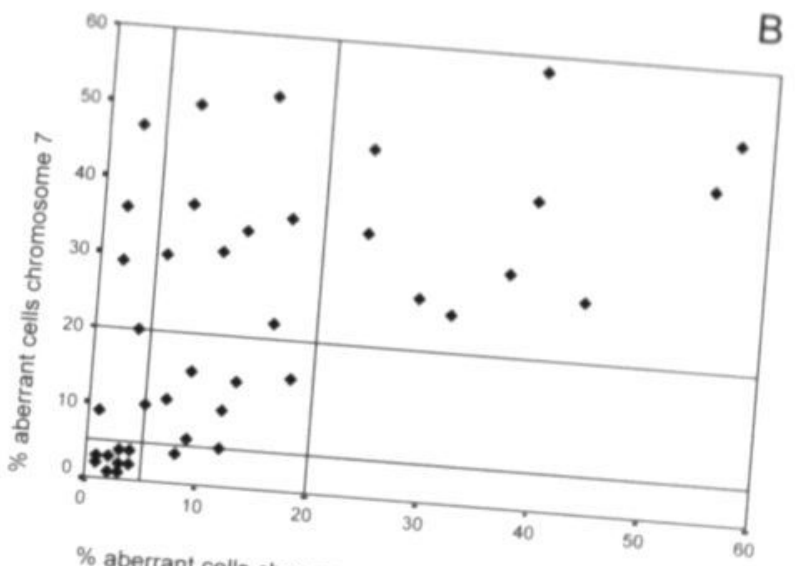

\% aberrant cells chromosome 10

FIGURE 2. Scatter plot showing the per

versus chromosome 7 (A), and for chromosome of aberrant nuclei for chromosome 7 the individual cases of astrocytoma grade 11 , 7 versus chromosome 10 chromosome 7 


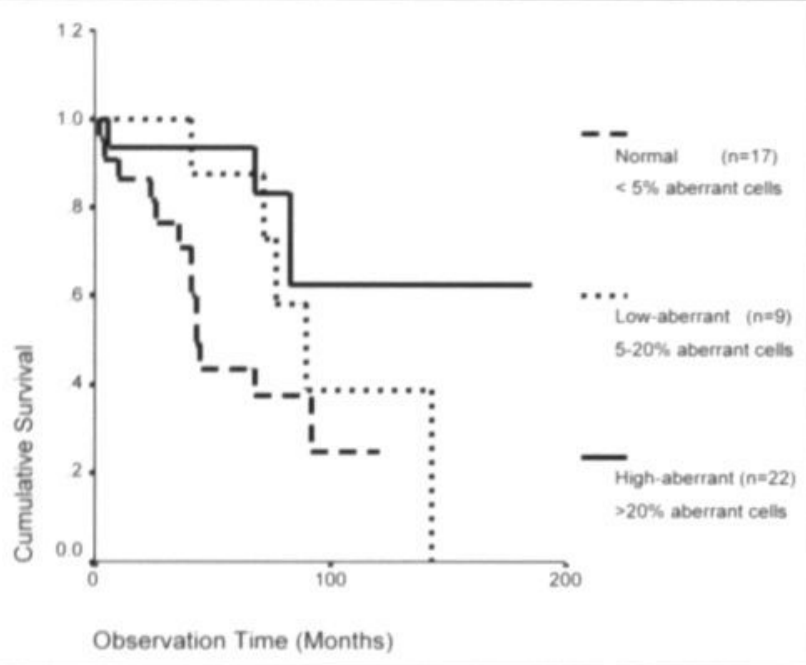

Figure 3. Survival of patients with astrocytoma grade 2 classified on the basis of aberrations of chromosome 7. High percentages (>20\%) of aberrant nuclei for chromosome 7 correlate most strongly with shorter survival (log-rank: p-value 0.028 ).

and/or 10 also exhibit (high) frequencies of cells with aberrations of chromosome 7. The reverse, i.e. cases with aberrations for chromosome 7 also showing chromosome 1 and 10 deviations, only holds true for a limited number of cases.

The results of the Kaplan Meier analyses are shown in Figure 3. Trisomy/polysomy 7, according to the different categories, correlates with shorter survival (log-rank; $p=0.028$ ). High-frequent aberrations of chromosome 7 (>20\% of trisomic/polysomic cells as cut-off; high-aberrant group) correlated strongly with shorter survival as compared to A II with disomy or a low frequency of aberrations for chromosome 7 (normal and low-aberrant group taken together; log-rank; $p=0.008$; not shown in Figure 3 ). The two tumors with monosomy 10 showed extremely short survival intervals, i.e. 10 and 24 months.

\section{Discussion}

The present study shows that numerical aberrations of chromosome 7 are frequently occurring in astrocytoma grade II (A II) and that their detection by in situ hybridization (ISH) are of prognostic value. The absence or extremely low frequency of numerical 
chromosome 7 aberrations in the control samples with non-neoplastic reactive gliosis is in accordance with the results of eartier ISH studies in non-neoplastic brain tissue. ${ }^{17,}$ is This may suggest that trisomy 7 , as detected by classical banding analysis in normal and gliotic brain tissue, most probably is due to culturing artifacts. ${ }^{15}$. 16 Another possible explanation is that the normal brain tissues in the study of Heim et al ${ }^{15}$ contained malignant cells, because seven of their 11 patients were reported to have malignant brain tumors. However, due to limitations of the ISH technique, we cannot rule out the presence of small clones of cells with trisomy 7 in our gliotic samples.

Our ISH findings in A II corroborate with results of previous, smaller series (Table 1). Trisomy 7 was described by Perry et al ${ }^{2}$ in half of the A II cases examined. In a doublelabel ISH experiment, Steilen-Gimbel et al ${ }^{10}$ showed gains of both chromosomes 7 and 10. CGH studies also suggest that gain or amplification of in particular chromosomes 7 and/ of $8 \mathrm{q}$ is typical for A II (Table 1). In this study we show that high-frequent trisomy/polysomy of chromosome 7 is strongly correlated with shorter survival, suggesting a clonal expansion of this cell population during the malignant progression of A II.

Polysomy, in particular trisomy, of chromosome 7 is not only frequently detected in A II but is also seen in other preneoplastic and neoplastic lesions. Trisomy 7 was already shown to correlate with poor prognosis in prostate carcinoma. ${ }^{26}$ Furthermore, this aberration is present in the stemcell compartment of colon carcinoma and has been suggested to be involved in the transition of colon adenoma to carcinoma. ${ }^{27}$ Thyreoid hyperplasia with trisomy 7 is supposed to progress more often to adenoma and carcinoma. ${ }^{28}$

These studies and our present findings strongly support the involvement of trisomy/polysomy 7 in carcinogenesis and tumor progression. We found no strong indications that trisomy/polysomy 7 is associated with reactive gliosis, and therefore can not support the suggestion that this represents a preneoplastic process. ${ }^{16}$ Furthermore, the presence of trisomy/polysomy 7 did not correlate with the age of the patients in the series of A II described here (unpublished), as was suggested for several other types of solid tumors by Broberg et al. ${ }^{29}$

We conclude that astrocytoma grade II frequently contains a considerable number of tumor cells with trisomy/polysomy 7. The detection of this numerical chromosomal aberration by ISH may thus be of prognostic value in this type of brain tumor. 


\section{References}

1. Kraus JA, Bolln C, Wolf HK, Neumann J, Kindermann D, Fimmers R, Forster F, Baumann A, Schlegel U. TP53 aiterations and clinical outcome in low grade astrocytomas. Genes Chromosomes Cancer 1994; 10: 143-149.

2. Perry A, Tonk V, McIntire DD, White CL. Interphase cytogenetic (in situ hybridization) analysis of astrocytomas using archival, formalin-fixed, paraffin-embedded tissue and nonfluorescent light microscopy. Am J Clin Pathol 1997; 108: 166-174.

3. Saltinen SL, Sallinen P, Haapasalo $\mathrm{H}$, Kononen J, Karhu R, Helen P, Isola J. Accumulation of genetic changes is associated with poor prognosis in grade II astrocytomas. Am J Pathol 1997; 151: 1799-1807.

4. Kimmel DW, OFallon JR, Scheithauer BW, Kelly PJ, Dewald GW, Jenkins RB. Prognostic value of cytogenetic analysis in human cerebral astrocytomas. Ann Neurol 1992; 31: 534 . 542.

5. von Deimling A, Eibl RH, Ohgaki H, Louis DN, von Ammon K, Petersen I, Kleihues P, Chung RY, Wiestler $O D$, Seizinger BR. p53 mutations are associated with 17p allelic loss in grade II and grade III astrocytoma. Cancer Res 1992; 52: 2987-2990.

6. Rey JA, Bello MJ, de Campos JM, Kusak ME, Moreno S. Chromosomal composition of a series of 22 human low-grade gliomas. Cancer Genet Cytogenet 1987; 29: 223-237.

7. Campomenosi P, Ottaggio L, Moro F, Urbini S, Bogliolo M, Zunino A, Camoriano A, Inga A, Gentile SL, Pellegata NS, Bonassi S, Bruzzone E, lannone R, Pisani R, Menichini P, Ranzani GN, Bonatti S, Abbondandolo A, Fronza G. Study on aneuploidy and p53 mutations in astrocytomas. Cancer Genet Cytogenet; 88: 95-102.

8. Liu N, Numa Y, Kasai H, Tsuchida T, Kawamoto K. Analysis of sex chromosomal numerical aberrations in human astrocytomas by FISH. Int J Oncol 1997; 10: 497-502.

9. Rosso SM, van Dekken H, Krishnadath KK, Alers JC, Kros JM. Detection of chromosomal changes by interphase cytogenetics in biopsies of recurrent astrocytomas and oligodendrogliomas. J Neuropathol Exp Neurol 1997; 56: 1125-1131.

10. Steilen-Gimbel H, Henn W, Kolles H, Moringlane JR, Feiden W, Steudel WI, Zang KD. Early proliferation enhancement by monosomy 10 and intratumor heterogeneity in malignant human gliomas as revealed by smear preparations from biopsies. Genes Chromosomes Cancer 1996; 16: 180-184.

11. Wernicke C, Thiel G, Lozanova T, Vogel S, Witkowski R. Numerical aberrations of chromosomes 1, 2, and 7 in astrocytomas studied by interphase cytogenetics. Genes Chromosomes Cancer 1997: 19: 6-13.

12. Nishizaki T, Ozaki S, Harada K, Ito H, Arai H, Beppu T, Sasaki K. Investigation of genetic alterations associated with the grade of astrocytic tumor by comparative genomic hybridization. Genes Chromosomes Cancer 1998; 21: 340-346.

13. Schrock E, Thiel G, Lozanova T, du Manoir S, Meffert MC, Jauch A, Speicher MR, Nurnberg P, Vogel S, Janisch W, et al. Comparative genomic hybridization of human malignant 
gliomas reveals multiple amplification sites and nonrandom chromosomal gains and losses. Am J Pathol 1994; 144: 1203-1218.

14. Weber RG, Sabel M, Reifenberger J, Sommer C, Oberstrass J, Reifenberger G, Kiessling M, Cremer T. 1996. Characterization of genomic alterations associated with glioma progression by comparative genomic hybridization. Oncogene 1996; 13: 983-994.

15. Heim S, Mandahl N, Jin Y, Stromblad S, Lindstrom E, Salford LG, Mitelman F. Trisomy 7 and sex chromosome loss in human brain tissue. Cytogenet Cell Genet 1989; 52: 136-138.

16. Moertel CA, Dahl RJ, Stalboerger PG, Kimmel DW, Scheithauer BW, Jenkins RB. Gtiosis specimens contain clonal cytogenetic abnormalities. Cancer Genet Cytogenet 1993; 67: 21.27.

17. Arnoldus EP, Noordermeer IA, Peters AC, Raap AK, Van der Ploeg M. Interphase cytogenetics reveals somatic pairing of chromosome 17 centromeres in normal human brain tissue, but no trisomy 7 or sex- chromosome loss. Cytogenet Cell Genet 1991; 56: 214-216.

18. Datrymple SJ, Herath JF, Borell TJ, Moertel CA, Jenkins RB. Correlation of cytogenetic and fluorescence in situ hybridization (FISH) studies in normal and gliotic brain. J Neuropathol Exp Neurol 1994; 53: 448-456.

19. Kleihues P, Burger PC, Scheithauer BW. 1993. Histological typing of tumors of the central nervous system, 2nd Ed. Geneva: World Health Organization.

20. Wessels PH, Hopman AHN, Ummelen MIJ, Krijne-Kubat B, Ramaekers FCS, Twijnstra A. Differentiation between reactive gliosis and diffuse astrocytoma by in situ hybridization. Neurology 2001; 56: 1224-1227.

21. Hopman AHN, Poddighe P, Moesker O, Ramaekers FCS. 1992. Interphase cytogenetics: an approach to the detection of genetic aberrations in tumours. In Herrington CS, McGee JO'D, editors. Diagnostic molecular pathology. Oxford, IRL. Press. p 141-161.

22. Cooke HJ, Hindley J. Cloning of human satellite III DNA: different components are on different chromosomes. Nucleic Acid Res 1979; 6: 3177-3197.

23. Waye JS, England SB, Willard HF. Genomic organisation of alpha satellite DNA on human chromosome 7: evidence for two distinct alphoid domains on a single chromosome. Mol Cell Biol 1987; 7: 349-356.

24. Devilee P, Kievits T, Waye JS, Pearson PL, Willard HF. Chromosome -specific alpha satellite DNA: isolation of a polymorphic alphoid repeat from human chromosome 10. Genomics 1988; 3: 1-7.

25. Hopman AHN, Ramaekers FCS. 1998. Processing and staining of cell and tissue material for interphase cytogenetics. In Robinson JP, editor. Current protocols in cytometry. New York, John Wiley \& Sons, Inc. Chapter 8.5.1-8.5.2

26. Bandyk MG, Zhao L, Troncoso P, Pisters LL, Paimer JL, von Eschenbach AC, Chung LW, Liang JC. Trisomy 7: a potential cytogenetic marker of human prostate cancer progression. Genes Chromosomes Cancer 1994; 9: $19 \cdot 27$. 
27. Herbergs J, Arends JW, Bongers EM, Ramaekers FCS, Hopman AHN. Clonal origin of trisomy for chromosome 7 in the epithelial compartment of colon neoplasia. Genes Chromosomes Cancer 1996; 16: 106-112.

28. Belge G, Thode B, Rippe V, Bartnitzke S, Bullerdiek J. A characteristic sequence of trisomies starting with trisomy 7 in benign thyroid tumors. Hum Genet 1994; 94: 198-202.

29. Broberg K, Toksvig-Larsen S, Lindstrand A, Mertens F. Trisomy 7 accumulates with age in solid tumors and non-neoplastic synovia. Genes Chromosomes Cancer 2001; 30: 310-315. 


\section{5}

\section{Proliferation and aneusomy}

\section{strongly predict survival of young \\ patients with astrocytoma grade}

II.

Presented at the $54^{\text {th }}$ Annual Meeting of the American Academy of Neurology, April 15th 2002, Denver, US

Wessels PH, Hopman AHN, Krijne-Kubat B, Kessels AGH, Hoving EW, Ummelen MIJ, Ramaekers FCS, Twijnstra A. Br J Cancer 2003; 89: 128-34. 


\begin{abstract}
The clinical course of astrocytoma grade II (AII) is highly variable and not reflected by histological characteristics. As one of the best prognostic factors higher age identifies rapid progressive A II. For patients over 35 years of age an aggressive treatment is normally advised. For patients under 35 years there is no clear guidance for treatment choices, and therefore also the necessity of histopathological diagnosis is often questioned. We studied the additional prognostic value of the proliferation index and the detection of genetic aberrations for patients with A II. The tumour samples were obtained by stereotactic biopsy or tumour resection and divided into two age groups, i.e. 18-34 year $(n=19)$ and $\geq 35$ year $(n=28)$. Factors tested included the proliferation (Ki-67) index, and numerical aberrations for chromosomes 1, 7 and 10, as detected by in situ hybridization (ISH). The results show that age is a prognostic indicator when studied in the total patient group, with patients above 35 years showing a relatively poor prognosis. Increased proliferation index in the presence of aneusomy appears to identify a subgroup of patients with poor prognosis more accurately than predicted by proliferation index alone. We conclude that histologically classified cases of A II comprise a heterogeneous group of tumours with different biological and genetic constitution, that exhibit a highly variable clinical course. Immunostaining for $\mathrm{Ki}-67$ in combination with the detection of aneusomy by ISH allows the identification of a subgroup of patients with rapidly progressive A II. This is an argument not to defer stereotactic biopsy in young patients with radiological suspicion of A II.
\end{abstract}




\section{Introduction}

Controversy exists with respect to optimal treatment protocols for low-grade diffuse astrocytoma (astrocytoma WHO grade II; A II) because prospective studies comparing treatment strategies are rare. ${ }^{1 \cdot 3}$ Another reason for this controversy is that the interval after which malignant progression of A II occurs is difficult to predict. Clinical factors that may correlate with survival include those related to patient age, presenting symptoms, duration of symptoms, performance status, tumour volume, extent of resection, and timing and dose of radiotherapy. 4,5 Patient age is the single consistent prognostic factor in these retrospective studies. Patient age under 35 years, ${ }^{6,7}$ or under 40 years in other series ${ }^{8}$ is often associated with a prolonged survival. Because the benefits of early treatment have to be balanced against the possibility of long-term side effects from radiation therapy, patient age is decisive in current treatment protocols for A II. For patients under 35 years of age the benefit of early and aggressive treatment has never been proven sufficiently and therefore treatment is often deferred.' As a result in young patients also a controversy exists concerning the usefulness of an immediate histological diagnosis, involving stereotactic biopsy. ${ }^{10}$

Ultimately the majority of A II progresses to high-grade astrocytomas (astrocytoma WHO grade III and grade IV; A III/A IV), which is characterized by an increase in proliferation activity and an accumulation of genetic abnormalities. Proliferation and cytogenetic markers may therefore identify rapid progressive A II. Increased proliferation activity correlates with shorter survival in most series of astrocytomas, although the number of A II was often too small for separate analyses. ${ }^{11,12}$ Numerical chromosomal aberrations have been reported in astrocytomas, such as aneusomy 1 , trisomy 7 and monosomy 10. It has been shown that trisomy 7 correlates with shorter survival of A II patients. ${ }^{13}$

In the underlying study the prognostic value of the proliferation (Ki-67) index and the detection of numerical aberrations for the chromosomes 1, 7 and 10 was evaluated. The correlation of these parameters with survival analysis was performed for patients aged 18-34 years and 235 years to assess whether these parameters allow the identification of rapid progressive A II in young patients. 


\section{Material and methods}

\section{Patient material}

Tissue specimens from 47 adult patients diagnosed with supratentorial astrocytoma grade II (A II) were collected from the data files of the departments of Pathology of the University Hospitals of Maastricht and Groningen, and the Atrium Hospital in Heerlen, The Netherlands. Histopathological revision according to the WHO classification ${ }^{14}$ revealed $\mathbf{4 4}$ fibrillary astrocytomas and three gemistocytic astrocytomas (all WHO grade II). Astrocytomas with mitotic figures were not included in this series. In order to diminish the probability of sampling error A II in which the neuro-radiologists suspected high-grade astrocytoma and which showed radiological characteristics for tumor bleeding as well as extensive contrast enhancement, were not included in this series. Patient records were examined with regard to the first neurological symptoms, radiological findings, neurosurgical procedure, dose and timing of radiotherapy, and survival interval.

Mean and median age was respectively 38 and 41 years (range: 18 to 69 years). The study included 22 women $(47 \%)$ and 25 men (53\%). Seizures were the most frequent presenting symptom (77\%), followed by focal neurological deficit (26\%), mental changes (15\%) and signs of raised intra-cranial pressure (17\%). The median duration of pre. operative symptoms was 3 months (range: 1 week to 157 months). Most tumours were located in the frontal (51\%) and temporal/parietal (45\%) lobes and less frequently in the occipital lobe (4\%). The majority of patients $(n=41)$ underwent neurosurgery immediately after coming to medical attention and had their first neuro-imaging test. In six patients neurosurgical intervention was extended for 36 to 150 months. No association was found, using Pearson's correlation coefficient, between pre-operative interval and proliferation index or chromosomal status. For this reason all cases were included in this study.

Neurosurgical procedures consisted of a biopsy in $29(62 \%)$ and resection in 18 (38\%) patients. Radiotherapy was given immediately post-operative in $28(60 \%)$ patients, delayed in $10(21 \%)$ patients, and nine (19\%) patients were still not irradiated at the last follow-up.

\section{Proliferation index: Ki-67 immunohistochemistry}

Five micron thick paraffin sections were pre-incubated in methanol with $0.3 \% \mathrm{H}_{2} \mathrm{O}_{2}$. Tissues known to be negative and positive for $\mathrm{Ki}-67$ were used as controls. Antigen retrieval was achieved by incubation with $10 \mathrm{mM}$ citrate buffer $(\mathrm{pH} 6.0)$ in a domestic 
microwave oven at $700 \mathrm{~W}$ for ten minutes. The sections were incubated with the mouse monoclonal antibody MIB-1 directed against Ki-67 (Immunotech S.A. Marseille, France) at a 1:12 solution in PBS containing $4 \%$ normal goat serum for 60 minutes. Subsequently, biotin-labelled horse anti-mouse antibody at a 1:200 dilution and avidinbiotin peroxidase complex (Vector Laboratories, Burlingame, CA, US) were applied for 60 and 45 minutes, respectively. Peroxidase activity was detected using diaminobenzidine in PBS/ imidazol buffer with $0.02 \% \mathrm{H}_{2} \mathrm{O}_{2}$. Nuclei were scored for positivity in 500 cells in each sample in the areas with highest immunopositivity. The mean proliferation (Ki-67) index was $2.7 \%$ (range 0.0\%-9.2\%).

\section{In situ hybridization}

In situ hybridization (ISH) was performed as described earlier. ${ }^{15}$ Five-micron thick paraffin sections were deparaffinized and pre-treated in $85 \%$ formic acid/ $0.3 \% \mathrm{H}_{2} \mathrm{O}_{2}$ for 20 minutes. Thereafter the slides were incubated in $1 \mathrm{M}$ sodium-thiocyanate at $80^{\circ} \mathrm{C}$ for 10 minutes. Subsequently proteolytic digestion was performed by $4 \mathrm{mg} / \mathrm{ml}$ pepsin (Sigma Chemical Co, St.Louis, MO) for 10 minutes at $37^{\circ} \mathrm{C}$ in $0.02 \mathrm{M} \mathrm{HCl}$. Then the slides were fixed in $1 \%$ formaldehyde in phosphate buffered saline (PBS) for 15 minutes, and rinsed in PBS and double distilled water.

The biotin-labeled DNA probes used in this study were specific for the centromeric region of chromosome 1 (1q12, pUC 1.77), the alphoid region of chromosome 7 (p7t1) and the pericentromeric region of chromosome 10 (D10Z1). The probes were hybridised to the target-DNA in a mixture containing $2 \times$ standard saline citrate (SSC), 60\% formamide, $10 \%$ dextran sulphate, and $0.2 \mathrm{mg} / \mathrm{ml}$ herring sperm DNA. After denaturation at $80^{\circ} \mathrm{C}$ for 5 minutes the slides were incubated overnight at $37^{\circ} \mathrm{C}$. Subsequently, the slides were washed twice in $2 \times \mathrm{SSC} / 0.05 \%$ Tween at $45^{\circ} \mathrm{C}$, and in 4 $\mathrm{X} \mathrm{SSC/} 0.05 \%$ Tween at room temperature. To detect probe hybridization the slides were incubated for 30 minutes at room temperature with mouse-antibiotin monoclonal antibody, followed by biotinylated horse-anti-mouse, and finally with the avidin-biotinperoxidase complex (Vector Laboratories, Burlingame, CA). Finally $0.1 \mathrm{M}$ diaminobenzidine (Sigma) in PBS containing 0.03\% H2O2 was applied for visualisation of the peroxides activity. To improve identification of the individual nuclei bright-field microscopy was combined with fluorescent nuclear counterstaining using 4,6-diaminophenylindol (DAPI, Sigma). The samples were evaluated with a Leica DMBRE microscope (Leica Mikroskopie \& Systeme $\mathrm{GmbH}$, Wetzlar, Germany). The number of signals per nucleus was counted in at least 200 non-overlapping nuclei. Trisomy/ polysomy (gain) was defined as $>5 \%$ of nuclei containing three or more signals, and monosomy (loss) as $>25 \%$ of nuclei with none or one signal per nucleus. The tumours were classified as 
aneusomic when gain or loss of at least one of the chromosomes was detected The other A II were classified as disomic. As detected by in situ hybridization 32 (68\%) of the tumours showed aneusomy for one or more of the chromosomes investigated. The most frequent aberration was aneusomy for chromosome 7 in 31 (66\%) of A II. Aneusomy for chromosome 1 was detected in 24 (51\%) and aneusomy for chromosome 10 in 25 (53\%) of the samples. Monosomy 10 was only detected in two samples (4\%), which both also showed trisomy/polysomy 7. The data of the individual chromosomes are described in detail elsewhere. ${ }^{13}$

\section{Statistical analyses}

The following factors were considered as possible prognostic parameters for survival: patient age, sex, presenting symptoms, pre-operative duration of symptoms, tumour location, neuro-surgical procedure, timing of radiotherapy, proliferation index and chromosomal status.

The influence of these factors on survival was tested by univariate analysis using log. rank tests. Possible prognostic factors from the univariate analyses with p-values less than 0.10 (according to recommendation in the literature ${ }^{16}$ were entered into the multivariate analyses using a forward stepwise method in order to identify independent prognostic parameters. ${ }^{17}$ Univariate and multivariate associations between factors and survival were assessed with a Cox regression model. Subsequently tumour-related factors were used for analysis in age-stratified groups.

\section{Results}

The median survival interval for patients with astrocytoma grade II as estimated by the Kaplan- Meier method was 90 months (95\% confidence interval 72 to 108 months). When determining the influence of age on the period of survival after the first diagnosis of $A$ II it becomes obvious that the group aged 235 years at the time of diagnosis exhibits a significantly shorter survival period as compared to the 18-34-aged patient group (Figure 1; Log-rank; p-value=0.05). Other factors significantly associated with shorter survival were focal neurological deficit at presentation, proliferation (Ki-67) index >1\%, and aneusomy. 
Figure 1. Association between patient age (18-34 vs. 235 years) and survival in A II. (Kaplan-Meier, log-rank test, p-value $=0.05$ )

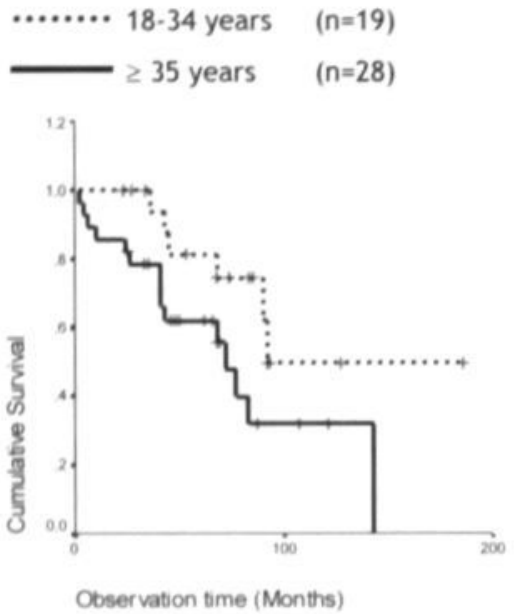

FIGURE 2 High proliferation (Ki.67) index in A II is associated with shorter survival in (A) patients aged 18 -34 ( $p$-value $=0.02)$ and $(B)$ patients $\geq 35$ years $(p$-value $=0.03$ ).

(Kaplan-Meier; pooled log-rank test, p-value $=0.002$ )

\section{Proliferation index $\leq 1 \%(\mathrm{n}=18)$}

Proliferation index $>1 \%(n=29)$

A

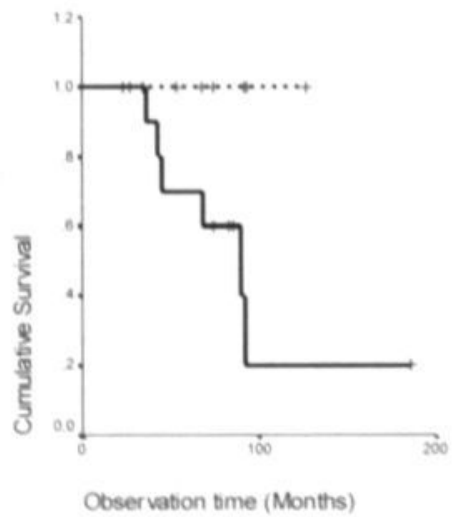

B

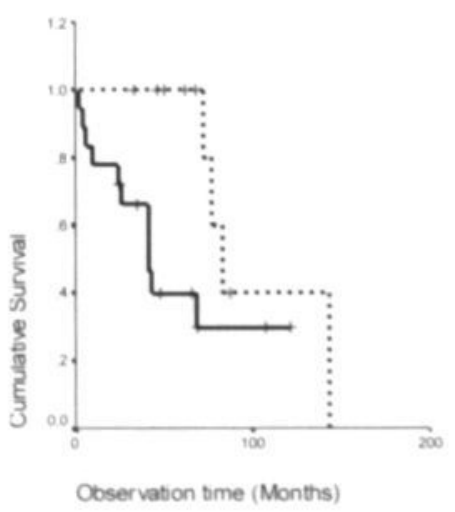




\section{FIGURE 3}

Relation of aneusomy with shorter survival in (A) A II patients aged 18.34 (p-value=0.36) and (B) patients 235 years ( $\mathrm{p}$-value $=0.09$ ). (Kaplan-Meier; pooled log-rank test, $p=0.05$ )

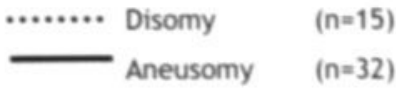

A

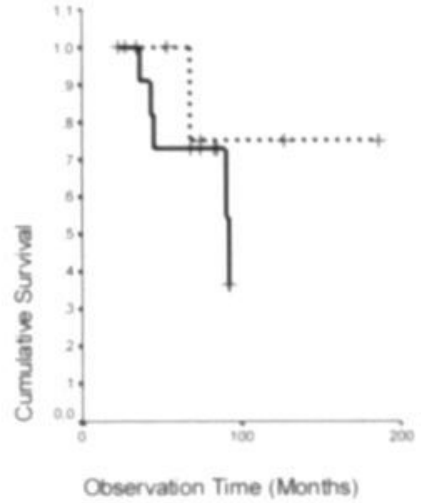

B

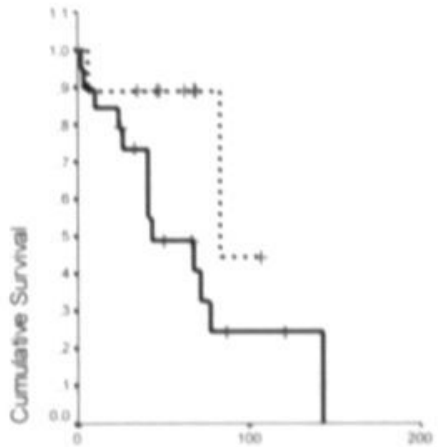

Observaton Time (Months)

FIGURE 4

The combination of both high proliferation ( $\mathrm{Ki}-67$ ) index and aneusomy is strongly associated with a shorter survival in A II patients (A) aged 18-34 $(p=0.01)$ and $(B)$ aged 235 years $(p=0.001)$. (Kaplan-Meier; pooled log-rank test, $\mathrm{p}<0.0001$ )

Proliferation index $\leq 1 \%$ or Disomy $\quad(n=26)$

Proliferation index $>1 \%$ and Aneusomy $(n=21)$

A

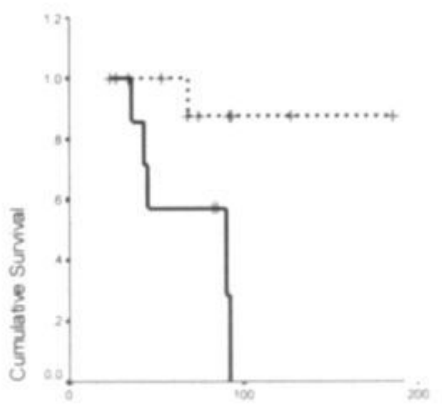

Ooservaton time (months
B

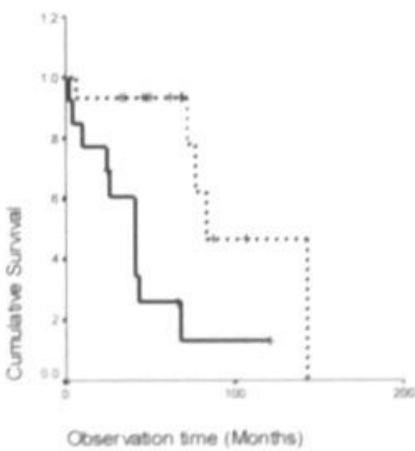


Univariate analysis

\begin{tabular}{|ll|ll|l|}
\hline & & \multicolumn{2}{l|}{} & \\
PARAMETER & & \multicolumn{2}{l|}{ HAZARD RATIO $(95 \% \mathrm{CI})^{\circ}$} & P-VALUE \\
\hline Proliferation index $>1 \%$ & $(n=29)$ & 3.63 & $(1.22-10.82)$ & 0.02 \\
Focal neurological deficit & $(n=13)$ & 2.78 & $(1.12-6.90)$ & 0.03 \\
Aneusomy & $(n=32)$ & 3.29 & $(0.97-11.20)$ & 0.06 \\
Patient age $>35$ years & $(n=28)$ & 2.52 & $(0.97-6.58)$ & 0.06 \\
\hline
\end{tabular}

Multivariate analysis

\begin{tabular}{|ll|ll|l|}
\hline & & \multicolumn{2}{|l|}{} & \\
PARAMETER & & \multicolumn{2}{|l|}{ HAZARD RATIO $(95 \% \mathrm{CI})$} & P.VALUE \\
\hline Proliferation index $>1 \%$ & $(n=29)$ & 4.81 & $(1.50-15.38)$ & 0.01 \\
Patient age $\geq 35$ years & $(n=28)$ & 3.01 & $(1.13-7.99)$ & 0.03 \\
Aneusomy & $(n=32)$ & $3.66 \quad(1.06-12.62)$ & 0.04 \\
\hline
\end{tabular}

TABLE 1. Unfavourable prognostic factors for patients with astrocytoma grade II.

Upon multivariate analysis proliferation index $>1 \%$, patient age $\geq 35$ years, and aneusomy were independently correlated with shorter survival (Table 1). To investigate the interactions between the proliferation index and aneusomy with age we analysed the influence of these two factors on survival stratified for age. When correlating the proliferation index to survival in the two age groups separately, it appears that in the group of 18-34 year old patients a clear-cut distinction can be made between those with a proliferation index $\leq 1 \%$, showing long-term survival, and those with a proliferation index $>1 \%$, showing more progressive A II (Figure 2A; Log-rank; p-value $=0.02$ ). Also in the 235 year old patients the proliferation index proved to have additional prognostic value, although less apparent as compared to the younger group (Figure 2B; p-value $=0.03$ ).

Using the in situ hybridization protocol with probes for chromosomes 1,7 and 10, cases of A II with an apparently normal (disomic) chromosomal content can be separated from aneusomic cases. In the whole group of patients with A II the detection of aneusomy has additional value in distinguishing between rapid and slow progressive $A$ II. In the stratified age groups an aberrant chromosomal constitution is not associated with shorter survival in both the 18.34 year (Figure $3 A$; p-value $=0.36$ ) and the 235 year (Figure 38; p-value=0.09) old group.

However, the combination of a high proliferation index and aneusomy very accurately identified patients with an unfavourable outcome in both the 18-34 year (Figure 4A; pvalue $=0.01$ ) and the $z 35$ year-old patient groups (Figure $4 B$; $p$-value $=0.001$ ). The 
combination of both factors reclassified three (27\%) of 11 patients of $18-34$ years into the group with relative good prognosis (Compare Figure 4A to $2 \mathrm{~A}$ ). In five of 18 patients in the 235 years group the high proliferation index with disomy now correlated with a more favourable course (compare Figure 48 to Figure 28 ).

Figure 5 illustrates a case of A II, localised in the frontal lobe of a 25 -year patient with epileptic seizures as sole manifestation. The proliferation (Ki-67) index was $4.5 \%$ and a high-percentage (35\%) of nuclei with trisomy for chromosome 7 was detected by ISH. Despite the favourable clinical features (young age, no focal deficit) the patient rapidly progressed to astrocytoma grade IV, and the survival interval after histological diagnosis was only 36 months.

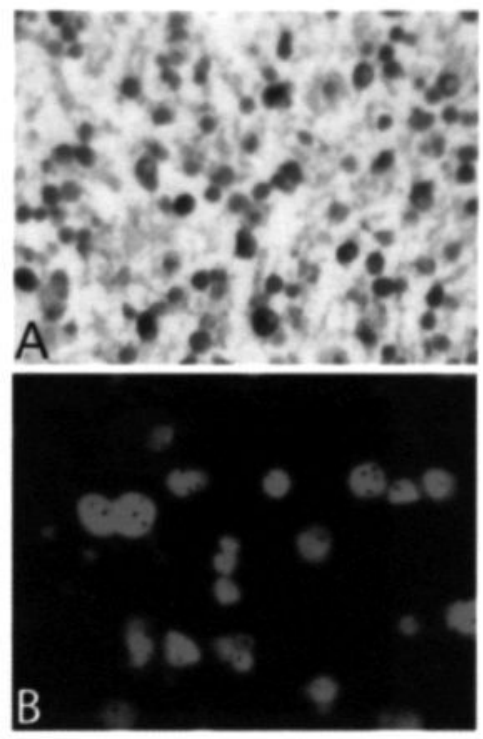

FIGURE 5. Astocytoma grade II in a patient aged 25 years with high proliferation (Ki-67) index (A), and frequent nuclei with trisomy for chromosome 7 , detected by in situ hybridization (B).

Counter-staining with DAPI in B. Magnifications $\times 800$ 


\section{Discussion}

A 'wait and see' policy has been propagated for patients under 35 years of age, suffering from epileptic seizures and radiological suspicion of astrocytoma grade II (A II). ${ }^{9}$ An important argument for not performing a stereotactic biopsy in these patients is that the histological diagnosis of A II does not alter treatment strategy. In the current study we demonstrate that the detection of a high proliferative activity in combination with chromosomal aberrations identifies a subgroup of young A II patients with a rapid malignant course.

Our study confirms previous studies of A II showing the prognostic value of patient age and symptoms at presentation. ${ }^{5,8}$ In multivariate analyses only the age of patients at diagnosis remained significantly associated with survival as an independent clinical factor, when comparing patient groups under and over 35 years of age. However, when including biological factors describing the proliferative capacity and genomic constitution of the lesion, subgroups of patients with a significantly shorter survival could be distinguished within these two separate age groups. In our study immunostaining for the proliferation marker Ki-67 in over $1 \%$ of tumour cells showed the strongest association with survival of patients with A II. The proliferation (Ki-67) index has been described to increase with the grade of astrocytomas although overlap between grades exists. ${ }^{11,12}$ The additional value of the $\mathrm{Ki-67}$ labelling protocol in A II was also demonstrated in two recent studies, although in these studies no stratification for patient age was performed. ${ }^{18,19}$

We show a significant correlation of proliferation (Ki-67) index with survival for patients under 35 years, separating a group of young patients with a high proliferation index and a prognosis similar to that of patients $>35$ years. Immunolabeling of lesions from patients 235 years of age identified a subgroup with a low proliferation index, correlating with a somewhat better prognosis. In the multivariate analysis a proliferation (Ki-67) index $>1 \%$ proved to be a strong independent prognosticator. This corroborates with a bromodeoxyuridine-(BrdU)- proliferation marker analysis of A II that also showed cell cycle activity in $>1 \%$ of tumour cells to be associated with shorter survival. ${ }^{20} \mathrm{~A}$ possible drawback of the proliferation (Ki-67) index as prognosticator in A II is reflected by the wide variation of cut-off levels (between $2 \%$ and $10 \%$ ) used in different studies. ${ }^{18,19.21}$ In our series the discriminative power of the proliferation (Ki67) index diminished when using a higher cut-off level than 1\% (data not shown). These differences in cut-off levels, amongst different studies, may be explained by differences in the immunohistochemical procedures applied such as the method of 
antigen retrieval, the immunolabelling protocol, and by differences in the scoring criteria of (clustered) Ki-67 positive cells. Therefore, an additional, but independent prognosticator is needed.

The detection of numerical genomic aberrations has such additional prognostic value to the proliferation (Ki-67) index. For astrocytomas of all grades it appears that certain genetic changes are associated with an unfavourable clinical course. Astrocytomas with chromosomal abnormatities as detected by karyotyping cause a shorter survival as compared to astrocytomas without these abnormalities. ${ }^{22}$ An in situ hybridization study showed that monosomy for chromosome 10, harbouring the tumour suppressor gene PTEN/MUAC1, results in shorter survival. ${ }^{23}$ However, in these series the majority of tumours represented high-grade astrocytoma (grades III and IV). In A II the most frequently reported genetic aberration is loss or mutation of the p53-gene, which shows however no association with clinical course. ${ }^{24.25}$

One of the very few additional studies correlating genetic aberrations and clinical course includes a comparative genomic hybridization (CGH) analysis which showed that A II with rapid matignant progression exhibit a significantly higher number of chromosomal aberrations as compared to A II with an indolent behaviour. ${ }^{26}$ However, the sensitivity of this CGH technique is relatively low due to contamination with normal/reactive cells, which are often present in A II. ${ }^{27}$

In contrast, the in situ hybridization (ISH) procedure is a routinely applicable to paraffin embedded samples of central nervous system tumours. ${ }^{28}$ Our study demonstrates that the detection of chromosomal aberrations by ISH, using a panel of probes for chromosomes 1, 7 and 10, offers an extra independent predictor for survival of patients with A II. After stratification for age the presence of chromosomal aberrations alone is not significantly associated with shorter survival, which may be caused by the small size of both groups. However, in both age groups the detection of aneusomy by ISH adds value to the proliferation index, in that increased proliferation in the presence of chromosomal aberrations is associated with a poor prognosis.

A correlation between aneusomy and proliferative activity was demonstrated in astrocytomas of all grades, containing aneusomies for chromosome 7 and 10 particularly in Ki-67. positive cells. ${ }^{29}$ This suggests that an accumulation of chromosomal aberrations in proliferating cells plays an important role in the early stages of astrocytoma progression. This also suggests that the combination of both these parameters is therefore very useful in identifying A II with a rapidly malignant clinical course.

Although imaging studies were used as adjunct to histology, also A III/IV may present as non-enhancing lesions. ${ }^{30}$ Therefore one could argue that in the stereotactic specimen 
sampling error from high-grade astrocytomas may have biased the results. This is contradicted, however by the relatively long median survival of 90 months, also compared to other A II studies. ${ }^{31,32}$ Another argument against underscoring of the tumours is given by the fact that only one of the biopsy specimens exhibited monosomy 10 , which is characteristic for low-grade areas in high-grade astrocytomas. ${ }^{33}$

The additional value of genetic and biological parameters to the current histological WHO classification was also seen in the three gemistocytic variants of A II. Previous studies suggest that A II with high percentages ( $>60 \%)$ of gemistocytes, in fact behave more similar to A III. ${ }^{34}$ Although two of our gemistocytic samples contained lower percentages of gemistocytes, the increased proliferation activity and the presence of aneusomy in all three samples was associated with a relatively short survival (range 41 . 43 months).

We postulate that identification of subtypes of astrocytomas on basis of genetic and biological factors has additional prognostic value to the current histological classification. Tissue should be obtained in all patients with A II in order to assess the proliferation activity and, if possible, the presence of trisomy for chromosome 7 . In the future these markers may help optimising treatment strategy, in particular in young patients with astrocytoma grade II, for whom optimal treatment is now controversial. 


\section{References}

1. Karim ABMF, Afra D, Cornu P, et al. Randomized trial on the efficacy of radiotherapy for cerebral low-grade glioma in the adult: European Organization for Research and Treatment of Cancer Study 22845 with the Medical Research Council study BRO4: an interim analysis. Int $J$ Rodiat Oncol Biol Phys 2002; 52: 316-324.

2. Karim ABMF, Maat B, Hatlevoll R, Menten J, et al. A randomized trial on dose-response in radiation therapy of low-grade cerebral glioma: European Organization for Research and Treatment of Cancer (EORTC) Study 22844. Int J Rodiat Oncol Biol Phys 1996; 36: 549. 556.

3. Shaw EG, Arusell R, Scheithauer BW, et al. Prospective randomized trial of low-versus high-dose radiation therapy in adults with supratentorial low-grade glioma: initial report of a North Central Cancer Treatment Group/Radiation Therapy Oncology Group/Eastern Cooperative Oncology Group study. J Clin Oncol 2002; 20: 2267-2276.

4. Berger MS, Deliganis AV, Dobbins J, Keles GE. The effect of extent of resection on recurrence in patients with low grade cerebral hemisphere gliomas. Cancer 1994; 74: 1784-1791.

5. Lote K, Egeland T, Hager B, Stenwig B, Skullerud K, Berg-Johnsen J, Storm-Mathisen I, Hirschberg $\mathrm{H}$. Survival, prognostic factors, and therapeutic efficacy in low.grade glioma: a retrospective study in 379 patients. J Clin Oncol 1997; 15: 3129-3140.

6. Arienti VM, Botturi A, Boiardi A, Broggi G, Collice M, Fariselli L, Zanni D, Botturi M. Adult brain low-grade astrocytomas: survival after surgery and radiotherapy. Neurol SCi 2001; 22: 233-238.

7. Shaw EG, Daumas-Duport C, Scheithauer BW, Gitbertson DT, OFallon JR, Earle JD, Laws ER, Okazaki H. Radiation therapy in the management of low-grade supratentorial astrocytomas. J Neurosurg 1989; 70: 853-861.

8. Bauman G, Lote K, Larson D, Stalpers L, Leighton C, Fisher B, Wara W, MacDonald D, Stitt L, Cairncross JG. Pretreatment factors predict overall survival for patients with low-grade glioma: a recursive partitioning analysis. Int J Radiat Oncol Biol Phys 1999; 45: 923.929

9. Vecht CJ. Effect of age on treatment decisions in low-grade glioma. J Neurol Neurosurg Psychiatry 1993; 56: 1259-1264.

10. Recht LD, Lew R, Smith TW. Suspected low-grade glioma: is deferring treatment safe? Ann Neurol 1992; 31: 431.436 .

11. Korkolopoulou P, Christodoulou P, Kouzelis K, Hadjiyannakis M, Priftis A, Stamoulis G, Seretis A, Thomas-Tsagli E MDM2 and p53 expression in gliomas: a multivariate survival analysis including proliferation markers and epidermal growth factor receptor. Br J Cancer 1997; 75: 1269-78.

12. Sallinen SL, Sallinen P, Haapasalo H, Kononen J, Karhu R, Helen P, Isola J. Accumulation of genetic changes is associated with poor prognosis in grade II astrocytomas. Am J Pathol 1997; 151: 1799-1807. 
13. Wessels PH, Twijnstra A, Kessels AGH, Krijne-Kubat B, Theunissen PH, Ummelen MIJ, Ramaekers FCS, Hopman AHN. Gain of chromosome 7 as detected by in situ hybridization (ISH) strongly correlates with shorter survival in astrocytoma grade 2. Genes Chromosomes Cancer 2002; 33: 279-284.

14. Kleihues P, Cavenee WK, eds. Pathology and genetics of tumors of the nervous system. 2nd ed. Lyon: International agency for research on cancer, 2000.

15. Hopman AHN, Ramaekers FCS (1998) Processing and staining of cell and tissue material for interphase cytogenetics. In: Current protocols in cytometry, Robinson P (ed). New York: John Wiley \& Sons, 1998. Chapter 8.5.1-8.5.2.

16. Hosmer DW, Lemeshow S. Applied logistic regression. New York: John Wiley \& Sons, 2000.

17. Cox D. Regression model and life tables. J R Stat Soc Series B 1972; 34: 187-229.

18. Heesters MAAM, Koudstaal J, Go KG, Molenaar WM. Analysis of proliferation and apoptosis in brain gliomas: prognostic and clinical value. J Neurooncol 1999; 44: 255-266.

19. McKeever PE, Strawderman MS, Yamini B, Mikhail AA, Blaivas M. MIB-1 proliferation index predicts survival among patients with grade II astrocytoma. J Neuropathol Exp Neurol 1998; 57: 931-936.

20. Ito S, Chandler KL, Prados MD, Lamborn K, Wynne J, Malec M, Wilson C, Davis R, Hoshino T. Proliferative potential and prognostic evaluation of low-grade astrocytomas. $J$ Neurooncol 1994; 19: 1.9.

21. Fisher BJ, Naumova E, Leighton CC, Naumov GN, Kerklviet N, Fortin D, Macdonald DR, Cairncross JG, Bauman GS, Stitt L. Ki-67: a prognostic factor for low-grade glioma? Int $J$ Radiat Oncol Biol Phys 2002; 52: 996-1001.

22. Kimmel DW, O'Fallon JR, Scheithauer BW, Kelly PJ, Dewald GW, Jenkins RB. Prognostic value of cytogenetic analysis in human cerebral astrocytomas. Ann Neurol 1992; 31:534. 342.

23. Cianciulli AM, Morace E, Coletta AM, Occhipinti E, Gandolfo GM, Leonardo G, Carapella CM. Investigation of genetic alterations associated with development and adverse outcome in patients with astrocytic tumor. J Neurooncol 2000; 48 :95-101.

24. al-Sarraj S, Bridges LR. p53 immunoreactivity in astrocytomas and its relationship to survival. Br J Neurosurg 1995; 9: 143-149.

25. Kraus JA, Bolln C, Wolf HK, Neumann J, Kindermann D, Fimmers R, Forster F, Baumann A, Schlegel U. TP53 alterations and clinical outcome in low grade astrocytomas. Genes Chromosomes Cancer 1994; 10: 143-149.

26. Sallinen PK, Haapasalo HK, Visakorpi T, Helen PT, Rantala IS, Isola JJ, Helin HJ. Prognostication of astrocytoma patient survival by Ki-67 (MIB-1), PCNA, and S-phase fraction using archival paraffin-embedded samples. J Pathol 1994; 174: 275-282.

27. Kallioniemi OP, Kaltioniemi A, Piper J, Isola J, Waldman FM, Gray JW, Pinkel D. Optimizing comparative genomic hybridization for analysis of DNA sequence copy number changes in solid tumors. Genes Chromosomes Cancer 1994; 10: 231-243. 
28. Arnoldus EP, Wolters LBT, Voormolen JHC, van Duinen SG, Raap AK, van der Ploeg M, Peters ACB. Interphase cytogenetics: a new tool for the study of genetic changes in brain tumors. J Neurosurg 1992, 76: 997-1003

29. Steilen-Gimbel H, Henn W, Kolles H, Moringlane JR, Feiden W, Steudel WI, Zang KD. Early proliferation enhancement by monosomy 10 and intratumor heterogeneity in malignant human gliomas as revealed by smear preparations from biopsies. Genes Chromosomes Cancer 1996; 16: 180-184.

30. Chamberlain MC, Murovic JA, Levin VA. Absence of contrast enhancement on CT brain scans of patients with supratentorial malignant gliomas. Neurology 1988, 38: 1371-1374

31. McCormack BM, Miller DC, Budzilovich GN, Voorhees GJ, Ransohoff J. Treatment and survival of low-grade astrocytoma in adults-1977-1988. Neurosurgery 1992; 31: 636-642.

32. Cheng $Y$, Ng HK, Ding M, Zhang SF, Pang JC, Lo KW. Molecular analysis of microdissected de novo glioblastomas and paired astrocytic tumors. J Neuropathol Exp Neurol 1999; 58: 120-128

33. Leighton C, Fisher B, Bauman G, Depiero S, Stitt L, MacDonald D, Cairncross G. Supratentorial low-grade glioma in adults: an analysis of prognostic factors and timing of radiation. J Clin Oncol 1997; 15: 1294-1301.

34. Krouwer HG, Davis RL, Silver P, Prados MD. Gemistocytic astrocytomas: a reappraisal. J Neurosurg 1991; $74:$ 399-406. 



\section{6}

\section{0q25.3 (DMBT1) copy number \\ changes in astrocytoma grade II and IV}

Wessels PH, Twijnstra A, Kubat B, Ummelen MIJ, Claessen SMH, Sciot R, Merlo A, Ramaekers FCS, Speel EJM, Hopman AHN. Genes Chromosomes Cancer, In press 



\begin{abstract}
In the literature it has been suggested that loss of the 10q25-26 region, including the DMBT1-gene (10q25.3), is correlated with initiation and/or malignant progression of astrocytomas, although the results of the $\mathrm{LOH}$-studies that led to this assumption are not unequivocal. For this reason we compared copy number changes of $10 \mathrm{q} 25.3$ to those of the pericentromeric region $(10 q 12)$ by double-target fluorescence in situ hybridization (FISH) in ten cases of astrocytoma grade II and grade IV each. The same specimens were analysed for copy number changes of chromosome 1, as a marker for polyploidy, and chromosome 7, which is often gained in astrocytomas. Our results show that selective loss of the $10 \mathrm{q} 25.3$ region was present in 2 of 10 specimens in both astrocytoma grade II and grade IV, and occurred only in tumors with polysomy for 10q12. Furthermore, astrocytoma grade II often showed polyploidy for chromosomes 1 , 7 and 10 (8 of 10 specimens). In addition, astrocytoma grade IV frequently exhibited losses of chromosome 10 in a high percentage of nuclei. Although based on a small number of cases the results show that loss of the $10 \mathrm{q} 25.3$ region is uncommon in astrocytoma grade II and mostly coincident with loss of chromosome 10 in grade IV tumors. These data indicate that selective loss of the $10 \mathrm{q} 25.3$ region, including the DMBT1-gene, is not an initiating event in the carcinogenesis of astrocytoma.
\end{abstract}




\section{Introduction}

Astrocytoma is the most frequently occurring primary brain tumor and is classified according to the World Health Organization (WHO) criteria into grades with increasing malignant behavior.' Astrocytoma WHO grade II (A II), or diffuse astrocytoma, occurs in younger patients and often presents with epileptic seizures. Astrocytoma WHO grade IV (A IV), or glioblastoma multiforme, more often causes progressive neurological deficit or raised intracranial pressure, and generally occurs in older patients.

In A II frequent genetic alterations include loss or mutation of the p53 gene ${ }^{2}$ and trisomy for chromosome 7.,4 We recently reported that gain of chromosome 7 is associated with shorter survival of patients with A II. ${ }^{5}$ In A IV the most frequent genetic alteration, occurring in approximately $90 \%$ of cases, involves deletions of chromosome 10. Most A IV have lost an entire copy of chromosome 10, but partial deletions also occur. ${ }^{6}$ Two of these commonly deleted regions in A IV comprise $10 \mathrm{q} 23$, containing the PTEN/MUAC1-gene ${ }^{7.8}$, and 10q25-26, containing the Deleted in Malignant Brain Tumor 1 (DMBT1)-gene. 9

Monosomy for chromosome 10 and selective loss of $10 \mathrm{q} 23$ are uncommon in A II. ${ }^{10-13}$ However, molecular allelotyping has indicated that loss of heterozygosity $(\mathrm{LOH})$ within the10q25-26 region may be associated with initiation of A II and/or malignant progression of A II to A IV. ${ }^{11,14-16}$

The role of the 10q25-26 region in astrocytoma carcinogenesis is, however, questionable. In Table 1 studies in A II and A IV are listed that pay special attention to loss of chromosome 10 and $10 q 25-26 .^{9,11-22}$ This overview demonstrates that selective loss of $10 \mathrm{q} 25-26$ is only detected in a small percentage $(<10 \%)$ of A II. Since these studies were based on microsatellite analyses we cannot exclude that they underestimate the actual frequency of 10q25-26 loss, because A II tissue often consists of non-homogenous areas of tumor and non-neoplastic cells. ${ }^{23}$

The objective of the underlying study was therefore to investigate whether or not physical loss of the $10 \mathrm{q} 25.3$ region can be detected in these tumors by the in situ hybridization (ISH) procedure, and if it this provides a marker for rapid malignant progression of A II to A IV.

For this purpose cell suspensions were prepared from frozen tissue of A II and A IV, and analysed by double-target FISH, using probes for the 10q25.3 and the pericentromeric region $10 \mathrm{q} 12$, allowing the detection of selective $10 \mathrm{q} 25.3$ loss at a single cell level. 
TABLE 1. A summary of molecular cytogenetic studies concerning chromosome 10 with special attention to the $10925-26$ region in astrocytoma grade II and IV of adult patients. Only the two most extensive FISH studies are listed.

\begin{tabular}{|c|c|c|c|c|}
\hline \multicolumn{3}{|c|}{ Deletions of chromosome 10} & \multirow[t]{2}{*}{ Method } & \multirow[t]{2}{*}{ Reference } \\
\hline & $A \|^{\circ}$ & $A I V$ & & \\
\hline Monosomy & $0 / 72$ & & ISH & Hilton et al ${ }^{12}$ \\
\hline Monosomy & & $49 / 64$ & FISH & Amalfitano et al " \\
\hline Monosomy & $0 / 3$ & $23 / 31$ & MA & Kartbom et al." \\
\hline Q-arm & $0 / 3$ & $5 / 31^{*}$ & & \\
\hline p-arm & $0 / 3$ & $7 / 31^{\circ}$ & & \\
\hline Monosomy & & $7 / 30$ & MA & Fults et at 19 \\
\hline p-arm & & $2 / 30^{\circ}$ & & \\
\hline Q25-qter & & $6 / 30$ & & \\
\hline Monosomy & $0 / 33$ & $24 / 49$ & MA & Rasheed et al 15 \\
\hline $\mathrm{q} 25.1$ & $1 / 33$ & $9 / 49$ & & \\
\hline Monosomy & $0 / 7$ & $58 / 64$ & MA & Maier et al 11.20 \\
\hline Q-arm & $1 / 7$ & $2 / 64$ & & \\
\hline Q25.26 & $1 / 7$ & $3 / 64$ & & \\
\hline Monosomy & $3 / 23$ & $103 / 122$ & $M A$ & Ichimura al " \\
\hline Q-arm & $0 / 23$ & $11 / 122^{\circ}$ & & \\
\hline p-arm & $5 / 23$ & $4 / 122^{\circ}$ & & \\
\hline Monosomy & & $0 / 8^{\circ}$ & MA & Fuijsawa et al ${ }^{14}$ \\
\hline $10 q$ & & $5 / 8$ & & \\
\hline 10q25-qter & & $2 / 8$ & & \\
\hline Monosomy & $0 / 4$ & $14 / 24$ & MA & Steck et al ${ }^{16}$ \\
\hline Q-arm & $2 / 4$ & $8 / 24$ & & \\
\hline q25.26 & $2 / 4$ & $1 / 24$ & & \\
\hline DMBT1 & $0 / 5$ & $9 / 39$ & Q.PCR & Mollenhauer et al ${ }^{\circ}$ \\
\hline DMBT1 & $0 / 18$ & $7 / 58$ & $Q \cdot P C R$ & von Deimling et al ${ }^{13}$ \\
\hline DMBT1 & & $8 / 21$ & PCR & Somerville et at ${ }^{n}$ \\
\hline
\end{tabular}

Symbols and abbreviations;

- = frequency of chromosome 10 deletions in astrocytoma grades II (A II) and IV (A IV):

$\mathrm{a}=$ partial deletions of both $10 \mathrm{p}$ and $10 \mathrm{q} ; \mathrm{b}=$ high-grade foci in five secondary glioblastoma; $M A=$ micro-satellite analysis; $Q \cdot P C R=$ quantitative - polymerase chain reaction 


\section{Material and methods}

\section{Tumor specimens}

Frozen specimens of 10 astrocytoma grade II (A II; cases 1 to 10) and 10 astrocytoma grade IV (A IV; cases 11 to 20) were collected from the files of the Pathology Departments of the University Hospitals Maastricht (Netherlands) and Leuven (Belgium). The tumors were derived through stereotactic biopsy (65\%) or resection (35\%) in the period between 1993 and 2001. The A II series consisted of nine fibrillary and one gemistocytic astrocytoma. The group of A IV consisted of nine primary and one secondary (progressive) glioblastoma. Sections with representative tumor tissue were selected by the neuro-pathologist (B.K.) according to the World Health Organization (WHO)- classification. ${ }^{1}$ Progression free and overall survival were assessed from the patients' records.

\section{Ki-67 and P53 immunohistochemistry}

Of the same specimen 5 micron thick paraffin-embedded tissue sections were deparaffinized and pre-incubated in methanol with $0.3 \% \mathrm{H}_{2} \mathrm{O}_{2}$. Antigen retrieval was achieved by incubation with $10 \mathrm{mM}$ citrate buffer $(\mathrm{pH} 6.0)$ in a microwave oven at $700 \mathrm{~W}$ for ten minutes. The sections were incubated with the mouse monoclonal antibody MIB1 directed against Ki-67 (Immunotech S.A. Marseille, France) at a 1:12 dilution, or with the mouse monoclonal antibody DO-7, directed against human P53 protein (Dako A/S, Glostrup, Denmark), at a 1:25 dilution in phosphate buffered saline (PBS) containing $4 \%$ normal goat serum for 60 minutes. After a washing step, biotin-labeled horse antimouse antibody at a 1:200 dilution and avidin-biotin peroxidase complex (Vector Laboratories, Burlingame, CA, US) were applied for 60 and 45 minutes, subsequently. Peroxidase activity was detected using diaminobenzidine in PBS/ imidazole buffer with $0.02 \% \mathrm{H}_{2} \mathrm{O}_{2}$. Tissues known to be negative for $\mathrm{Ki}-67$ and P53 protein were used as control. Positive nuclei were scored in 500 cells in each sample in the areas with the highest immunopositivity. The Ki-67 labeling index (LI) was expressed as the percentage of immunopositive cells from the total cells. Scoring for nuclear P53 staining was done on a four point scale: 0 indicating no staining, + indicating $<5 \%$ positive nuclei, ++ indicating $5 \cdot 20 \%$ positive nuclei, and +++ indicating $>20 \%$ of nuclei with positive staining. 


\section{Double-target FISH}

\section{Isolation of nuclei}

Tumor nuclei were isolated from $30 \mu$ thick sections as described previously. ${ }^{24}$ The sections were digested in $1 \mathrm{ml}$ of $100 \mu \mathrm{g} / \mathrm{ml}$ pepsin (from porcine stomach: $800 \mathrm{U} / \mathrm{mg}$ protein; Sigma St. Louis, MO, USA) in $0.01 \mathrm{M} \mathrm{HCl}$ for 20 minutes at $37^{\circ} \mathrm{C}$. In order to obtain single nuclei the tissue material was resuspended through a thin needle $(21 \mathrm{G})$. $200 \mu \mathrm{l}$ of the cell suspension was cytocentrifuged for 5 minutes at $1200 \mathrm{rpm}$ onto a poly-L-lysine coated slide. The slides were subsequently dehydrated in $70 \%, 96 \%$ and $100 \%$ ethanol.

\section{DNA probes}

Double-color fluorescence in situ hybridization (FISH) was performed using a combination of DNA probes for the $10 \mathrm{q} 25.3$ and the $10 \mathrm{q} 12$ regions. The PAC probe mapping to 10q25.3 (D105209; references 9, 20, 25) was labeled with biotin by nick translation. The 10q12 probe (D10Z1; reference 26) was labeled with digoxigenin. The specificity of these probes were validated on human metaphase preparations, as is shown in Figure 1.

FISH analysis was also performed with a combination of probes for the (sub). centromeric region of chromosome 1 (1q12,pUC 1.77; reference 27), as a marker for ploidy status, and for the alphoid region of chromosome 7 (p7t1; reference 28 ). All probes were hybridized in a mixture containing $2 x$ standard saline citrate (SSC, $\mathrm{pH} 7.0$ ), $50 \%$ formamide, $10 \%$ dextran sulfate and $0.2 \mathrm{mg} / \mathrm{ml}$ herring sperm DNA (hybridization mixture).

\section{Fluoresence in situ hybridization}

Ten microliters of the hybridization mixture was added to the slides under a coverslip. Denaturation was performed at $75^{\circ} \mathrm{C}$ for 4 minutes, followed by hybridization overnight at $37^{\circ} \mathrm{C}$. The following day the slides were washed twice for $5 \mathrm{~min}$ in $50 \%$ formamide, 2 X SSC/ $0.05 \%$ Tween pH 7.0, at $45^{\circ} \mathrm{C}$, and thereafter twice for $5 \mathrm{~min}$ in 2 X SSC/ $0.05 \%$ Tween $\mathrm{pH} 7.0$, at $42^{\circ} \mathrm{C}$, and once for $5 \mathrm{~min}$ in $4 \times \mathrm{SSC} / 0.05 \%$ Tween pH7.0, at room temperature.

The biotinylated probe was detected by rhodamine conjugated to avidin. If necessary this signal was intensified by subsequent incubation with biotinylated goat-anti-avidine and avidine-rhodamine (Vector Laboratories, Burlingame, CA, US). The digoxigenin- 
labeled probe was detected by mouse anti-digoxin monoclonal antibody (Sigma), and (if necessary) the signal was intensified by rabbit-anti-mouse, followed by swine-antirabbit antibodies both conjugated to FITC (Vector Laboratories). The nuclei were counterstained with 4'6-diamino-2-phenylindole (DAPI; Sigma). Fluorescence microscopy was performed using a Leica-DMBRE microscope (Leica Mikroskopie und Systeme GmbH, Wetzlar, Germany) with the appropriate filter sets. All slides were evaluated by two investigators (PW, AH), blinded for the clinico-pathological data. At least 100 nuclei were analysed and aberrations were only scored if present in $>5 \%$ of the nuclei., 5.29 Clustered cells or multinucleated cells were not analysed. Microphotographs were recorded with the In Situ Image System (Metasystems GmbH, Altussheim, Germany) using a black and white CCD camera.

\section{Statistical evaluation}

Patient age and $\mathrm{Ki}-67$ labeling index were correlated to tumor grade using student-T. tests. The prognostic value of tumor grade on survival was analyzed using log-rank tests on Kaplan-Meier curves.

\section{Results}

\section{Clinical data and immunohistochemistry}

The clinical data and immunohistochemical findings are summarized in Table 2. The mean age of A II patients was 40 years (range: 25-54 years) and of A IV patients 59 years (range: $31-75$ years) (student $T$-test, $p<0.01$ ). Fourteen patients were male, and six were female. The mean progression free interval for A II patients was 59 months (range 7. 80 months) and the mean survival interval of A IV patients 8 months (range 2 33 months) (Log-rank; $p=0.002$ ).

Immunohistochemical analysis showed overexpression of P53, with > 5\% positive nuclei, in 7 grade II and in 4 grade IV tumors. The mean Ki-67 labeling index (LI) in A II was 2.9\% (range 0-7\%) and in the A IV $18.7 \%$ (range 9-33\%) (T-test, $\mathrm{p}<0.01$ ). The differences in patient age, clinical course and $\mathrm{Ki}-67 \mathrm{LI}$ further validate the histological classification of A II and A IV samples.

\section{FISH data}

All tumors were analyzed by FISH for copy number changes of the (peri-)centromeric regions of chromosomes $1(1 \mathrm{C}), 7(7 \mathrm{C})$ and $10(10 \mathrm{C})$ and 10q25.3. 
TABLE 2. Clinical data, immunohistochemical data for P53 and $\mathrm{Ki}-67$, and FISH results in astrocytoma grade II (cases 1-10) and grade IV (cases 11-20).

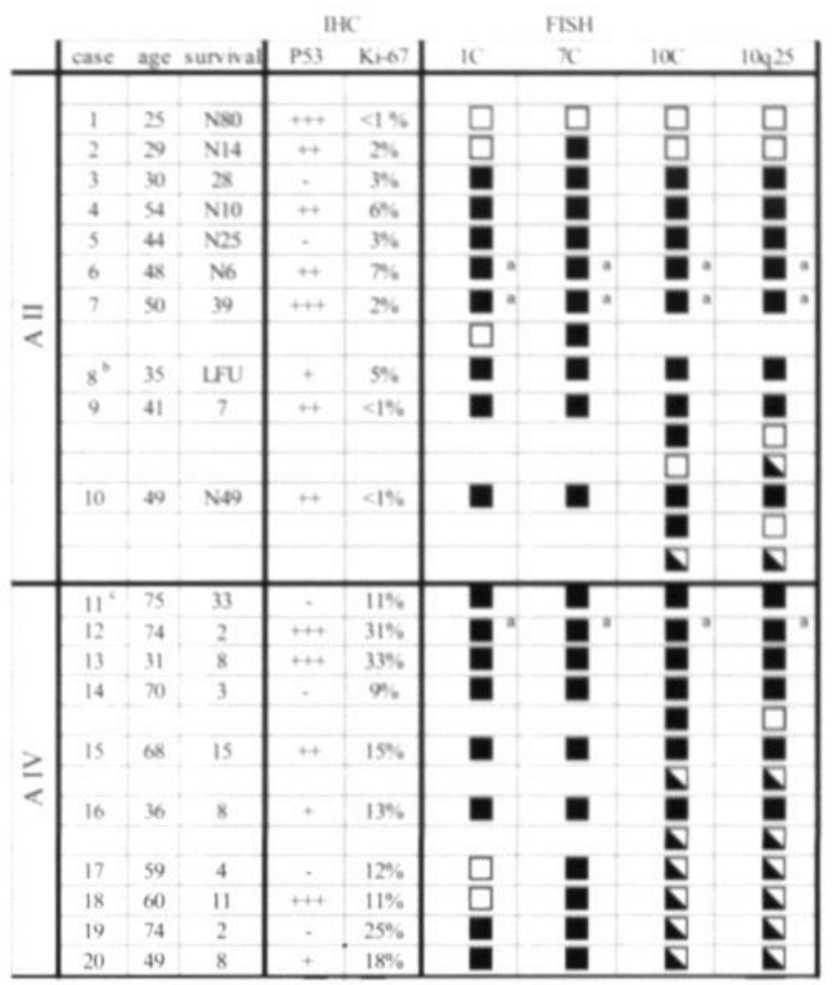

Symbols and abbreviations:

disomy (two signals)

polysomy (three or more signals)

$\mathbf{Q}$ monosomy (one signal)

a = six signals for chromosome 7 , four signals for chromosome 10

b = gemistocytic astrocytoma grade II; $c=$ secondary glioblastoma

$\mathrm{N}=$ no tumour progression at follow-up; LFU = lost to follow-up;

On average $52 \%$ (range $34-100 \%$ ) of the nuclei in A II showed normal (disomic) copy number for all three targets, while this was the case for only $33 \%$ (range 12.52\%) of the nuclei in A IV (T-test, $p=0.04$ ). Table 2 shows that all tumors, with the exception of one A II (case 1), contained one or more populations of nuclei with aberrant chromosome copy numbers.

Polysomies, in particular tri- and tetrasomies for all investigated chromosomes were frequently present in A II ( 8 out of 10 cases). In these 8 A II specimens major cell 

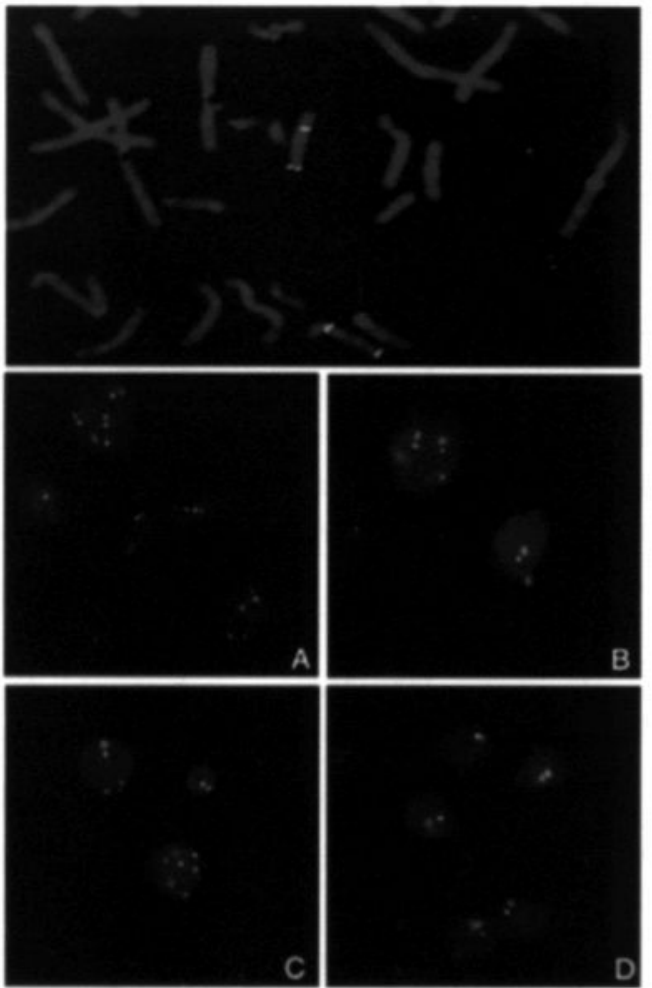

FIGURE 1. Double-FISH on a human metaphase with a $10 \mathrm{q} 23$ probe (red) and $10 \mathrm{q} 12$ (green) pericentromeric ( $\mathrm{C} 10)$ probe, clearly showing the specificity of both probes.

Illustrative cases of different genetic alterations, in:

(A-C) Astrocytomas grade II:

(A) Polysomy for both $10 \mathrm{q} 25.3$ and $10 \mathrm{q} 12$ in case 8 .

(B) Relative loss of $10 \mathrm{q} 25.3$ as compared to $10 \mathrm{q} 12$ in case 9.

(C) Three different alterations in the same tumor: polysomy of $10 \mathrm{q} 12$ and $10 \mathrm{q} 25,3$, monosomy of both regions and selective loss of 10 q25.3 in case 10.

(D) Astrocytoma grade IV with nuclei showing monosomy for 10q12 and 10q25.3 in case 19. 
case 8

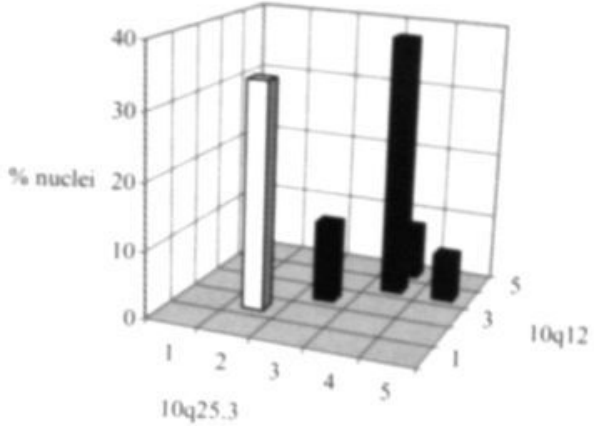

A

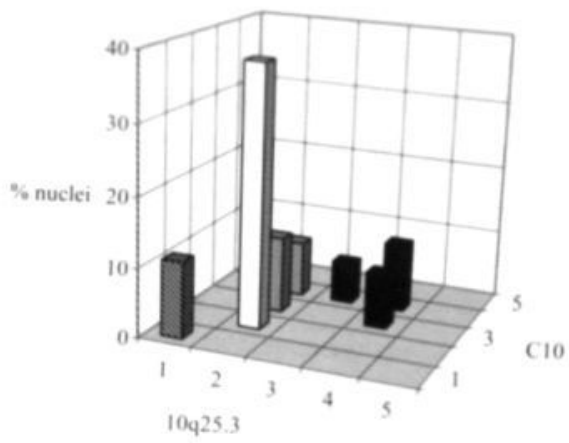

C case 9

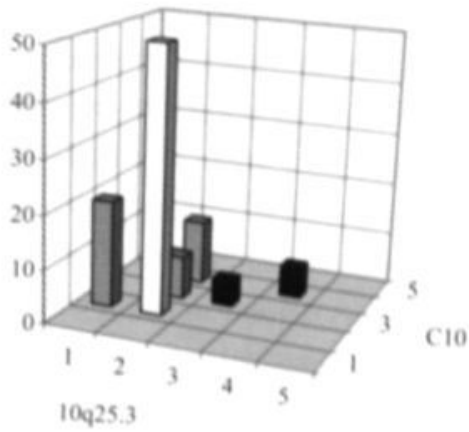

B

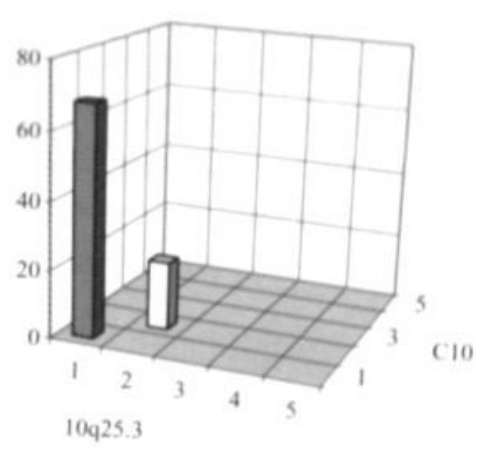

D

FIGURE 2. Bar graphs showing chromosome $10 \mathrm{C}$ and $10 \mathrm{q} 25.3$ copy number distributions of the the $Y$-axis and the percentage of nuclei 1 - The copy-number of $10 \mathrm{q} 25.3$ is shown on the $X$-axis, of $10 \mathrm{C}$ on

$\square$ disomy

polysomy
D monosomy 10

relative loss of $10 \mathrm{q} 25.3$ 
populations showed similar copy numbers for $10 \mathrm{q} 25.3$ and $10 \mathrm{C}$, indicating maintenance of the $10 \mathrm{q} 25.3$ region. As a typical example of this $A$ II tumor cell population the double-target FISH for 10q25.3 and 10C (Figure 1A) and the corresponding frequency distribution of spot numbers (Figure $2 A$ ) are illustrated for case 8 .

In two A II, i.e. cases 9 and 10 in Table 2, cells with selective loss of 10q25.3 were detected, besides the major cell population with polysomic cells (Figure 1B and 2B). In one of these specimens, i.e. case 10 , loss of both $10 \mathrm{C}$ and $10 \mathrm{q} 25.3$ was noticed in $10 \%$ of the nuclei (Figure $1 C$ and $2 C$ ). In 6 of 10 A IV (i.e. cases 14 to 20) loss of both $10 \mathrm{C}$ and $10 \mathrm{q} 25.3$, interpretated as monosomy for chromosome 10, was present. In 5 of these 6 specimens major fractions of cells with monosomy for chromosome 10 and minor fractions with disomic cells were observed (Figure 1D and 2D). Selective loss of $10 \mathrm{q} 25.3$ was present in two A IV specimens, i.e. cases 14 and 20 , that also contained major cell populations with either polysomy or monosomy for chromosome 10, respectively. The only secondary glioblastoma in this series, i.e. case 11 , exhibited a tetraploid clone, without selective loss of 10q25.3.

Since selective loss of $10 \mathrm{q} 25.3$ has been associated with malignant progression of A II, it is noticeable that both A II with selective 10q25.3 loss (i.e. cases 9 and 10) show a low proliferative activity and overexpression of P53. One of these patients (case 9) showed tumor progression within 7 months, while in the other patient (case 10) no tumor progression had occurred after 49 months of follow-up.

\section{Discussion}

In the underlying study we analyzed astrocytomas grade II (A II) and IV (A IV) for $10 \mathrm{q} 25.3 / 10 \mathrm{q} 12$ and chromosome 1 and 7 copy number differences. So far the $10 \mathrm{q} 25.3$ region in astrocytomas has only been studied by molecular allelotyping, which has resulted in contradictory reports in the literature (see below). Therefore we applied the FISH technology, which allows for the detection of copy number changes for this chromosome region at the single cell level. Our results show that the majority of A II often contain gain of all investigated chromosomes, indicating overall polyploidy. A IV often contain loss of chromosome 10, gain of chromosome 7 and/or overall polyploidy. Copy number differences between $10 \mathrm{q} 25.3$ and $10 \mathrm{C}$, indicating selective loss of $10 \mathrm{q} 25.3$, were detected in only a minority of both low- and high-grade astrocytomas.

A deletion mapping study in a large series of A II showed no partial deletions in $10 \mathrm{q} .{ }^{21}$ Maier et al ${ }^{11.20}$ reported partial deletions exclusively targeting to the 10 q25-26 region 
in 3 of 8 low-grade gtiomas, but these lesions comprised two oligodendroglial tumors and only one A II. Finally, Steck et al ${ }^{16}$ found losses of chromosome $10 \mathrm{q}$ in all four cases of A II in their series, which was in two cases limited to 10q25-26. The two latter research groups propose an initiating role for loss of the 10q25-26 region in the development of astrocytomas. "1,16 However the combined results of the deletion mapping studies listed in Table 1 show that selective loss of this subtelomeric region can only be detected in a limited number $(<10 \%)$ of A II cases. A possible explanation for the higher frequency at which we detected a selective loss of 10q25.3 in A II (20\% of the cases) as compared to the previously discussed literature, may be that disomic (normal) cells often constitute a considerable fraction in A II. This admixture with normal cells could explain the underestimation of 10q25-26 loss by molecular deletion mapping procedures.

In both A II with selective loss of 10 q25.3 concomitant major fractions of cells with polysomic copy numbers for the pericentromeric chromosome 10q12 (10C) probe were present. In A IV the results of our FISH analyses are comparable to previous deletion mapping studies. From Table 1 it is obvious that complete loss of chromosome 10 is more frequently detected in A IV than selective loss of 10q25-26. In accord with these observations we found monosomy for chromosome 10 in 6 out of $10 \mathrm{~A}$ IV and selective loss of $10 \mathrm{q} 25.3$ in only 2 out of $10 \mathrm{~A}$ IV. Because of this relatively low frequency of isolated loss of $10 \mathrm{q} 25.3$ as compared to the much higher frequency of the other chromosomal changes occurring in astrocytomas, we suggest that loss of 10q25.3 with the DMBT1 gene occurs as a secondary genetic event in astrocytomas and does not act as an initiating factor in A II carcinogenesis.

However, for two reasons the data should be interpreted with caution. First, small deletions and intragenic mutations could be missed by FISH analysis. Second, very recent data suggest that another tumor suppressor gene on 10q25.3-26.1, encoding an orphan G-protein-coupled receptor GPR26, might be epigenetically silenced in gliomas of different grades. ${ }^{30}$

Some research groups have also suggested that loss of 10q25-26 can be regarded as a marker for progression of A II to A IV (secondary glioblastoma). ${ }^{14,29}$ Hulsebos et al ${ }^{31}$ found that loss of heterozygosity ( $\mathrm{LOH}$ ) of 10q25-26 had occurred in 2 of 7 low-grade astrocytomas that had progressed to A IV, and in 3 of 15 recurrences of A IV. Fujisawa et al ${ }^{14}$ reported LOH of $10 \mathrm{q} 25$-qter in 7 of $8 \mathrm{~A} \mathrm{IV} \mathrm{foci,} \mathrm{an} \mathrm{alteration} \mathrm{that} \mathrm{was} \mathrm{still} \mathrm{not}$ present in the low-grade area of the same tumors. In accord with this assumption we found that one of the A II cases with 10q25.3 loss (case 9) showed rapid malignant progression. In the other A II with 10q25.3 loss (case 10) no tumor progression has occurred after 49 months of follow-up. However, only in this specimen, derived through 
12. Hilton DA, Penney M, Evans B, Sanders H, Love S. Evaluation of molecular markers in lowgrade diffuse astrocytomas: loss of p16 and retinoblastoma protein expression is associated with short survival. Am J Surg Pathol 2002; 26: 472-8.

13. von Deimling A, Fimmers R, Schmidt MC, Bender B, Fassbender F, Nagel J, Jahnke R, et at. Comprehensive allelotype and genetic anaysis of 466 human nervous system tumors. $J$ Neuropathol Exp Neurol 2000; 59: 544-558.

14. Fujisawa $\mathrm{H}$, Kurrer $\mathrm{M}$, Reis RM, Yonekawa $\mathrm{Y}$, Kleihues $\mathrm{P}$, Ohgaki $\mathrm{H}$. Acquisition of the glioblastoma phenotype during astrocytoma progression is associated with loss of heterozygosity on 10q25-qter. Am J Pathol 1999; 155: 387-394.

15. Steck PA, Lin H, Langford LA, Jasser SA, Koul D, Yung WK, Pershouse MA. Functional and molecular analyses of $10 \mathrm{q}$ deletions in human gliomas. Genes Chromosomes Cancer 1999; 24: 135-143.

16. Rasheed BK, McLendon RE, Friedman HS, Friedman AH, Fuchs HE, Bigner DD, Bigner SH. Chromosome 10 deletion mapping in human gliomas: a common deletion region in 10q25. Oncogene 1995; 10: 2243-2246.

17. Amalfitano $G$, Chatel $M$, Paquis $P$, Michiels JF. Fluorescence in situ hybridization study of aneuploidy of chromosomes 7, 10, X, and $Y$ in primary and secondary glioblastomas. Cancer Genet Cytogenet 2000; 116: 6-9.

18. Karlbom AE, James CD, Boethius J, Cavenee WK, Collins VP, Nordenskjold M, Larsson C. Loss of heterozygosity in malignant gliomas involves at least three distinct regions on chromosome 10. Hum Genet 1993; 92: 169-74

19. Fults D, Pedone C. Deletion mapping of the long arm of chromosome 10 in glioblastoma multiforme. Genes Chromosomes Cancer 1993; 7: 173-177

20. Maier D, Comparone D, Taylor E, Zhang Z, Gratzl O, Van Meir EG, Scott RJ, Merlo A. New deletion in low-grade oligodendroglioma at the glioblastoma suppressor locus on chromosome 10q25-26. Oncogene 1997; 15: 997-1000.

21. Ichimura K, Schmidt EE, Miyakawa A, Goike HM, Collins VP. Distinct patterns of deletion on 10p and 10q suggest involvement of multiple tumor suppressor genes in the development of astrocytic gliomas of different malignancy grades. Genes Chromosomes Cancer 1998; 22: 9-15.

22. Somerville RP, Shoshan Y, Eng C, Barnett G, Miller D, Cowell JK. Molecular analysis of two putative tumour suppressor genes, PTEN and DMBT, which have been implicated in glioblastoma multiforme disease progression. Oncogene 1998; 17: 1755-1757.

23. Wessels PH, Hopman AHN, Ummelen MIJ, Krijne-Kubat B, Ramaekers FCS, Twijnstra A (2001) Differentiation between reactive gliosis and diffuse astrocytoma by in situ hybridization. Neurology 2001; 56: 1224-1227.

24. Hopman AHN, Ramaekers FCS. Processing and staining of cell and tissue material for interphase cytogenetics. In: Robinson P (ed) Current protocols in cytometry. New York: John Wiley \& Sons, 1998. Chapter 8.5.1-8.5.2

25. Albarosa R, Colombo BM, Roz L, Magnani I, Pollo B, Cirenei N, Giani C, Conti AM, DiDonato $\mathrm{S}$. Finocchiaro $\mathrm{G}$. Deletion mapping of gliomas suggest the presence of two small regions 
for candidate tumor-suppressor genes in a 17-cM interval on chromosome 10q. Am J Hum Genet 1996; 58: 1260-1267.

26. Devilee P, Kievits T, Waye JS, Pearson PL, Willard HF. Chromosome-specific alpha satellite DNA: isolation and mapping of a polymorphic alphoid repeat from human chromosome 10. Genomics 1988; 3: 1-7.

27. Cooke HJ, Hindley J. Cloning of human satellite III DNA: different components are on different chromsomes. Nucleic Acid Res 1979; 6: 3177-3197.

28. Waye JS, Willard HF. Nucleotide sequence heterogeneity of alpha satellite repetitive DNA: a survey of alphoid sequences from different human chromosomes. Nucleic Acids Res 1987; $15: 7549-7569$.

29. Jansen MP, Hopman AHN, Haesevoets AM, Gennotte IA, Bot FJ, Arends JW, Ramaekers FCS, Schouten HC. Chromosomal abnormatities in Hodgkin's disease are not restricted to Hodgkin/Reed-Sternberg cells. J Pathol 1998; 185: 145-52

30. Boulay IL, Maier D, Labuhn M, Jones, G, Merlo A. The 10q25.3-26.1 gene encoding the orphan $G$ protein-coupled receptor GPR26 is epigenetically silenced in human gtiomas. Proc Annu Meet Am Assoc Cancer Res 2003; 44: 1395.

31. Hulsebos TJM, Oskam NT, Troost D, Leenstra S, Bijleveld EH. Dynamics of genetic alterations associated with glioma recurrence. Genes Chromosomes Cancer 1998; 23: 153 . 158.

32. Salvati M, Cervoni L, Artico M, Caruso R, Gagliardi FM. Long-term survival in patients with supratentorial glioblastoma. J Neurooncol 1998; 36: 61-64 



\title{
7
}

\section{Summary}

\section{Samenvatting}

\section{Publications}

\author{
Dankwoord
}

\section{Curriculum vitae}




\section{Summary}

Astrocytoma grade II (A II), or low-grade diffuse astrocytoma, is a primary brain tumor that in particular occurs in young adults with an estimated incidence between $0,5 \cdot 1,0$ per 100.00 persons/year. A II are histological characterized by an increased cellularity and nuclear atypia of astrocytes, the star-shaped supporter cells of the central nervous system. A II often have an indolent behavior only causing medical controllable epileptic seizures. However, because of the diffuse infiltration of normal brain which makes total resection impossible, the majority will ultimately progress to high-grade astrocytoma, i.e. astrocytoma grade III and IV (A III/ A IV). The interval to malignant progression of A II is highly variable and not reflected by histological features. Prognostic parameters to identify the subgroup of rapid progressive A II are therefore essential for optimizing treatment strategy.

Malignant progression of astrocytomas is accompanied by an accumulation of genetic alterations in the tumor-DNA and an increased proliferation activity. On bases of cytogenetic studies different 'genetic pathways' have been described, one pathway leads to the formation of primary (or de novo) A IV and a second pathway leading to A II and ultimately to secondary (or progressive) A IV.

Cytogenetic studies in astrocytomas have in particular been focused on grade III and IV astrocytomas, and less frequently on A II. The most frequent reported alteration in A II is loss or mutation of the p53 tumor suppressor gene, which probably does not correlate with the clinical behavior of the tumor. Other cytogenetic alterations have been less frequently reported in A II, due to limitations of the cytogenetic techniques used and due to contamination of normal cells that are often present in A II. Moreover the clinical relevance of cytogenetic analysis in A II is still unclear.

The in situ hybridization (ISH) -assay allows the detection of structural chromosomal aberrations at a single cell level and is therefore particularly suited for analysis of A II. We applied this technique on routinely processed tissue samples and determined whether the detection of chromosomal aberrations is of potential diagnostic and prognostic value in A II.

CHAPTER 1 contains a general introduction on gliomas and astrocytomas and in CHAPTER 2 the studies on prognostic parameters and current treatment strategies in astrocytoma grade II are reviewed. Most of these studies are retrospective and difficult to interprete due to selection bias and because most studies also include other variants of low-grade gliomas. From these studies patient age at diagnosis appears as the single 
consistent unfavourable prognostic parameter, and patient age is therefore decisive for current treatment strategies. For patients over 35 years of age an aggressive treatment, comprising tumor resection and radiotherapy, is propagated. For patients under 35 years of age the effectiveness of such an approach has not been proven and for these patients the usefulness of histological confirmation by stereotactic biopsy is often doubted. A major cause for controversy with regard of optimal treatment of A II are limitations of the histological classification of these tumors. First, routine histology tends to underestimate tumor grade due to histological heterogeneity of astrocytomas. Particularly in small stereotactic samples differentiation between A II and reactive gliosis, a proliferation of astrocytes in response to non-neoplastic neurological diseases, is difficult. Second, slow and fast-progressive A II cannot be distinguished on bases of their histological features. Previous studies suggest that the Ki-67 proliferation marker may predict malignant progression of A II, however the prognostic value of cytogenetic markers is largely unknown.

CHAPTER 3 describes the use of the molecular cytogenetic technique in situ hybridisation (ISH) for the detection of chromosomal aberrations in small stereotactic samples with an inconclusive histological diagnosis, in which the neuro-pathologist was unable to differentiate between astrocytoma and reactive gliosis. ISH analysis in thirtheen of these inconclusive cases was performed with probes for chromosome 1, 7 and 10. The probe for chromosome 1 is a general marker for aneuploidy, while gain of chromosome 7 and loss of chromosome 10 have often been implicated in astrocytoma carcinogenesis. In four of the inconclusive cases chromosomal aberrations were detected, in particular gain of chromosome 7. Similar aberrations were present in samples with proven A II and absent in samples with non-neoplastic reactive gliosis. Three of the four cases with chromosomal aberrations in the initial biopsy showed rapid malignant progression. Our data indicate that ISH has additional diagnostic value to detect neoplastic cells in stereotactical biopsies of patients suspected of diffuse astrocytomas in which routine microscopy is inconclusive.

CHAPTER 4 describes the prognostic value of chromosomal aberrations in A II, as detected by ISH. A series of 47 A II were investigated for numerical aberrations of chromosomes 1,7 and 10 . Our result show that more than half of the specimen contained aneusomies, in particular tri and tetrasomies. These chromosomal aberrations always involved chromsome 7. A clear correlation was present between the presence of nuclei with aneusomy for chromosome 7 and shorter survival of A II patients. The fact that similar aberrations for chromosome 7 were not detected in 
reactive gliosis, contradicts the findings of previous karyotyping studies with trisomy 7 in non-neoplastic brain tissue. In this series monosomy for chromosome 10 was present in two of the samples. These samples showed a rapid malignant clinical course, which suggests that the presence of monosomy 10 in histological A II is due to a sampling error from A IV.

CHAPTER 5 compares the prognostic value of cytogenetic and biological parameters versus the prognostic value of clinical parameters in the same series of A II. The median survival interval for patients with A II was 90 months. On multivariate analysis independent prognostic parameters for shorter survival were patient age > 35 years of age, a $\mathrm{Ki}-67$ protiferation index > $1 \%$ and the presence of chromosomal aberrations as detected by ISH. The median survival interval for A II with both a high $\mathrm{Ki}-67$ proliferation index and aneusomy was 40 months, as compared to 140 months for tumors without this unfavorable combination. In particular in young patients, for whom treatment strategy is controversial, the detection of these parameters can clearly identify A II with rapid matignant progression. This is in our view an argument not to defer biopsy in young patients with radiological suspicion of A II.

CHAPTER 6 focuses on the 10q25.3 region, where the Deleted in Malignant Brain Tumor (DMBT1)- candidate tumor suppressor gene is located that might be important in development and/ or malignant progression of A II. The role of this region has been suggested by loss of hetrozygosity ( $\mathrm{LOH}$ )-analysis, however the evidence that led to this assumption is questionable. A series of A II and A IV were investigated by ISH with probes for the 10q25.3 and the pericentromeric region of chromosome 10. Only in a minority of both A II and A IV relative loss of the 10q25.3 region was detected. These samples always showed other chromosomal aberrations, in particular overall aneuploidy. These data indicate that loss of the 10q25.3 region is not an initiating event in astrocytoma carcinogenesis.

IN CONCLUSION, in situ hybridization has additional diagnostic and prognostic value to routine microscopy of A II. Chromosomal aberrations such as trisomy of chromosome 7 and aneuploidy are present in the majority of A II, and correlate with the clinical course. In future the detection of these and other cytogenetic alterations will help optimizing treatment strategy for astrocytoma patients. 
112 


\section{Samenvatting}

Gliomen zijn de meest frequent voorkomende primaire hersentumoren, en worden al naar gelang celtype onderverdeeld in astrocytomen, oligodendrogliomen en ependymomen. Astrocytoom graad II (A II), ook wel laaggradig diffuus astrocytoom genoemd, is een hersentumor die met name voorkomt bij jong volwassen patienten met een incidentie van 0.5-1.0 per 100.000 personen per jaar.Een A II wordt gekenmerkt door een toegenomen celdichtheid en kernatypie van astrocyten (de stervormige steuncellen van het centraal zenuwstelsel). Doordat het A II zich diffuus uitbreidt tussen het gezonde hersenweefsel is complete neurochirurgische resectie zelden mogelijk. Dit is een van de oorzaken voor de huidige behandelingscontroverse voor patiènten met A II.

Een deel van de A II vertoont geen of nauwelijks groei en kan zo jarenlang geen klachten veroorzaken, of alleen mecicamenteus te behandelen epileptische insulten. Echter, A II kan ook een snelle, maligne progressie doormaken naar het hooggradig astrocytoom (astrocytoom graad III, A III, of graad IV, A IV). Vanwege dit onvoorspelbare beloop is de behandelingsstrategie bij A II discutabel, en is het zoeken naar prognostische parameters van belang om de behandeling in de toekomst te kunnen optimaliseren.

De maligne progressie van A II gaat gepaard met een toename van celproliferatie en een opeenstapeling van genetische afwijkingen in het tumor-DNA. In tegenstelling tot A IV, zijn bij A II weinig studies naar deze cytogenetische afwijkingen verricht. De enige afwijking die vaak in A II gerapporteerd wordt is verlies of mutatie van het p53-gen, een afwijking die waarschijnlijk niet gecorreleerd is aan het klinisch beloop. Verder zijn weinig genetische afwijkingen in A II beschreven, hetgeen verklaard kan worden door de beperkingen van de gehanteerde cytogenetische technieken en doordat in A II vaak normale, niet-maligne, cellen voorkomen die de gevoeligheid van cytogenetische analyse negatief kunnen beïnvloeden.

De in situ hybridisatie (ISH) techniek is zeer geschikt voor het aantonen van chromosomale afwijkingen in A II, omdat deze techniek niet wordt beinvloed door de aanwezigheid van normale cellen. Daarom werd onderzocht of de detectie van chromosomale afwijkingen in A II met ISH diagnostische en prognostische waarde heeft, hetgeen uiteindelijk kan leiden tot een optimalere behandeling van A II patienten.

In HOOFDSTUK 1 wordt een korte inleiding over gliomen en astrocytomen gegeven, waarna in HOOFDSTUK 2 een overzicht van literatuurstudies wordt gepresenteerd die 
de prognostische parameters in A II hebben onderzocht. De meeste van deze studies zijn retrospectief en moeilijk te interpreteren ten gevolge van selectiebias en doordat deze studies naast A II vaak ook andere varianten van laaggradige gliomen bevatten. Uit deze studies blijkt wel dat de leeftijd van de patiënt ten tijde van de diagnose de enige consistente prognostische parameter was voor het beloop van A II. Daarom is de leeftijd van de patiënt ook bepalend voor de huidige behandelingsstrategieën. Voor patiënten ouder dan 35 jaar wordt een intensieve behandeling, bestaande uit tumorresectie gevolgd door radiotherapie, geadviseerd. Voor jongere patiënten is de effectiviteit van deze interventies nooit bewezen. Ook bestaat er ernstige twijfel of het nemen van een stereotactische biopsie wel zinvol is bij jonge patiënten met een radiologische verdenking voor A II, aangezien histologische bevestiging het beleid toch niet verandert.

De behandelingscontroverse voor jonge patiënten met A II wordt veroorzaakt door beperkingen in de histologische gradering. Ten eerste wordt de tumorgraad van astrocytomen vaak te laag ingeschat door de histologische heterogeniteit van astrocytomen. Daardoor is vooral in een kleine biopsie het onderscheid tussen A II en reactieve gliose, een verlittekening die bij tal van niet-maligne neurologische aandoeningen kan voorkomen, vaak niet te maken. Ten tweede kan op basis van het histologisch beeld geen onderscheid worden gemaakt tussen langzaam-groeiend en snel-groeiende progressieve A II. Eerdere studies hebben gesuggereerd dat aanvullende immuunhistochemische kleuring voor de proliferatiemarker Ki-67, de maligne progressie van A II wel kan voorspellen. Of het aantonen van specifieke genetische afwijkingen in A II ook prognostische waarde heeft, is nooit uitgebreid onderzocht.

HOOFDSTUK 3 beschrijft het nut van de in situ hybridisatie (ISH) techniek met behulp van het aantonen van chromosomale afwijkingen in stereotactisch biopsie-materiaal met een niet-conclusieve histologische diagnose, waarbij de patholoog niet kon differentiëren tussen A $\|$ en reactieve gliose. Dertien van deze gevallen werden onderzocht met ISH, waarbij gebruik werd gemaakt van probes voor de chromosomen 1 , 7 en 10. Chromosoom 1 is een algemene marker voor ploidie-status, terwijl winst van chromosoom 7 en verlies van chromosoom 10 worden verondersteld een rol te spelen bij de maligne progressie van astrocytomen. In 4 van de 13 niet-conclusieve gevallen waren chromosomale afwijkingen aanwezig, met name winst voor chromosoom 7. Deze afwijkingen waren aanwezig in controlemateriaal met eenduidige A II, maar afwezig in reactieve gliose. Deze studie toont het nut van cytogenetische analyse middels ISH van stereotactisch biopsiemateriaal met een niet-conclusieve histologische diagnose. 
In HOOFDSTUK 4 wordt de prognostische waarde van chromosomale afwijkingen, gedetecteerd met ISH, bestudeerd. Hiervoor is een serie van 47 gevallen met A II onderzocht met probes voor de chromosomen 1, 7 en 10. In meer dan de helft van de tumoren waren chromosomale afwijkingen aanwezig, waarbij in alle gevallen chromosoom 7 numerieke afwijkingen vertoonde. Een duidelijke correlatie werd gevonden tussen een hoog percentage kernen met afwijkingen voor chromosoom 7 en een kortere overleving van de A II patiènten. Twee tumoren met verties van chromosoom 10 vertoonden de sneiste maligne ontaarding.

In HOOFDSTUK 5 is de prognostische waarde van deze cytogenetische parameters vergeleken met de prognostische waarde van klinische en biologische parameters in dezelfde A II serie. De mediane overleving van A II patiènten was 90 maanden. Na multivariate analyse bleken 3 onafhankelijke prognostische parameters te wijzen op een kortere overleving: 1) leeftijd van de patient > 35 jaar, 2) de Ki-67 proliferatieindex > 18 en 3) de aanwezigheid van chromosomale afwijkingen. De mediane overleving van patiènten met een hoge $\mathrm{Ki}-67$ index en chromosomale afwijkingen was 40 maanden, vergeleken met een mediane overleving van 140 maanden van patienten met A II zonder deze ongunstige combinatie. Vooral bij jonge patienten blijkt dat met behulp van de proliferatie en genetische markers een subgroep snel-progressief verlopende A II kan worden geidentificeerd. Wij concluderen dat dit een argument kan zijn om een stereotactische biopsie bij jonge patiènten met een radiologische verdenking van A II niet uit te stellen.

In HOOFDSTUK 6 wordt de 10q25.3 regio bestudeerd, waar het DMBT-1 gen is gelokaliseerd. Dit gen speelt mogelijk een rol bij het ontstaan en/ of de maligne progressie van A II. Deze rol is gesuggereerd na genetische analyse middels de loss of heterozygosity $(\mathrm{LOH})$-techniek, waarvan de resultaten echter niet eenduidig waren. Daarom onderzochten wij zowel A II als A IV met een probe voor de 10q25.3 regio, gecombineerd met een probe voor de centromeer regio van chromosoom 10, beiden gedecteerd met ISH, hetgeen als voordeel heeft dat de analyse op individuele tumorcellen uitgevoerd kan worden. Relatief verties van de 10q25.3 werd slechts in enkele gevallen van A II en A IV gevonden. Deze tumoren bevatten ook altijd andere genetische afwijkingen, met name polyploidie, hetgeen suggereert dat verlies van de $10 q 25.3$ regio geen initiërende rol in de carcinogenese van A II speelt.

CONCLUSIE: de cytogenetische ISH-techniek heeft een aanvullende diagnostische en prognostische waarde in de routine diagnostiek van A II. Chromosomale afwijkingen 
zoals trisomie van chromosoom 7 en polyploidie komen vaak voor in A II, en lijken te correleren met het klinisch beloop. Het implementeren van cytogenetische technieken in de routine diagnostiek zal in de toekomst kunnen bijdragen tot het verbeteren van de behandeling voor A II patiënten. 


\section{Publications}

Schijns OE, Kurt E, Wessels PH, Luijckx GJ, Beuls EAM. Intramedullary spinal cord metastasis as a first manifestation of a renal cell carcinoma: report of a case and review of the literature. Clin Neurol Neurosurg 2000 Dec;102(4):249-254.

Wessels PH, ter Berg JW, Spincemaille GH, Dippel DW. Treatment of cerebellar hematoma in The Netherlands. Cerebrovasc Dis 2001;11:190-194

Wessels PH, Hopman AHN, Ummelen MIJ, Krijne-Kubat B, Ramaekers FCS, Twijnstra A. Differentiation between reactive gliosis and diffuse astrocytoma by in situ hybridization. Neurology. 2001; 56:1224-1227.

Wessels PH, Twijnstra A, Ummelen MIJ, Krijne-Kubat, Ramaekers FCS, Hopman AHN. Gain of chromosome 7, as detected by in situ hybridization, strongly correlates with shorter survival in astrocytoma grade 2. Genes Chromosom Cancer 2002; 33, 279-284.

Wessels $\mathrm{PH}$, de Jong $\mathrm{M}$. Cauda equina syndrome due to long-standing ankylosing spondylitis. Ned Tijdschr Geneeskd 2003; 147: 248.

Trip J, Wessels PH, Spaans F. Postsurgical pain and weakness in the shoulder-arm region; iatrogenic or not? Ned Tijdschr Geneesk; in press.

Wessels PH, Hopman AHN, Krijne-Kubat B, Kessels AGH, Hoving EW, Ummelen MIJ, Ramaekers FCS, Twijnstra A. Proliferation and aneusomy predict survival of young patients with astrocytoma grade II. Br J Cancer 2003; 89: 128-134.

Wessels PH, Weber WEJ, Raven G, Ramaekers FCS, Hopman AHN, Twijnstra A. The dilemma of supratentorial astrocytoma grade II: biological parameters and clinical course. The Lancet Neurology; 2003: 2: 395-403.

Wessels PH, Twijnstra A, Kubat B, Ummelen MIJ, Claessen SMH, Sciot R, Merlo A, Ramaekers FCS, Speel EJM, Hopman AHN. Chromosome 10q25.3 (DMBT1) and 10q12 copy number changes in astrocytoma grade II and IV.

Genes Chromosomes Cancer; in press. 



\section{Dankwoord}

Dit jaar heeft tot nu voor mij twee hoogtepunten gehad, die op het eerste gezicht nogal verschillen, maar bij nadere bestudering overeenkomsten vertonen. Het eerste hoogtepunt was het fietsen van de tocht 'La Marmotte' . Hierbij werden verschillende Alpenreuzen overgefietst, zoals de Gallibier en Alpe d'Huez, waarbij ik in tegenstelling tot 2002 niet ben afgestapt. Dit eerste hoogtepunt werd langzaam bereikt, echter snel vergeleken met het tweede hoogtepunt, namelijk het afronden van dit onderzoek.

Dit tweede hoogtepunt was nooit mogelijk geweest zonder de steun van de ploegleiders, ploeggenoten, mecanichiens, de bevoorradingswagens, supporters, en de haptonoom.

Professor dr. Frans Ramaekers, onvervangbaar bij het structureren van dit onderzoek, het aanvragen van de KWF-beurs, en het prepareren van de publicaties.

Professor dr. Jaap Troost, die me voor de opleiding neurologie en dit onderzoek gescout heeft, en steeds betrokken was bij de voortgang.

Dr. Anton Hopman, die met zijn cytogenetische expertise en kritische vragen het enthousiaste brein achter dit onderzoek is, en daardoor zelf soms ook van astrocytomen hoofdpijn heeft gekregen.

Dr. Albert Twijnstra, mede-scout, bedankt voor de onmisbare hulp bij het bijeen krijgen van onze serie A II's en begeleiding bij de eerste wetenschappelijke presentaties.

De overige leden van 'de glioomgroep': Dr. Bela Kubat (patholoog) en drs. ir. Fons Kessels (epidemioloog en statisticus). Ook de leden van het eerste uur: Dr. Gerard Freling (patholoog) en Dr. Marcel Herpers (neurochirurg).

Alle medewerkers van de Moleculaire Celbiologie, Universiteit Maastricht, vooral Monique Ummelen en Sandra Claessen, dank voor het uitvoeren en de hulp bij veel van de experimenten. Dr. Ernst-Jan Speel, voor de vruchtbare discussies over hoofdstuk 6. Francien Teng, voor haar organisatorische ondersteuning, en Wiel Debie, voor de computer-ondersteuning.

Alle collegae van de afdeling Neurologie van het academisch ziekenuis Maastricht, met name Dr. Robert van Oostenbrugge, voorganger bij het ISH onderzoek, en

Dr. Wim Weber, inspirator bij het tweede hoofdstuk. 
Medewerkers van de afdeling Pathologie van het academisch ziekenhuis Maastricht, met name Jan Smeets, voor de hulp met de immuunhistochemische kleuringen.

De collegae van elders die hebben geholpen met materiaal en ideëeen:

Heerlen: Dr. P. Theunissen (patholoog), Dr. P. Koehler (neuroloog).

Enschede: Dr. R. de Vos (patholoog). Nijmegen: Dr. P. Wesseling (patholoog).

Zwolle: Dr. W . du Bois (radiotherapeut).

Groningen : Dr. E. Hoving en Prof. dr. JJ. Mooij (neurochirurgen).

Leuven (B): Prof. dr. R. Sciot (patholoog), Dr. J. Menten (oncoloog)

Voor de 10q25.3 probe: $\mathrm{Dr}$. A. Merlo, afdeling moleculaire neuro-oncologie, Basel (Zw).

De Nederlandse Kankerbestrijding, het Koningin Wilhelmina Fonds, Amsterdam, voorhet financieel mogelijk maken om een onderzoeksjaar te doen.

Voor de omslag: Rogier Trompert en Nathatie Jansen (Trompert Medical Art): prachtfoto en prachtomslag!.

De paranimfen: Huib Rutten en Anton de Louw. Anton en Pascale gaven samen ook goede adviezen voor de lay-out.

Mijn ouders, oom Jaap en tante Ineke, en vooral Nienke, dank voor jullie aanmoedigingen.

Truus, die steeds op lenige wijze het toetsenbord wist te ontwijken. 


\section{Curriculum vitae}

De schrijver van dit proefschrift werd geboren op 11 juni 1970 te Bitthoven. In 1988 werd het VWO van het Sint Bonifatiuscollege in Utrecht gevolgd door de studie Geneeskunde aan de Rijksuniversiteit Groningen. Tijdens het doctoraalexamen, afgerond in 1993, werd een keuzeonderzoek verricht getiteld 'Spierkrachtmeting bij kinderen met de handdynamometer', onder supervisie van Prof. Dr. H.J.G.H. Oosterhuis, neuroloog. Nadien werden de co-assistentschappen gevolgd in het Sint Elisabeth hospitaal, Curaçao, Nederlandse Antillen. Na het artsexamen in 1995 werkte hij als arts-assistent neurologie in het academisch ziekenhuis Groningen en het Sint Clara ziekenhuis te Rotterdam, en als Senior House Officer Cardiology in het Freeman hospital in Newcastle upon Tyne, UK. In januari 1997 trad hij in dienst als AGNIO Neurologie in het academisch ziekenhuis te Maastricht, waar onder begeleiding van $\mathrm{Dr}$.

A. Twijnstra werd gestart met dit onderzoek. In november 1998 werd begonnen met de opleiding neurologie in het Maasland ziekenhuis te Sittard (B-opleider: Dr. H.W.A.M Anten), waarna vanaf november 1999 de opleiding werd voortgezet in Maastricht (opleider: Prof. Dr J. Troost). Gedurende 1 jaar (mei 2000-2001) was hij werkzaam op het in situ hybridisatie laboratorium (Dr. A.H.N. Hopman) van de vakgroep Moleculaire Celbiologie (Prof. Dr F. C.S. Ramaekers), wat mogelijk werd gemaakt door een beurs van het Koningin Withelmina Fonds. In november 2004 hoopt hij de opleiding tot neuroloog af te ronden. 

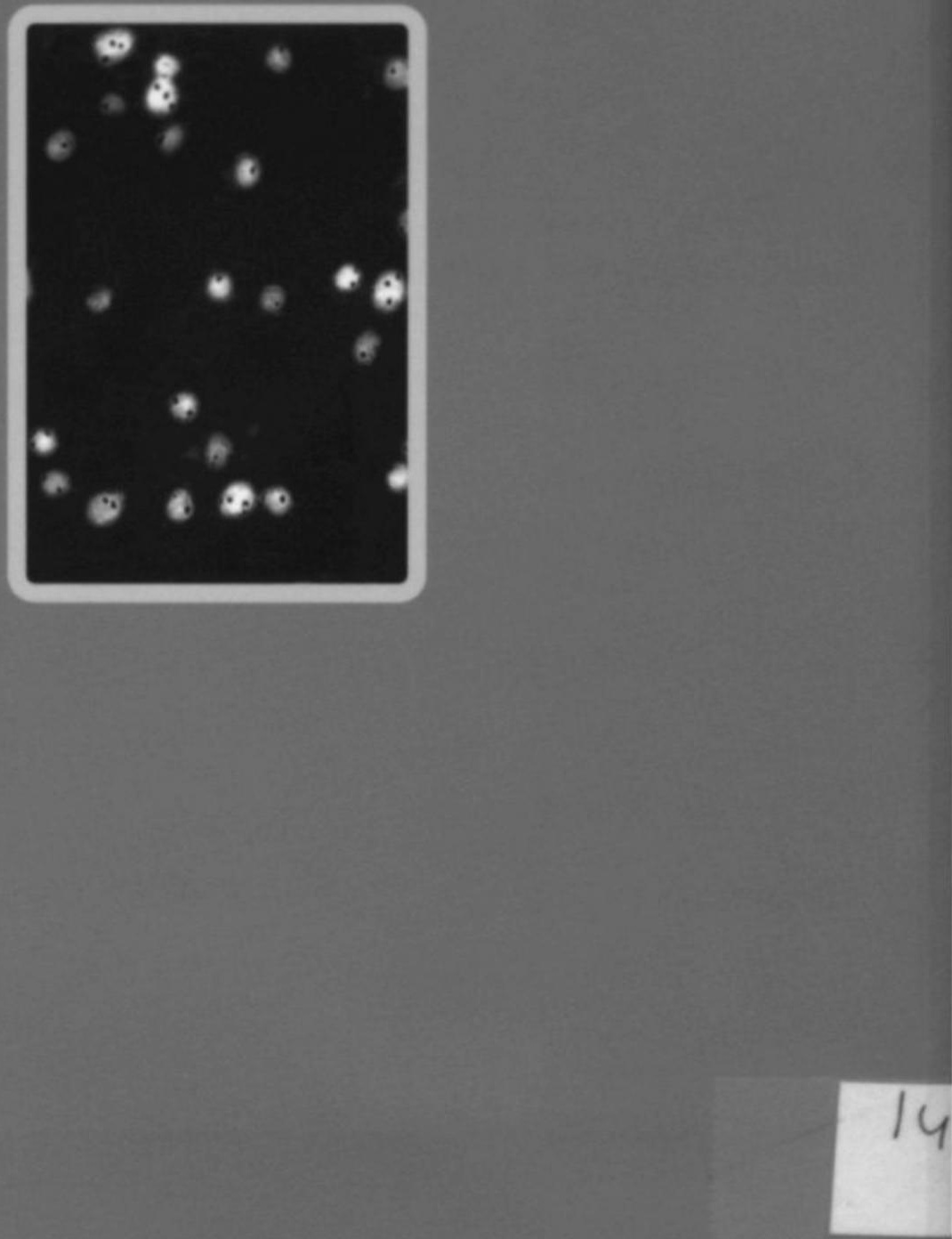